\title{
Water Resources Professional's Outreach Notebook Ground Water Grade Level 6-8
}

by Stephen J. Vandas

U.S. GEOLOGICAL SURVEY

Open-File Report 94-73

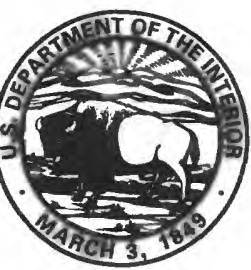




\section{PROJECT INTENT}

The intent of this project is to have individuals who are employed in a job related to water resources discuss their knowledge, experiences, and careers in water resources with students. For the purpose of this notebook, the title Water Resources Professional (WRP) includes individuals employed as hydrologists, engineers, hydrologic technicians, municipal-water and wastewater-treatment operators, etc. Thus, anyone employed in a scientific field relating to water resources can be considered a WRP.

This notebook provides five lesson plans developed to help instructors and WRPs discuss the subject of ground water with students in grades 6-8. This notebook is designed to facilitate a working relationship between educational instructors (classroom teachers, Girl or Boy Scout leaders, 4-H counselors, etc.) and WRPs. Providing complete lesson plans allows the WRP to prepare for the educational visit in less time.

\section{PHILOSOPHY}

Educating today's youth concerning the science of water resources should not be the sole province of educational instructors. Water Resource Professionals can provide a valuable service by sharing technical knowledge of water resources with students and instructors. Meeting and talking with a WRP can help students make a connection with science. Many students view a WRP in a stereotypical manner; a white male wearing dark-rimmed glasses, a thin tie, and a white lab coat. By making a presentation at an educational event, a WRP is able to negate this stereotypical view. Owing to their professional experiences, a WRP can credibly apply water resources science to real-life situations. Helping students to realize that the information they are learning has important applications in the "real" world is a crucial educational step.

\section{USING THE NOTEBOOK}

This notebook is divided into three sections: WRP Section, Instructor Section, and Appendix. The WRP Section includes all necessary information for the WRP's part of the educational event, some presentation tips that provide information and ideas for presenting to students in grades 6-8, and lesson plan evaluation forms. The Instructor Section includes all necessary information for the instructor's part of the educational event. The Appendix includes additional ground-water educational activities and a list of selected references that the WRP can provide to the instructor upon request. Also included is information about ordering and specifications for plastic ground-water models that are used in one of the lesson plans.

The five lesson plans provided in this notebook are the basis for the educational event to be taught by an instructor and a WRP. A lesson plan outline, including an explanation of each part of the lesson plan, is located on page $\mathrm{W}-4$.

To accomplish the activity part of the WRP lesson plan, certain materials are required. Therefore, the class should be limited to no more than 10 working groups with a maximum of 4 students to a group. A listing of the materials for each lesson plan is included in both the Instructor and WRP Sections. The lesson plans were developed by a nationwide team of practicing instructors, curriculum-development specialists, and water-resources specialists.

\section{BEGINNING THE EDUCATION PROCESS}

In most instances, an instructor will request that a WRP make an educational visit. During the initial contact with the instructor, the WRP will discuss the program and then send the instructor a copy of the Instructor Section of this notebook. The instructor is to read the Instructor Section and then contact the WRP to identify the lesson plan to be taught and the date for the educational visit. Lesson plan selection is made from the lesson plan summaries provided in the Instructor Section. The instructor completes the Instructor Information Form (located in the Instructor Section, p. I-4) and mails it to the WRP. Upon receiving the Instructor Information Form, the WRP contacts the instructor to verify the information and clarify responsibilities. Part of this communication will include addressing the items listed on the WRP Checklist. A list of responsibilities is included in both the Instructor and WRP Sections. The WRP Checklist is 
Title: WATER OUR VITAL RESOURCE

Publisher: Oregon Museum of Science and Industry

Copyright: $\mathrm{N}$

Applicable Area: State: $\mathbf{Y}$ Region: $\mathbf{Y}$ National: $\mathbf{Y}$

Type of Educational Material:

Curriculum materials:

Demonstrations:

Projects, games:

$\mathbf{Y}$

$\mathbf{Y}$

$\mathbf{Y}$

Activities:

Teachers Guide:

Student Guide:

$\mathbf{Y}$
$\mathbf{Y}$
$\mathbf{Y}$

Other materials: None

Order From:

Name: $\quad$ Oregon Museum of Science and Industry

Address: $\quad 4015$ S.W. Canyon Road

City/State: Portland, OR 97221

Telephone: (503) 222-2828

Title: WATER POLLUTION AND ENVIRONMENTAL STUDIES

Publisher: Environmental Protection Agency

Copyright: $\mathbf{N}$

Applicable Area: State: $\mathbf{Y}$ Region: $\mathbf{Y}$ National: $\mathbf{Y}$

Type of Educational Material:

Curriculum materials:

Demonstrations:

Projects, games:

Other materials: Field trip guide

Y Activities: $\quad$ Y

Y Teachers Guide: $\quad$ Y

Y Student Guide: $\quad$ Y

Order From:

Name: $\quad$ Training Grants Branch, Office of Water Programs

Address: $\quad$ U.S. Environmental Protection Agency

City/State: Washington, DC 20460

Telephone: unknown

Title: WATER, STONES, AND FOSSIL BONES

Publisher: National Science Teachers Association

Copyright: $\mathbf{Y}$

Applicable Area: State: $\mathbf{N}$ Region: $\mathbf{N}$ National: $\mathbf{Y}$

Type of Educational Material:

Curriculum materials:

Demonstrations:

Projects, games:

Other materials: None

Order From:

Name: National Science Teachers Association

Address: 1742 Connecticut Avenue NW

City/State: Washington, DC 20009-1171

Telephone: (202) 328-5800

Activities: $\quad$ Y

Teachers Guide: $\quad$ N

Student Guide: N 


\section{APPENDIX D ACKNOWLEDGMENTS}


This notebook is the first in a series of water-resources professional outreach notebooks. Other notebooks will be developed on the topics of Water Quality, Surface Water, Water Use, and Physical Properties of Water.

This notebook was developed as a cooperative effort between water-resources specialists, practicing teachers, and curriculum development specialists from across the Nation. The following individuals contributed to the development of this notebook:

Stephen J. Vandas - Project Chief of the U.S. Geological Survey's Earth Science Education Program, Denver, Colorado. Steve is a hydrologist, the project manager, and the principal author of this notebook.

Shelly E. Franz - Earth Science Education Specialist, Gainesville, Florida. Shelly was the Region II Environmental Service Project Coordinator with the Florida Department of Education.

Jane N. Crowder - Middle School Science teacher, Bellevue, Washington. Jane co-authored "Earth, the Water Planet," a middle school curriculum resource book published by the National Science Teachers Association (NSTA) and is on the board of directors for NSTA.

Margaret Steinheimer - Middle School Science Teacher, St. Louis, Missouri. Margaret is a Missouri State Presidential Award winner and editor of the Science Plus publication titled "The Communicator."

Rosemary E. Macionus - Manager of Education Programs at the Regional Water Authority, New Haven, Connecticut. Rosemary is the author of the publication "Exploring the Water World" and the designer of the Whitney Water Center, the first water-education facility developed by a water utility in the United States.

Mary Jane V. Schott - Science Unit, State Department of Education, Austin, Texas. Mary Jane is responsible for developing guidelines for curriculum, instruction, and assessment for the State of Texas.

Judith A. Reid - Science Teacher Expert, Anchorage, Alaska. Judy coordinates elementary science curriculum efforts, including teacher training, for the Anchorage School District.

Marsha Barber - High School Science Teacher, Lakewood, Colorado. Marsha is the director of the Denver Earth Science Project.

Virginia Winslow - Middle School Science Teacher, Hingham, Massachusetts. Virginia is the grade 1-4 science specialist at Derby Academy.

Richard A. Herbert - District Chief, U.S. Geological Survey, Water Resources Division, Lawrence, Kansas. Rich was a technical advisor to the project.

Eileen A. Evans - Computer Assistant, U.S. Geological Survey, Water Resources Division, Denver, Colorado. Eileen provided all computer support functions, including data-base development for this notebook. 
The project involved the help and cooperation of a number of other science teachers, water-resources specialists, and curriculum-development specialists from around the Nation. In particular, the following individuals are acknowledged:

Russ Ruswick, High School Science Teacher, Lake Forest, Illinois

Barbara Levi, High School Science Teacher, Chattanooga, Tennessee

Greg Grosser, Middle School Science Teacher, Grafton, Wisconsin

Wilma Baker-Nelson, Middle School Science Teacher, Moscow, Idaho

Jennifer Welborn, Middle School Science Teacher, Northampton, Massachusetts

Elissa Weinroth, Primary School Science Teacher, Montgomery County, Maryland

Karen Matsumoto-Grah, Environmental Educational Specialist, Providence, Utah

Barbara Callison, Science Curriculum Specialist, San Jose State University, California

Shirley Brungardt, Primary and Middle School Science Teacher, Rayville, Missouri

Ken Lull, Hydrologist, U.S. Geological Survey, Water Resources Division, Denver, Colorado

William Hotchkiss, U.S. Geological Survey, Water Resources Division, Denver, Colorado

Marion Fisher, U.S. Army Corps of Engineers, Institute for Water Resources, Ft. Belvoir, Virginia

Darell Nolton, U.S. Army Corps of Engineers, Institute for Water Resources, Ft. Belvoir, Virginia 





included in the WRP Section (p. W-5). Prior to the visit by the WRP, the instructor completes the pre-visit part of the lesson plan. Then the WRP visits the educational event to conduct his or her part of the lesson plan as described in the WRP Section. Additional ground-water educational activities provided in the Appendix can be made available for teaching by the instructor after the WRP visit.

\section{Responsibilities}

The following responsibilities outline a framework to enhance the learning opportunity provided by a WRP when an educational visit is made by the WRP. To implement this framework, direct communications need to take place between the instructor and the WRP. Part of this communication includes the division of certain responsibilities, which are listed below.

\section{Instructor's Responsibilities}

1. Communicate with the WRP concerning your knowledge of water resources. Feel free to ask any questions. This is part of the program.

2. Read the Instructor Section thoroughly.

3. Select lesson plan(s) to be taught by the instructor and the WRP.

4. Complete the Instructor Information Form on page I-4 and promptly return it to the WRP.

5. Complete the pre-visit orientation part of the selected lesson plan with your students.

6. Divide the students into working groups. Appoint a group leader, a group note keeper, and a group supply person. An additional member can be included in a group if there are more than 30 students in a class. The group supply person is responsible for obtaining the materials from the WRP. WRP must be notified and special arrangements made if there are more than 10 groups.

7. Be present during the presentation by the WRP to learn, facilitate, assist, and deal with discipline problems that may arise.

8. Complete the Instructor Evaluation and Student Evaluations after the visit.

\section{Water Resources Professional's Responsibilities}

1. Send a copy of the Instructor Section of the notebook to the instructor immediately after he or she first contacts you. Be sure to fill out your name, address, and phone number at the bottom of the Instructor Information Form located in the Instructor Section on page I-4.

2. After you receive the completed Instructor Information Form back from the instructor, contact the instructor. Ask if she or he has any questions about ground water or the lesson plan(s) to be presented. Discuss the materials needed for the hands-on activity that the instructor and you have agreed upon. (You may need to supply all the materials or just a few.) Discuss the items on the WRP Checklist with the instructor.

3. If requested by the instructor, send a copy of the follow-up activities and selected references to the instructor.

4. Be on time. (Allow a few minutes for setup.) If the presentation is done at a school, check in at the school office to let school officials know who you are, why you are in the building, and the name of the instructor with whom you will be working.

5. Cleanup after the activity.

6. Provide instructor with Instructor Evaluation and Student Evaluation sheets. Complete the WRP Evaluation sheet. 


\section{Lesson Plan Format}

\section{Instructor Section of the Lesson Plan}

Summary/Synopsis - Presents a one-paragraph summary of the lesson plan, designed to assist the instructor in selecting the appropriate lesson plan.

Objectives - States what the students will be doing.

Materials - List of materials required to conduct the hands-on activities presented by the WRP.

Pre-Visit Orientation - Provides students with background information on ground water, allows the instructor to stimulate the students' interests, and leads them to develop ideas and questions concerning the water-resources topic discussed under the Objectives section.

Follow-up - Additional activities for use by the instructor after the WRP's visit.

\section{Water Resources Professional Section of the Lesson Plan}

Summary/Synopsis - Presents a one-paragraph summary of the lesson plan.

Objectives - States what the students will be doing.

Getting Started - Lists the materials and setup requirements necessary for the Ice Breaker and Activity to be presented by the WRP.

Preparation - Preparation required before the educational event.

Ice Breaker - Consists of a demonstration, questions, or dialogue to assist the WRP in developing a rapport with the students.

Activity - Describes the hands-on activity and procedures necessary for completion of the activity for the WRP. The activity will demonstrate an important ground-water property or process. Any data needed for the activity will be supplied for the local area by the WRP.

Application - WRP discusses how the ground-water property or process presented through the activity is applied in the WRP's job. Slides, pictures, reports, data from the area, and other handouts can be used by the WRP to demonstrate the application.

Stewardship - Provides the WRP with environmental stewardship ideas to discuss with the students.

Careers in Water Resources - The WRP discusses his or her career in water resources, including education required, salary, and job duties. Encourage students to ask any questions concerning water and provide them with examples of the application of science to "real-world" situations. 


\section{MATERIALS NEEDED FOR ALL WATER RESOURCES PROFESSIONAL LESSON PLANS}

Following is a list of the materials required to complete all of the WRP lesson plans contained in this notebook. The materials required for individual lesson plans are listed in the "Getting Started" part of each lesson plan. In order to save time it is recommended that a "Master Materials Box" be assembled, containing all the materials required for all the lesson plans. The "Master Materials Box" could be kept next to this notebook. One individual in an office or organization could be responsible for initial collection and for replacement of materials that have been used or discarded.

\section{Materials List for Water Resources Professional Lesson Plan Activities}

Approximately 20 pounds ( 9 kilograms) dry, medium-textured sand

Approximately 20 pounds ( 9 kilograms) dry, pea-size gravel

100 resealable plastic sandwich bags

$10100-\mathrm{mL}$ (3.4-oz) plastic graduated cylinders

1.5-oz bottle blue food coloring

1.5-oz bottle yellow food coloring

100 266-mL (9-oz) clear plastic cups ***

10 grease pencils

10 rulers

One $12^{\prime \prime} \times 6 "$ x 2" (30-cm x 15-cm x 5-cm) plastic ground-water model

10 clear plastic straws or one 10" piece of clear plastic tubing

2-lb. (0.9-kilogram) container plumber's putty or modeling clay

One rock approximately the same size as the piece of sponge listed below but small enough to fit into a 9oz. cup

One sponge approximately the same size as the piece of rock listed above but small enough to fit into a 9oz. cup

10 2-liter (0.53-gallon) clear plastic soft-drink bottles with spout cut off approximately $5 "(12.7 \mathrm{~cm})$ down from the opening, making the plastic container approximately 6 " tall

102 -liter (0.53-gallon) clear plastic soft drink bottle spouts cut off $5^{\prime \prime}$ down from the opening; or 106 "diameter plastic funnels

$2500-\mathrm{mL}$ (16.9-oz) beakers, 2 jars, or water pitchers capable of containing $500 \mathrm{~mL}$ of water

One $2 \mathrm{ft} \times 3 \mathrm{ft}(61-\mathrm{cm} \times 91-\mathrm{cm})$ piece of aluminum-wire window screen

20 plastic pumps or pump dispensers from soft soap or hand lotion containers

One 8" x 11" (20-cm x 27.5-cm) piece of cardboard (back of tablet)

One 5-ft (1.5 meters) piece of small-gauge wire (20 gauge)

One empty bucket for waste 


\section{3 large sponges (for cleanup)}

Slides depicting WRP working on a ground-water project or other water-resources-related project. Slides should show local area and/or include the WRP who is giving the presentation or individuals with whom the WRP works. Slides are provided by WRP and are part of the Careers in Water Resources part of the lesson plans (optional).

Slide projector (optional).

*** A 266-mL (9-oz) clear plastic cup is recommended, although other size cups will work.

\section{NOTES:}

1. Many of the materials can be obtained by the WRP after use of a product. Example: 2-liter soft drink bottles.

2. Information concerning ordering the $12^{\prime \prime} \times 6^{\prime \prime} \times 2^{\prime \prime}$ plastic ground-water models can be found in Appendix A, page A-2.

3. Many sand and gravel outlets will provide a bucket of material free of charge for educational purposes. 


\section{LESSON PLANS}

\section{Topic: Aquifer}

\section{Summary/Synopsis:}

This lesson plan explains how water is stored below land surface in layers of sand, gravel, and rock (geologic formation). It demonstrates the meaning of the terms ground water, porosity, aquifer, and water table. Confined and unconfined aquifers will be discussed. After completing this lesson, students will have a better understanding of underground water storage and the adverse effects of overuse of this valuable natural resource.

Objectives - - The students will:

1. Discuss the uses of ground water in their community.

2. Create an aquifer model and view the saturated and unsaturated zones of the aquifer.

3. Create a lake in the aquifer model and observe the connection between surface water and ground water.

4. Be introduced, through model demonstration, to two different kinds of aquifers, confined and unconfined.

\section{Getting Started:}

Materials - - For demonstration:

1. One $12^{\prime \prime} \times 6^{\prime \prime} \times 2^{\prime \prime}(30-\mathrm{cm} \times 15-\mathrm{cm} \times 5-\mathrm{cm})$ plastic ground water model for demonstration (see Appendix for information on ordering these models).

2. Sufficient pea-size gravel and sand to construct the model. (See diagram on page W-10.)

3. Clear plastic straw or clear plastic tubing.

4. Plumber's putty or modeling clay.

5. Approximately 500-mL (16.9-oz) blue-colored water (use blue food coloring).

6. Approximately 500-mL (16.9-oz) yellow-colored water (use yellow food coloring).

7. Empty container to catch water.

Materials - - For hands-on activity:

1. One 266-mL (9-oz) clear plastic cup for each group.

2. One resealable plastic sandwich bag filled with $3 / 4$ cup of dry, pea-size gravel for each group.

3. One $100-\mathrm{mL}$ (3.4-oz) graduated cylinder for each group.

4. One small bottle of blue food coloring.

5. One grease pencil for each group.

6. 3.8 liters ( 1 gallon) of water.

7. Three large sponges for cleanup.

8. Five slides chosen by the WRP displaying work being done on a ground-water project or other waterresources-related project for Careers in Water Resources portion of lesson plan (optional).

9. Slide projector (optional). 
NOTE: This activity has been developed for small groups of students. Number of groups is limited to 10 or less. If this activity is to be conducted with more than one class in succession, replace the wet materials with dry materials for each group.

\section{Preparation:}

Prior to the educational visit, find out the source (surface or ground water) of the community's water supply and uses of ground water in the community where you will be speaking. If available, find out the depth to ground water, the type of aquifer, aquifer thickness, areal extent of the aquifer, and porosity of the aquifer that makes up the ground-water system beneath the community. For this information, contact the local office of the U.S. Geological Survey.

Set up the 12" x 6" x 2" (30-cm x 15-cm x 5-cm) plastic ground-water model in advance, as shown in the diagram below. Make sure that the confining layer seals tightly around the clear straw or tube, and along the edges of the plastic model.

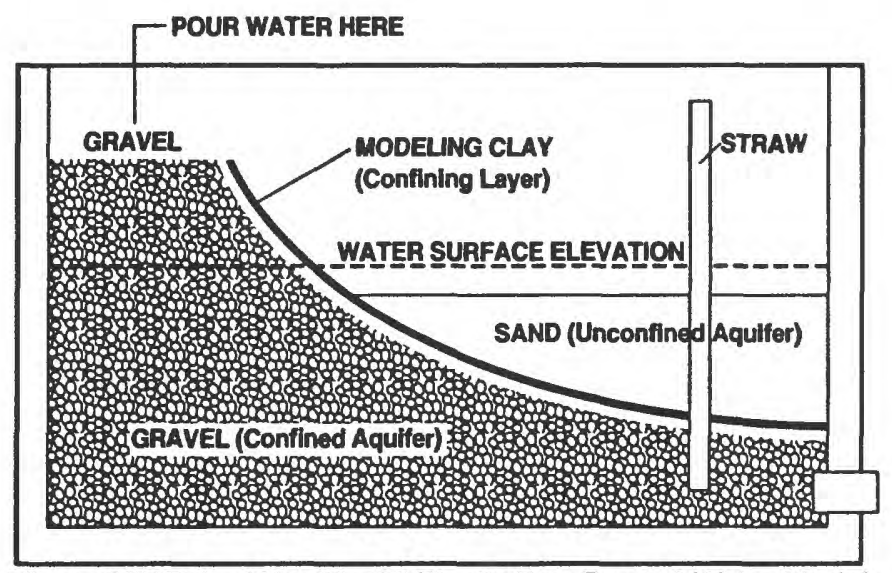

Figure WRP-1. 12" $\times 6^{n} \times 2^{n}$ Plastic Box Ground-Water Model.

To save time, it is recommended that prior to the educational visit you fill resealable plastic sandwich bags (one for each group) with enough pea-size gravel to fill the model cups approximately $3 / 4$ full.

It is also recommended that you try the activity and $12^{\prime \prime} \times 6^{\prime \prime} \times 2^{\prime \prime}$ plastic ground-water model prior to your visit.

\section{Ice Breaker:}

Introduce yourself. Ask the students if they know what a water resources professional is or what a water resources professional does. Identify your place of employment and the job you do within the organization. Inform the students that today's discussion will be about ground water. Ask the students if they know where the water in their community comes from. If their community's water supply is not provided by ground water, tell the students that approximately $42 \%$ of the Nation's population receives its water from ground water. Discuss the origin of their community's water supply. Discuss uses of ground water in the community. Inform the students of the depth to ground water beneath their community. Ask how many of the students have wells at their homes. Have student with well describe the well. 


\section{Activity:}

1. Have the supply person from each group obtain one plastic cup, one resealable plastic sandwich bag containing pea-size gravel, and one graduated cylinder. Have students pour contents of resealable plastic sandwich bag into cup.

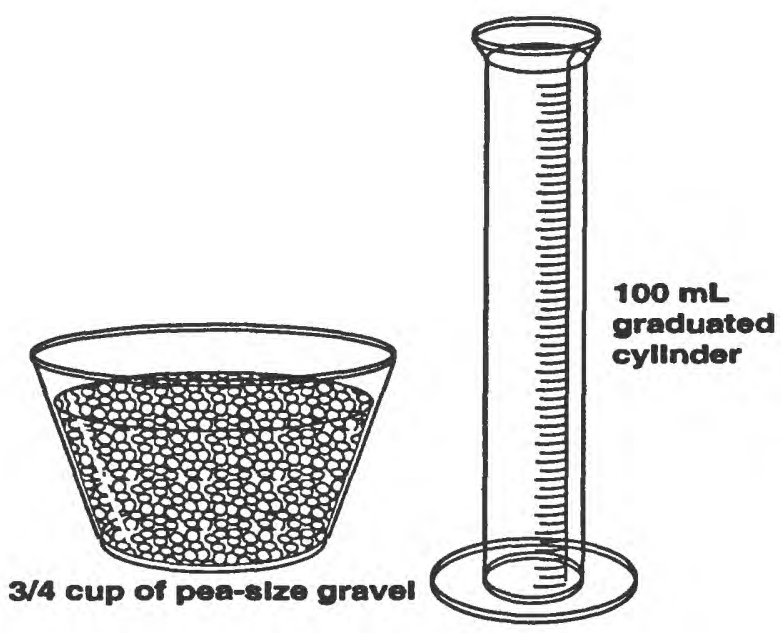

Figure WRP-2. Aquifer Lesson Plan Activity Setup.

2. Ask students what they think will happen if they pour $30 \mathrm{~mL}$ of water into their group's aquifer cup model. Record responses on the chalkboard.

3. Have students pour $30 \mathrm{~mL}$ of water into their group's aquifer cup model and observe what happens. Have students pour an additional $30 \mathrm{~mL}$ of water into their aquifer cup model and observe what happens. Inform the students that they have created an aquifer and discuss the meaning of the word. NOTE: This aquifer is generic and is not intended to represent the local aquifer system.

4. Discuss the concept of saturation. Identify the saturated and unsaturated zones in the aquifer cup model. Help students discover that the aquifer becomes saturated from the bottom of the aquifer cup model upwards.

5. Point out that the top of the saturated zone in their aquifer is the water table.

6. Instruct students to continue to add water until the water table is approximately $1.5 \mathrm{~cm}\left(1 / 2^{\text {") }}\right)$ below the top of the aquifer. Mark water table with the grease pencil on the outside of the cup.

7. Ask students to predict what will happen if they dig a hole in the gravel below the water table. Record responses on the chalkboard.

8. Have students dig a hole in their aquifer cup model and observe the results. Ask students what they have demonstrated. (Answer: a lake or pond.) Have students work together to determine how to make the water table higher or lower. (Add more water or draw water out.)

9. Explain (with the $12^{\prime \prime} \times 6^{\prime \prime} \times 2^{\prime \prime}$ presenter's model) both confined and unconfined aquifers. Add the blue-colored water to the confined aquifer. Add some yellow-colored water to the unconfined aquifer. Use the straw to discuss water surface elevation. The water levels should be different in the two aquifers. Poke a hole in the confining layer, allowing the water in the two aquifers to mix (you will have green-colored water). Discuss the mixing of water between the two aquifers and the new water table. 


\section{Application:}

Discuss the importance of locating and determining the quantity of water available in an aquifer. Explain to the students how WRPs determine water-table elevations and quantity of water stored in an aquifer. Discuss local aquifers and their uses. Inform the students of the type of aquifer that exists beneath their community, its thickness, areal extent, and the kind of geologic materials that form the aquifer.

\section{Stewardship:}

Discuss with the students the uses of ground water in their area. Brainstorm ways ground water might be polluted in the area. Have the students add one drop of blue food coloring to the lake of their model aquifer. Underscore the difficulty of cleaning up pollution by having the students try to flush their models of pollution by adding small amounts of water to their aquifer until the model almost overflows. Have the students pour water from their model aquifer into another container until the water level matches the mark they placed on the cup. Ask the students to look into their model aquifer to see if any colored water is in the aquifer.

\section{Careers in Water Resources:}

See the section titled Careers in Water Resources on page W-34. 


\section{LESSON PLANS}

\section{Topic: Porosity}

\section{Summary/Synopsis:}

Ground water is the source from which we obtain much of the water that we use at home, school, and work. This water is stored in spaces between particles of sand and gravel and in fractures or spaces in rock. The water-holding capacity of earth materials is called porosity. The layer of sand, gravel, or rock that contains water is called an aquifer.

Objectives - - The students will:

1. Discuss the uses of ground water in the community.

2. Create an aquifer model and view how water is stored in the pore spaces of the materials that compose an aquifer.

3. Create two different aquifer models and compare porosities of the materials that compose the different aquifer models.

4. Collect data and keep a data sheet for comparison of different porosities.

\section{Getting Started:}

Materials - - For Ice Breaker:

1. A rock and piece of sponge approximately the same size, but small enough to easily fit into a 266-mL (9-oz) cup.

2. $60-\mathrm{mL}(2.0-\mathrm{oz})$ dry sand.

3. Three 266-mL (9-oz) clear plastic cups capable of holding the objects listed above.

4. Three $100-\mathrm{mL}(3.4-\mathrm{oz})$ graduated cylinders.

5. Sponge for cleanup.

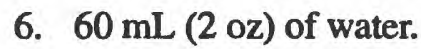

Materials - - For hands-on activity:

1. One 100-mL (3.4-oz) graduated cylinder for each group.

2. Two 266-mL (9-oz) clear plastic cups for each group.

3. One resealable plastic sandwich bag filled with $9 \mathrm{oz}$ of dry pea-size gravel for each group.

4. One resealable plastic sandwich bag filled with $9 \mathrm{oz}$ of a dry sand and pea-size gravel mixture for each group.

5. 3.8 liters ( 1 gallon) of water.

6. One copy of the Porosity Data Sheet for each group (sample on p. W-17).

7. Five slides chosen by the WRP displaying work being done on a ground-water or other waterresources-related project for Careers in Water Resources part of lesson plan (optional).

8. Slide projector (optional).

NOTE: This activity has been developed for small groups of students. Number of groups is limited to 10 or fewer. If this activity is to be conducted with more than one class in succession, replace the wet materials with dry materials for each group. 



\section{Preparation:}

Prior to the educational visit, find out the source (surface or ground water) of the water supply and other uses of ground water in the community where you will be speaking. If available, find out the depth to ground water, the type of aquifer, aquifer thickness, areal extent, and porosity of the ground-water system beneath the community. For this information, contact the local office of the U.S. Geological Survey.

To save time, it is recommended that you fill one resealable plastic sandwich bag (one for each group) with enough dry, pea-size gravel to completely fill the model cup and one resealable plastic sandwich bag with enough dry sand and pea-size gravel mix to completely fill the model cup. Make 11 copies of the Porosity Data Sheet on page W-17 of this activity. It is also recommended that you try this activity prior to your educational visit.

\section{Ice Breaker:}

Introduce yourself. Ask the students if they know what a water resources professional is or what a water resources professional does. Identify your place of employment and the job you do within the organization. Inform the students that today's discussion will be about ground water. Ask the students if they know the source of their water supply. Discuss the origin of their water supply. If their community's water supply is not provided by ground water, tell the students that approximately 42 percent of the Nation's population receives their water from ground water. Inform the students of the depth to ground water beneath where the educational event is taking place (if applicable). Ask how many of the students have wells at home. Can they tell anything about the well; depth, well yields, water quality?

Begin the demonstration by placing the rock, piece of sponge, and the $60 \mathrm{~mL}(2.0 \mathrm{oz})$ of dry sand in three separate $266-\mathrm{mL}(9-\mathrm{oz})$ clear plastic cups. Put $20 \mathrm{~mL}(0.7 \mathrm{oz})$ of water in each of the three $100-\mathrm{mL}$ (3.4-oz) graduated cylinders.
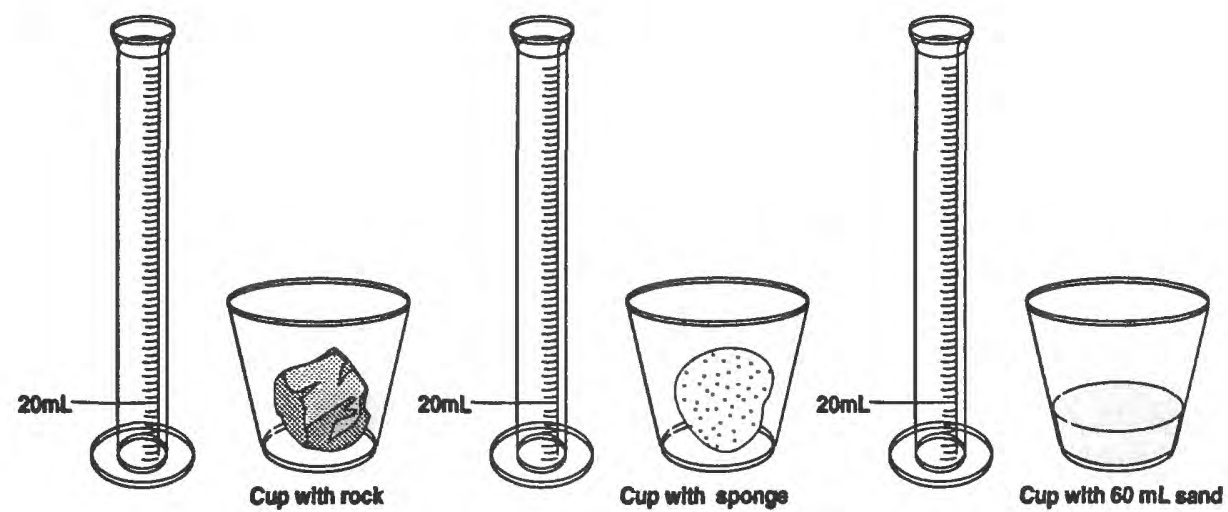

Figure WRP-3. Ice Breaker Demonstration Setup.

Ask the students what will happen if you pour the contents of the graduated cylinders $(20 \mathrm{~mL})$ into each of the cups. Beginning with the cup that contains the rock, pour equal amounts of water $(20 \mathrm{~mL})$ into each of the three cups. Then pour the free-standing water back into the graduated cylinders and record on the chalkboard the amount of returned water for each cup. How much water remains in each cup? Does each material hold equal quantities of water? (Answer: No.) Why? (Answer: Because each material holds a different volume of water in its pore spaces.) Which material holds the most water?

Introduce the term porosity. 


\section{Activity:}

1. Have the supply person from each group obtain two 266-mL (9-oz) cups, one resealable plastic sandwich bag filled with dry, pea-size gravel, one resealable plastic sandwich bag filled with dry sand and pea-size gravel mixture, a graduated cylinder, and a copy of the Porosity Data Sheet.

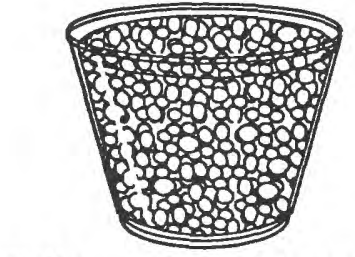

Full cup of pea-size gravel

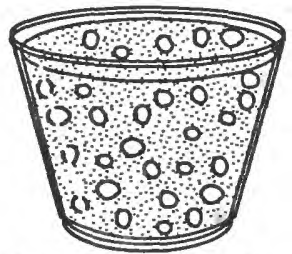

Full cup of pea-size gravel and sand mixture

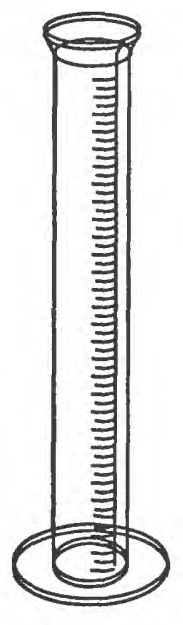

Figure WRP-4. Porosity Lesson Plan Activity Setup.

Have students pour contents of resealable plastic sandwich bags into separate cups. Ask students to predict what will happen when they pour water into each cup. (Answer: The cups will hold water.) Then, ask the students which cup, the one with pea-size gravel or the one with the sand and peasize gravel mix, will hold the most water. (Answer: The cup containing only pea-size gravel because it contains larger voids or spaces between the pieces of well-sorted gravel. In the sand and pea-size gravel mix, the sand particles fill in some pores between the gravel. This results in a lower percent porosity.) Have the students guess the amount of water in milliliters that each will contain. Have a member of each group record the group's data on the Porosity Data Sheet. Keep an allinclusive prediction chart on the chalkboard.

NOTE: Porosities of unconsolidated deposits depend on the range in grain sizes (sorting) and on the shape of the rock particles. Well-sorted materials tend to have the largest porosities due to a lack of smaller particles to fill in voids and pore spaces. Poorly sorted materials, due to a wider range in particle sizes, have less available space between particles for storing water. Thus, porosity depends not on the absolute size (large or small) of the aquifer material, but more on the degree of sorting (range of particle sizes). Porosity can also be affected by the angularity of the material (especially in unconsolidated particles) and the crystalline structure of the minerals that compose a rock formation (e.g., clay beds) of consolidated materials. 
2. Have each group pour water from a filled $100-\mathrm{mL}$ (3.4-oz) graduated cylinder slowly into each cup until the water just reaches the top of the materials in the cup. Caution students to be careful when pouring the water into cups since water may splash as it hits the material in the cup. Calculate the amount of water poured into each cup (volume of water in filled graduated cylinder minus the volume of water remaining in cylinder). Students will have to refill the graduated cylinder with water for the second cup. Calculate the percent porosity of the materials. A 9-oz cup contains approximately $266 \mathrm{~mL}$.

$$
\% \text { porosity }=\frac{\text { volume of water poured in cup }(\mathrm{mL})}{\text { total volume of cup }(266 \mathrm{~mL})} \times 100
$$

Have the record keeper from each group record data on the Porosity Data Sheet. Obtain data from each group and record on the chalkboard.

3. From data, draw conclusions concerning the porosity of each cup of material. Ask why there are different porosities between the materials in the cups. (Answer: Sorting.) Explain that the ability of the material to hold water is termed porosity. Discuss the different porosities of the materials.

4. Have each group pour water from the cup back into the graduated cylinder to see if all the water will leave the materials in the cup. Have students discuss the fact that some water does not return to the graduated cylinder because it adheres to the materials in the cup. Discuss the implications of this observation (i.e., not all of the water is available from an aquifer.)

\section{Application:}

Discuss the importance of locating and determining the quantity of water available in an aquifer. Discuss with the students how WRPs determine porosities and the quantity of water stored in an aquifer.

Porosity can be determined in the laboratory by taking a sample of aquifer material of known volume. The sample is dried at $105^{\circ} \mathrm{C}$ until it reaches a constant weight. The dried sample is submerged in a known volume of water and placed in a sealed container until it is saturated so there will be no evaporation loss. The porosity is the volume of voids (equal to the original water volume minus the volume of water left in the container after saturation) divided by the volume of the saturated sample, i.e., the ratio of the volume of void spaces to the total volume of the saturated sample. See porosity diagram on page W-35.

Discuss local aquifers and their uses. If the information is available, discuss with the students the depth to ground water in their community, the aquifer types, the aquifer thickness, areal extent of the local aquifer, and the porosity of the local aquifer.

Read the percent porosity from the table of Representative Porosity Ranges for Sedimentary Materials included with this lesson plan. Discuss these quantities. Compare the percent porosities computed by the students to the gravel, and sand and gravel porosity ranges displayed on the table.

\section{Stewardship:}

Discuss the uses of ground water in the area with the students. Brainstorm ways to conserve ground water based upon the area's ground-water uses.

\section{Careers in Water Resources:}

See the section titled Careers in Water Resources on page W-34. 


\section{Porosity Data Sheet}

\section{Date}

Material

Volume of water poured into cups, in

\% Porosity $\underline{\mathrm{mL}}$

Sand and gravel mixture

Sand and gravel mixture

$$
\begin{aligned}
& \% \text { porosity }=\frac{\text { measured water, in } \mathrm{mL}}{\text { measured volume of cup, in } \mathrm{mL}} \times 100 \\
& 1 \mathrm{oz}=30 \mathrm{~mL}
\end{aligned}
$$




\section{Representative Porosity Ranges for Sedimentary Materials}

\author{
Material
}

Soils

Uniform sand

Fine to medium mixed sand

Gravel

Gravel and sand

Sandstone

Shale

Limestone

\author{
Porosity \%
}

$30-40$

$30-35$

$30-40$

20-35

$10-20$

$1-10$

1-10

Source: Handbook of Applied Hydrology: Chow, 1964, McGraw-Hill. 


\section{LESSON PLANS}

\section{Topic: Permeability}

\section{Summary/Synopsis:}

Ground water is stored in the spaces or pores between sand grains and individual pieces of gravel, or in pores and/or fractures in rocks below the land surface. Water must be able to flow through these pore spaces to be available for use. The ability of rock materials to transmit water is termed permeability. Different materials have different permeabilities. The greater the permeability of an aquifer, the greater the volume of water that can be obtained from the aquifer over a given period of time.

Objectives - - The students will:

1. Discuss the uses of ground water in their community.

2. Measure the rate of water flow through different materials (sand vs. gravel).

3. Collect data and keep a data sheet for comparison of the different permeabilities of sand and gravel.

4. Learn that different materials have different permeabilities.

\section{Getting Started:}

Materials - - For Ice Breaker:

1. A rock and piece of sponge approximately the same size, but small enough to easily fit into a 266-mL (9-oz) cup.

2. 60-mL (2-oz) dry sand.

3. Three 266-mL (9-oz) clear plastic cups capable of holding the objects listed above.

4. Three $100-\mathrm{mL}$ (3.4-oz) graduated cylinders.

5. Sponge for cleanup.

6. $60 \mathrm{~mL}(2 \mathrm{oz})$ of water.

\section{Materials - - For hands-on activity:}

1. One cut-off spout from 2-liter soft drink container or one 15-cm (6") funnel for each group.

2. One clear container for each group, deep enough to support the funnels and allow $100 \mathrm{~mL}$ (3.4 oz) of water to be captured without restricting the flow of water out of the funnels. The bottom part of the 2-liter soft drink container is recommended.

3. One resealable plastic sandwich bag containing enough dry, pea-size gravel to fill the soft drink container spout or funnel approximately $1 / 3$ full for each group.

4. One resealable plastic sandwich bag containing enough dry sand to fill the soft drink container spout or funnel approximately $1 / 3$ full for each group.

5. One 100-mL (3.4-oz) graduated cylinder for each group.

6. Two small pieces of aluminum window screen, approximately 3 " in diameter for each group.

7. Clock or watch with second hand.

8. One copy of the Permeability Data Sheet for each group. 
9. Five liters (1.3 gallons) of water.

10. Five slides chosen by the WRP displaying work being done on a ground-water project or other waterresources-related project for Careers in Water Resources part of lesson plan (optional).

11. Slide projector (optional).

NOTE: This activity can be done as a demonstration. If done as a demonstration, set up two models so that the experiment can be done at the same time. Solicit student volunteers to pour the water into the funnels and to keep time. Repeat the experiment three times, using dry materials and different student assistants for each repetition. Average and discuss the results of the three repetitions.

\section{Preparation:}

Prior to the educational visit, find out the source (surface or ground water) of the water supply and other uses of ground water in the community where you will be speaking. Also, find out the depth to ground water, the type of aquifer, aquifer thickness, areal extent, and porosity of the ground-water system beneath the community. For this information, contact the local office of the U.S. Geological Survey.

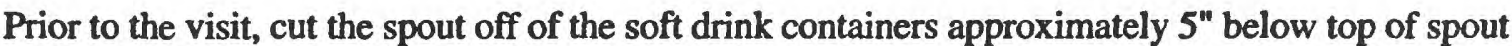
(Figure WRP-5). Insert the spout in the bottom part of the 2-liter soft drink container as shown in

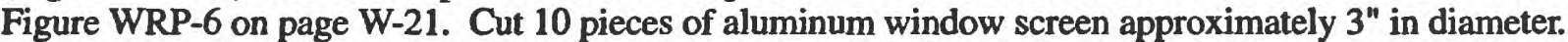
Make 11 copies of the Permeability Data Sheet on page W-24.

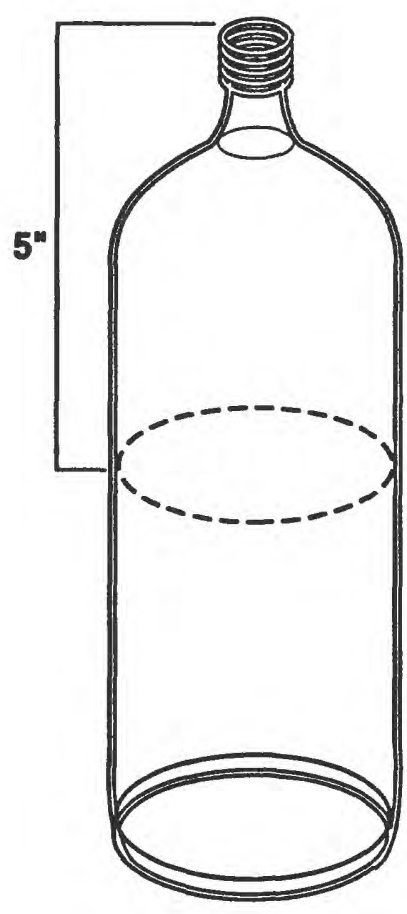

Flgure WRP-5. Creating a Spout and Container from a 2-L Soft Drink Container. 
To save time, it is recommended that you fill 10 resealable plastic sandwich bags (one for each group) with enough dry, pea-size gravel to fill the soft drink container spout approximately $1 / 3$ full and 10 resealable plastic sandwich bags (one for each group) with an equal amount of dry sand. It is also recommended that you try this activity prior to your educational visit.

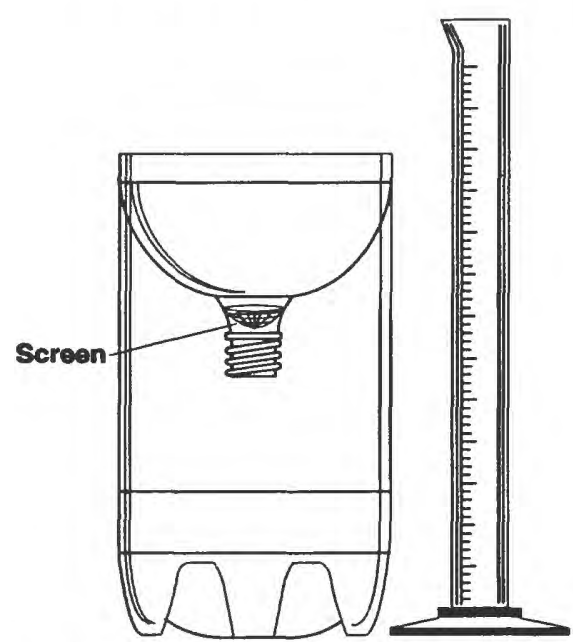

Figure WRP-6. Permeability Lesson Plan Activity Setup.

\section{Ice Breaker:}

Introduce yourself. Ask the students if they know what a water resources professional is or what a water resources professional does. Identify your place of employment and the job you do within the organization. Inform the students that today's discussion will be about ground water. Ask the students if they know the source of their water supply. Discuss the origin of their water supply. If their community's water supply is not provided by ground water, tell the students that approximately $42 \%$ of the Nation's population receives their water from ground water. Inform the students of the depth to ground water underneath where the educational event is taking place (if applicable). Ask how many of the students have wells at home. Can they tell anything about the well; depth, etc.

Begin the demonstration by placing the rock, piece of sponge, and the $60 \mathrm{~mL}(2.0 \mathrm{oz})$ of dry sand in three separate $266-\mathrm{mL}$ (9-oz) clear plastic cups. Put $20 \mathrm{~mL}(0.7 \mathrm{oz})$ of water in each of the three $100-\mathrm{mL}$ (3.4-oz) graduated cylinders.
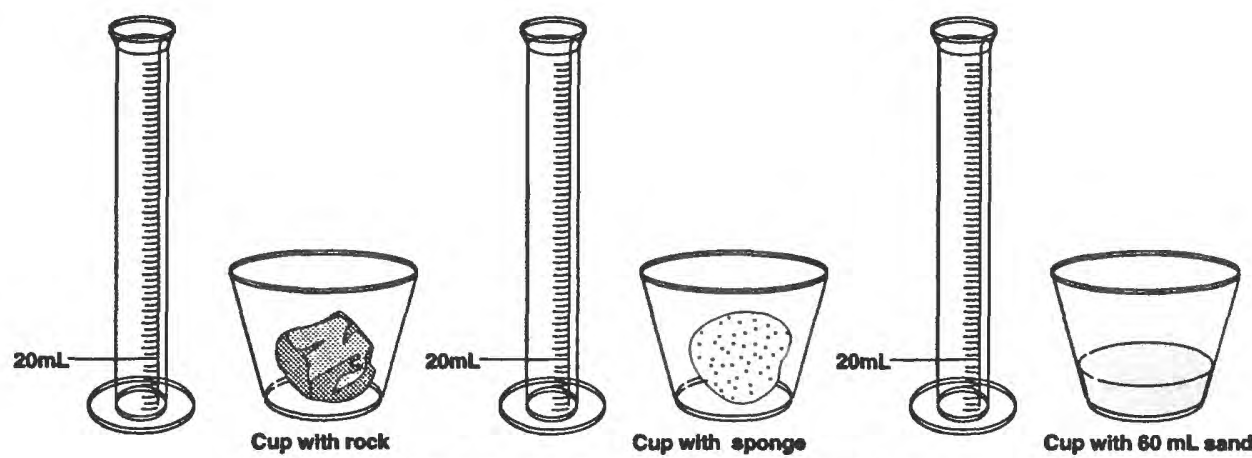

Figure WRP-7. Ice Breaker Demonstration Setup. 
Ask the students what will happen if you pour the contents of the graduated cylinders $(20 \mathrm{~mL})$ into each of the cups. Beginning with the cup that contains the rock, pour equal amounts of water $(20 \mathrm{~mL})$ into each of the three cups. Then pour the free-standing water back into the graduated cylinders and record on the chalkboard the amount of returned water for each cup. How much water remains in each cup? Does each material hold equal quantities of water? (Answer: No.) Why? (Answer: Because each material holds a different volume of water in the voids or pores.) Which material holds the most water?

Introduce the term porosity.

\section{Activity:}

1. Have the supply person from each group obtain one 2-liter soft drink container spout or funnel, one 2-liter soft drink container bottom, one resealable plastic sandwich bag of dry sand, one resealable plastic sandwich bag of dry gravel, one screen, and a $100-\mathrm{mL}$ graduated cylinder.

2. Have the students place the screens in the bottom of the soft drink bottle spouts or funnels to prevent sand or gravel from running out the bottom or going through the spout.

3. Place the soft drink bottle spout or funnel in the top of the container as shown in Figure WRP-6 on page W-21.

4. Pour the sand from the resealable plastic sandwich bag into the soft drink bottle spout or funnel.

5. Pour $100 \mathrm{~mL}$ ( $3.4 \mathrm{oz}$ ) of water into the soft drink bottle spout or funnel and time how long it takes for the water to drain into the bottom of the container. Stop timing when the stream slows to 2 drips per second.

6. Have the group's note keeper record on the Permeability Data Sheet the time it takes for the water to go through the materials.

7. Invert the container and pour the liquid back into the graduated cylinder or the measuring cup. Record the quantity of water remaining in the sand.

8. Repeat steps 5-7 with the wet sand. Record these results on the Permeability Data Sheet.

9. Remove the sand from the 2-liter soft drink container spout. Repeat steps $2-8$ with the dry pea-size gravel contained in the resealable sandwich bag.

10. Repeat steps 5-7 with the wet pea-size gravel. Record these results on the Permeability Data Sheet.

After completion of the activity, record the results from each group on the chalkboard. Which material had the greatest permeability? (Answer: Gravel) Why? (Answer: Pore spaces were larger and better connected.) Why were there different quantities of water remaining after each experiment? (Answer: More water remained in the smaller pore spaces of the sand.) Discuss the relationship between the amount of water remaining and the permeability of the materials. What happened when the experiment was repeated with the wet materials?

\section{Application:}

Discuss the importance of locating and determining the quantity of water available in an aquifer and assessing the ability of that aquifer to supply water to springs, wells, ponds, etc.

Discuss with the students how WRPs determine permeability. Discuss local aquifers and their uses.

Permeability can be determined in the lab or in the field. Determination of permeability in the field involves the use of wells. Observation wells-wells a known distance from the well to be pumped-are used. A known volume of water is removed or added to the pumped well over a known period of time. The lowering or raising of the water table in unconfined aquifers is measured in the observation wells. This information is plotted on a graph and compared to a standard graph to arrive at an estimate of permeability. 
Discuss local aquifers and their uses. Discuss with the student the depth to ground water in their community, the aquifer types, the aquifer thickness, areal extent of the local aquifer, and the porosity of the local aquifer.

Stewardship:

Brainstorm with the students sources of pollution in the area. Discuss how fast these materials could move through different aquifer materials.

\section{Careers in Water Resources:}

See the section titled Careers in Water Resources on page W-34. 


\section{Water Resources Professional's Outreach Notebook Ground Water Grade Level 6-8}

U.S. Geological Survey

Open-File Report 94-73 


\section{Permeability Data Sheet}

Date

\begin{tabular}{|c|c|c|c|}
\hline $\begin{array}{l}\text { Dry } \\
\text { Material }\end{array}$ & $\begin{array}{l}\text { Time in } \\
\text { Seconds }\end{array}$ & $\begin{array}{l}\text { Quantity of Water } \\
\text { Water that Flowed } \\
\text { Through Material }\end{array}$ & $\begin{array}{c}\text { Water Remaining in } \\
\text { Material }\end{array}$ \\
\hline
\end{tabular}

Sand

Gravel

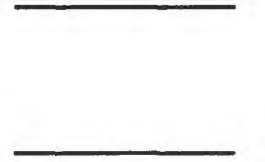

$\longrightarrow$

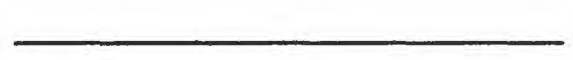
Quantity of Water
Wet Time in
Material Seconds Water that Flowed Through Material Water Remaining in
Material

Sand

Gravel

Water remaining in sand or gravel $=100 \mathrm{~mL}(3.4 \mathrm{oz})$ minus the quantity of water that flowed through materials, in $\mathrm{mL}$. 


\section{LESSON PLANS}

\section{Topic: Wells}

\section{Summary/Synopsis:}

Wells are pits, holes, or shafts sunk or driven into the Earth to tap an underground supply of water. People use this water in their homes, schools, businesses, and for agricultural purposes. Ground water is an essential natural resource that needs to be protected. We need to understand how water is removed from aquifers and the results of removing too much water from an aquifer.

Objectives - - The students will:

1. Discuss the uses of ground water in their communities.

2. Create an aquifer model and place a well in the model.

3. Measure and record the depth to water in a well from the simulated land surface.

\section{Getting Started:}

Materials -- For Ice Breaker:

1. A rock and piece of sponge approximately the same size, but small enough to easily fit into a 266-mL (9-oz) cup.

2. 60-mL (2-oz) dry sand.

3. Three 266-mL (9-oz) clear plastic cups capable of holding the objects listed above.

4. Three 100-mL (3.4-oz) graduated cylinders.

5. Sponge for cleanup.

6. $60 \mathrm{~mL}(2 \mathrm{oz})$ of water.

Materials - - For hands-on activity:

1. Two clear plastic $266-\mathrm{mL}$ (9-oz) cups for each group.

2. One piece of fine wire window screen for each group, approximately $3^{\prime \prime} \times 3$ ". This wire screen will be rolled around a pencil several times to make a cylinder.

3. One 7.6-cm (3") length of wire for each group.

4. One plastic pump for each group.

5. One 100-mL (3.4-oz) graduated cylinder for each group.

6. Three cardboard strips $1 / 4$ " wide by 5 "long. These cardboard strips must be able to fit into the rolled wire screen. Cut cardboard strips from the cardboard located on the back of a notebook pad.

7. One resealable plastic bag filled with enough dry, pea-size gravel to fill the model cup approximately $3 / 4$ full for each group.

8. One ruler with metric units for each group. 
9. Copy of Well Data Sheet for each group.

10. 3.8 liters ( 1 gallon) of water.

11. Food coloring (for pollution demonstration).

12. Five slides chosen by the WRP displaying work being done on a ground-water project or other waterresources-related project for Careers in Water Resources part of lesson plan (optional).

13. Slide projector (optional).

NOTE: It is not recommended that this activity be done as a demonstration. Be sure there are sufficient materials for each group.

\section{Preparation:}

Prior to the educational visit, find out the source (surface or ground water) of the water supply and other uses of ground water in the community where you will be speaking. If available, find out the depth to ground water, the type of aquifer, aquifer thickness, areal extent, and porosity of the ground-water system beneath the community. This information can be obtained by calling the local office of the U.S. Geological Survey.

To save time, it is recommended that you prepare for each group one wire screen cylinder by rolling the wire screen around a pencil and securing the screen cylinder with a small piece of wire. Retain the cylinders after the presentation for future use. For each group, fill one resealable plastic sandwich bag with enough pea-size gravel to fill the model cup approximately $3 / 4$ full. Also, prepare thirty $1 / 4$ " $\times 5$ " cardboard strips using the cardboard from the back of a notebook pad. Make eleven copies of the Well Data Sheet found on p. W-29. It is recommended that you try this activity prior to your educational visit.

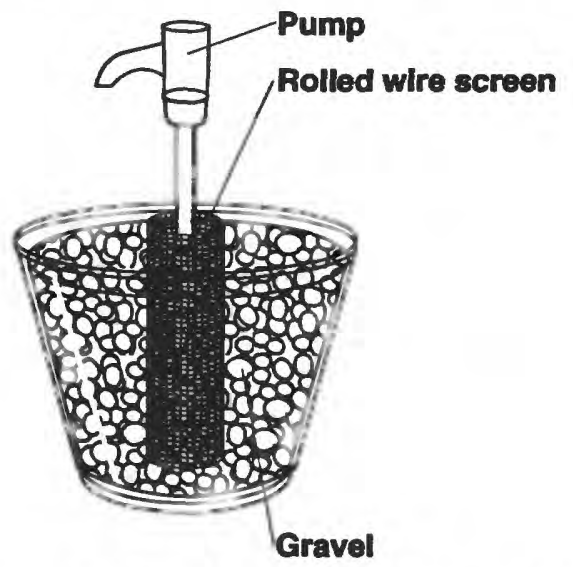

Ice Breaker:

Figure WRP-8. Wells Lesson Plan Activity Setup.

Introduce yourself. Ask the students if they know what a water resources professional is or what a water resources professional does. Identify your place of employment and the job you do within the organization. Inform the students that today's discussion will be about ground water. Ask the students if they know the source of their water supply. Discuss the origin of their water supply. If their community's water supply is not provided by ground water, tell the students that approximately $42 \%$ of the Nation's population does receive water from the ground. Inform the students of the depth to ground water beneath where the educational event is taking place (if applicable). Ask how many of the students have wells at home. Can they tell anything about the well; depth, etc.? 
Begin the demonstration by placing the rock, piece of sponge, and the $60 \mathrm{~mL}$ ( $2.0 \mathrm{oz}$ ) of dry sand in three separate 266-mL (9-oz) clear plastic cups. Put $20 \mathrm{~mL}(0.7 \mathrm{oz})$ of water in each of the three $100-\mathrm{mL}$ (3.4-oz) graduated cylinders.
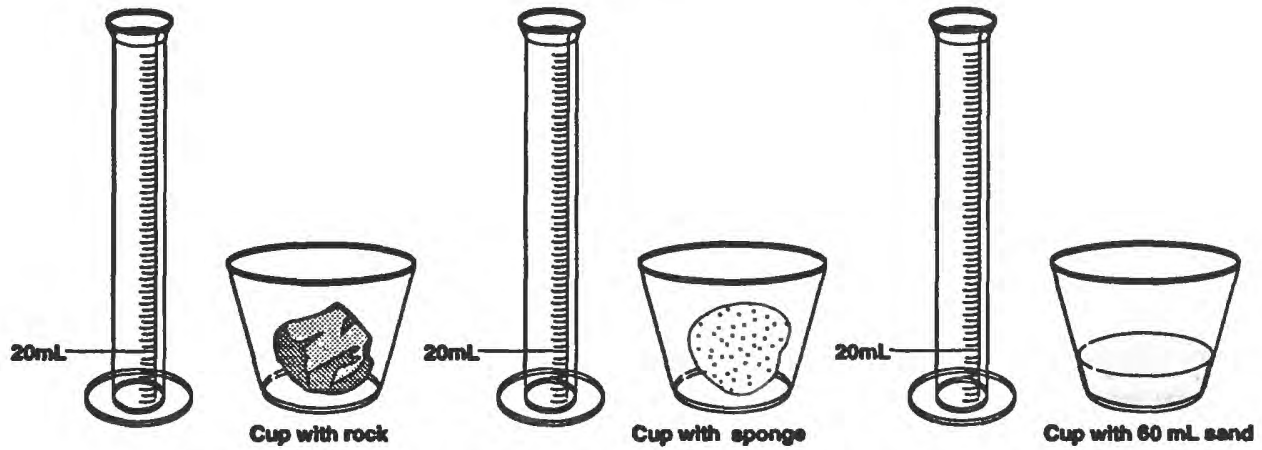

Figure WRP-9. Ice Breaker Demonstration Setup.

Ask the students what will happen if you pour the contents of the graduated cylinders $(20 \mathrm{~mL})$ into each of the cups. Beginning with the cup that contains the rock, pour equal amounts of water $(20 \mathrm{~mL})$ into each of the three cups. Then pour the free-standing water back into the graduated cylinders and record on the chalkboard the amount of returned water for each cup. How much water remains in each cup? Does each material hold equal quantities of water? (Answer: No.) Why? (Answer: Because each material holds a different volume of water in the pore spaces.) Which material holds the most water?

Introduce the term porosity.

\section{Activity:}

1. Have the supply person from each group obtain two clear plastic cups, one wire-screen cylinder, one plastic pump, one graduated cylinder, three cardboard strips, a copy of the Well Data Sheet, and one resealable plastic bag with pea-size gravel.

2. Instruct students to place the screen cylinder to one side of the plastic cup so that it rests on the bottom of the cup. (The screen cylinder represents a well.) Fill the cup $3 / 4$ full with the pea-size gravel from the resealable plastic sandwich bag, keeping the gravel out of the cylinder.

3. Have students predict what will happen to the water level in the well (screen cylinder) when they pour water onto the pea-size gravel. Instruct the students to pour water onto the pea-size gravel, filling the cup model approximately half way.

4. Instruct the students to insert one of the cardboard strips all the way into the well until it hits bottom. Have the students place a mark on the cardboard strip even with the top of the well. Determine the depth of the well by measuring from the mark the students made to the bottom of the cardboard strip. Record this data on the Well Data Sheet.

5. Using the same cardboard strip, have the students measure the distance from the mark they put on the cardboard strip to the top of the wet portion of the cardboard strip. This distance is the depth to water from the top of the well. Record this data on the Well Data Sheet.

6. Have students compare the depth of the water inside the well with the height of the water in the cup model.

7. Using this model of a well, explain the concepts of the water table and aquifer.

8. Have students identify the water table and the aquifer in their cup model. 
9. Have students predict what will happen to the water level in the well if some of the water is pumped out of the well. Ask students to use the plastic pump to remove water from the well. Using a different cardboard strip, have students measure and record on the data sheet the depth of well and depth to water below the top of the well as described in 4 and 5 above.

10. Have students predict what will happen to the water level in the well if additional water is added (recharge). Test their prediction by adding $10 \mathrm{~mL}$ of water. Using the third cardboard strip, have students measure and record on the data sheet the depth of the well and depth to water below land surface as described in 4 and 5 above.

11. Have students discuss what would happen if recharge and pumping were to happen at the same time.

12. Ask for a volunteer to explain in his or her own words how a well works. Explain the relationship between a well, water table, porosity, permeability, and an aquifer.

Possible Answers:

Well - a large opening which has been dug, drilled, or bored in an aquifer from which water can be pumped.

Water table - the top of the saturated zone or water in the aquifer.

Porosity - the spaces in a material divided by the total volume.

Permeability - the ability of water to move through porous or fractured materials.

Aquifer - underground material that contains and transmits water.

\section{Application:}

If available, show slides of a well being drilled. Discuss the importance of locating and determining the quantity and quality of water available in an aquifer. Discuss how WRPs determine water-table elevations, aquifer porosities, and the quantity of water stored in an aquifer.

Discuss local aquifers and their uses. If available, discuss the depth to ground water in the community, the type of aquifer that exists, the aquifer thickness, areal extent, and its porosity.

\section{Stewardship:}

Discuss with the students the uses of ground water in their community. Brainstorm ways ground water might be polluted in their community. Have the students add one drop of food coloring to their aquifer cup model. Underscore the difficulty of cleaning up pollution by having the students attempt to "flush" pollution from their models by adding and then pumping water out of the model.

\section{Careers in Water Resources:}

See the section titled Careers in Water Resources on page W-34. 


\section{Well Data Sheet}

\section{MEASUREMENTS:}

Depth of Well

(cm)
Depth to Water from Top of Well

(cm)

\section{Initial setup \\ Cup half full of water}

2. Add $10 \mathrm{~mL}$ water

3. Pump well 


\section{LESSON PLANS}

\section{Topic: Calculations}

\section{Summary/Synopsis:}

Ground water is an essential source of water that people use at home, school, and work. The amount of ground water that is stored in layers of sand, gravel, and rock can be determined mathematically. Using a simple aquifer model constructed by the students, the volume of spaces between particles of pea-size gravel can be measured. By understanding these concepts, it is possible to determine the quantity of water in storage in a model aquifer. Similar measurements are made by WRPs to determine the quantity of ground water in an aquifer.

Objectives - - The students will:

1. Practice their mathematical skills:

a. Measure the length, width, and height of an aquifer model.

b. Calculate the volume of the aquifer model from these measurements.

c. Calculate the volume of water that the model aquifer can hold.

2. Students will study the following aspects of ground-water systems and quantify their observations:

a. Saturated-zone dimensions;

b. Depth to water table;

c. Aquifer dimensions;

d. Porosity.

\section{Getting Started}

Materials - - For Ice Breaker:

1. A rock and piece of sponge approximately the same size, but small enough to easily fit into a $266-\mathrm{mL}$ (9-oz) cup.

2. $60-\mathrm{mL}(2-0 \mathrm{z})$ dry sand.

3. Three 266-mL (9-oz) clear plastic cups capable of holding the objects listed above.

4. Three 100-mL (3.4-oz) graduated cylinders.

5. Sponge for cleanup.

6. $60-\mathrm{mL}(2-\mathrm{oz})$ of water.

Materials - - For hands-on activity:

1. One 2-liter soft drink container with spout cut off approximately $12.7 \mathrm{~cm}\left(5^{\prime \prime}\right)$ below the spout or a clear square baking pan approximately $12.7 \mathrm{~cm}\left(5^{\prime \prime}\right)$ deep for each group.

2. Sufficient dry, pea-size gravel to fill all the containers $3 / 4$ full. This will be approximately $20 \mathrm{lbs}$.

3. One 100 - $\mathrm{mL}$ graduated cylinder for each group.

4. One ruler with metric units for each group.

5. Pencils and paper.

6. 7.6 liters ( 2 gallons) of water. 


\section{Sponges for cleanup.}

8. Five slides chosen by the WRP displaying work being done on a ground-water project or other waterresources-related project for Careers in Water Resources part of lesson plan (optional).

9. Slide projector (optional)

NOTE: This activity can be done as a demonstration or a group activity. If done as a group activity, be sure there are sufficient materials for each group in the class.

\section{Preparation:}

Prior to the educational visit, find out the source (surface or ground water) of the community's water supply and uses of ground water in the community where you will be speaking. If available, find out the depth to ground water, the type of aquifer, aquifer thickness, areal extent, and porosity of the ground-water system beneath the community. This information can be obtained by calling the local office of the U.S. Geological Survey.

If you choose to use the base of a 2-L soft drink container, cut the spout off the container approximately $5^{\prime \prime}$ below top of spout.

See Figure WRP-10 for Calculations Lesson Plan Activity Setup.
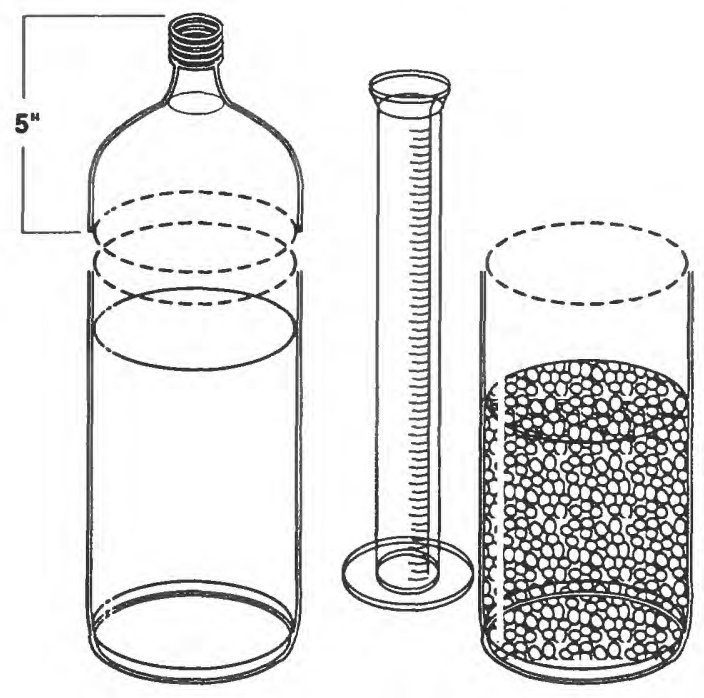

Figure WRP-10. Calculations Lesson Plan Activity Setup.

$$
\begin{aligned}
& \text { Bottom of } 2-L \text { bottle } \\
& \text { with top } 5^{\prime \prime} \text { cut off, filled } \\
& 3 / 4 \text { full of pea-size gravel }
\end{aligned}
$$

\section{Ice Breaker:}

Introduce yourself. Ask the students if they know what a water resources professional is or what a water resources professional does. Identify your place of employment and the job you do within the organization. Inform the students that today's discussion will be about ground water. Ask the students if they know the source of their water supply. Discuss the origin of their water supply. If their community's water supply is not provided by ground water, tell the students that approximately $42 \%$ of the Nation's population does receive water from ground water. Inform the students of the depth to ground water beneath where the educational event is taking place (if applicable). Ask how many of the students have wells at home. Can they tell anything about the well; depth, etc.? 
Begin the demonstration by placing the rock, piece of sponge, and the $60 \mathrm{~mL} \mathrm{(2} \mathrm{oz)} \mathrm{of} \mathrm{dry} \mathrm{sand} \mathrm{in}$ three separate $266-\mathrm{mL}$ (9-oz) clear plastic cups. Put with $20 \mathrm{~mL}(0.7 \mathrm{oz})$ of water in each of the three 100$\mathrm{mL}$ (3.4-oz) graduated cylinders.

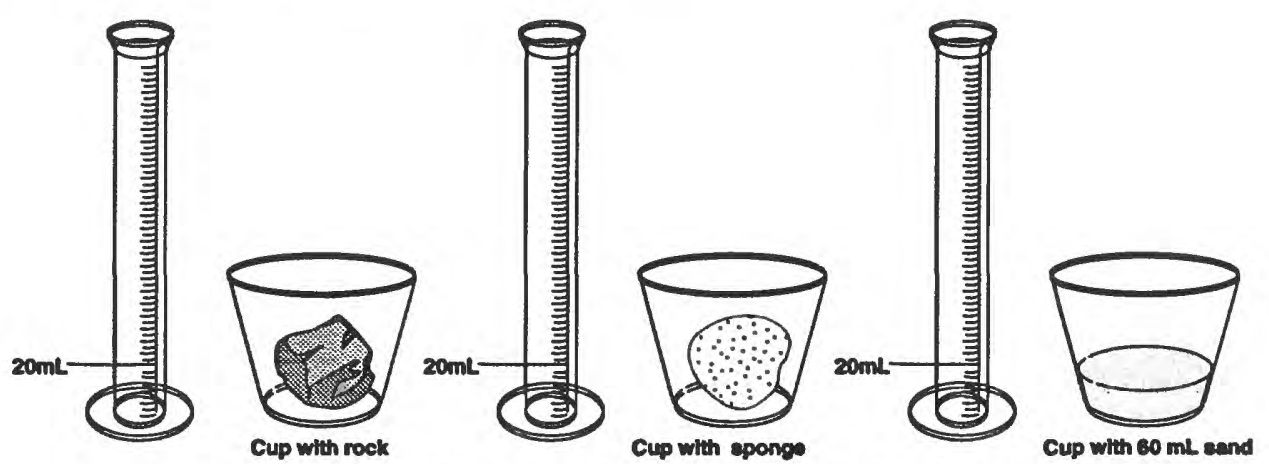

Figure WRP-11. Ice Breaker Demonstration Setup.

Ask the students what will happen if you pour the contents of the graduated cylinders $(20 \mathrm{~mL})$ into each of the cups. Beginning with the cup that contains the rock, pour equal amounts of water $(20 \mathrm{~mL})$ into each of the three cups. Then pour the free-standing water back into the graduated cylinders and record on the chalkboard the amount of returned water for each cup. How much water remains in each cup? Does each material hold equal quantities of water? (Answer: No.) Why? (Answer: Because each material holds a different volume of water in the pore spaces.) Which material holds the most water?

Introduce the term porosity.

\section{Activity:}

1. Have the supply person from each group obtain one model container, fill it $3 / 4$ full of pea-size gravel, a $100-\mathrm{mL}$ graduated cylinder, and a ruler.

2. Use the graduated cylinder to measure the quantity of water, then pour into the container. Continue adding measured quantities of water to the gravel until only the top $2.5-\mathrm{cm}(1$ ") is not saturated with water.

3. Explain to students that they have just created an aquifer. An aquifer is a geologic formation (layer of sand, gravel, or rock) that stores water.

4. Have students record the volume of water that they poured into their aquifer.

5. Have students find the top of the water in the model aquifer. Explain that they have just identified the water table in their ground-water model.

6. Have students measure the height of the water from the bottom of the container to the water table.

Record this measurement. Explain that this zone is called the saturated zone. The top of this saturated zone is called the water table.

7. Have students measure from the surface of the pea-size gravel down to the water table. Explain that this zone is called the unsaturated zone.

8. Have students draw a picture of the model aquifer. Record the vertical thicknesses of the unsaturated zone and the saturated zone on the drawing.

9. Ask the students to determine the area of the model aquifer by measuring its length and width.

Rectangular container: length $(\mathrm{cm}) \mathrm{x}$ width $(\mathrm{cm})=\operatorname{area}(\mathrm{cm})^{2}$

Round container: $3.14 \times$ [radius of the cylinder $(\mathrm{cm})]^{2}=$ area $(\mathrm{cm})^{2}$ 
10. Ask students to determine the volume of the pea-size gravel. Review the concept that volume is the surface area times the third dimension (thickness). This volume can be expressed as length times width times thickness. To find the volume of the model aquifer:

Rectangular container: length $(\mathrm{cm}) \mathrm{x}$ width $(\mathrm{cm}) \mathrm{x}$ thickness $(\mathrm{cm})($ of the pea-size gravel) $=$ volume $\left(\mathrm{cm}^{3}\right)$

Round container: $3.14 \times$ [radius of the cylinder $(\mathrm{cm})]^{2} \times$ thickness $(\mathrm{cm})$ (of the pea-size gravel) $=$ volume $\left(\mathrm{cm}^{3}\right)$

11. Ask the students to find the volume of the saturated zone:

Rectangular container: length $(\mathrm{cm}) \times$ width $(\mathrm{cm}) \times$ thickness $(\mathrm{cm})$ (of saturated zone) $=$ $\left(\mathrm{cm}^{3}\right)$

Round container: $3.14 \times$ [radius of the cylinder $(\mathrm{cm})]^{2} \mathrm{x}$ thickness $(\mathrm{cm})$ (of saturated zone) $=$ $\left(\mathrm{cm}^{3}\right)$

(Remember the thickness of the saturated zone is the thickness of the pea-size gravel minus the depth to the water surface from the surface of the pea-size gravel.)

12. Introduce the term porosity. Compute the percent porosity of the model aquifer. Compare this number to the percent porosity for gravel found in the enclosed table titled "Representative Porosity Ranges for Sedimentary Materials" located on page W-18 of the Porosity lesson plan.

$$
\text { Porosity }(\%)=\frac{\text { Volume of water added to the model }(\mathrm{mL})}{\text { Total Volume of the Saturated Zone }\left(\mathrm{cm}^{3}\right)} \times 100=(\quad)
$$

NOTE: The volume of water was originally recorded at the beginning of this activity. $1 \mathrm{~cm}^{3}=1 \mathrm{~mL}$ Application Section:

Ask the students how they think WRPs measure the size of aquifers. Explain the methodology. Ask the students how they think WRPs measure the porosity of an aquifer.

Porosity can be determined in the laboratory by taking a sample of known volume. The sample is dried at $105^{\circ} \mathrm{C}$ until it reaches a constant weight. The dried sample is submerged in a known volume of water and placed in a sealed container so there will be no evaporation loss until it is saturated. The porosity is the volume of pore spaces (equal to the original water volume minus the volume of water left in the container after saturation) divided by the volume of the saturated sample.

Discuss local aquifers and their uses. If available, discuss the depth to ground water for the community where the educational event is taking place, type of aquifer that exists, the aquifer thickness, areal extent, and its porosity.

\section{Stewardship:}

Discuss the uses of ground water in the local area. Brainstorm ways to conserve ground water based upon the area's ground water uses.

\section{Careers in Water Resources:}

See the section titled Careers in Water Resources on page W-34. 


\section{U.S. DEPARTMENT OF THE INTERIOR BRUCE BABBITT, Secretary}

U.S. GEOLOGICAL SURVEY

Gordon P. Eaton, Director

The use of trade, product, industry, or firm names is for descriptive purposes only and does not imply endorsement by the U.S. Government.

For additional information write to:

Copies of this report can be purchased from:

Chief, Earth Science Education Program U.S. Geological Survey

Box 25046, MS 414

Denver Federal Center

U.S. Geological Survey

Earth Science Information Center

Open-File Reports Section

Denver, CO 80225

Box 25286, MS 517

Denver Federal Center

Denver, CO 80225 


\section{CAREERS IN WATER RESOURCES}

This section of the lesson plan is intended to allow students to ask questions concerning careers in water resources. If possible, prepare about five slides that show you or an individual you know working on a ground-water project or other water-related project. The purpose of the slide presentation is to show what you do in your career in water resources. Slides help students visualize what WRPs do.

Lead an open discussion allowing students to ask questions they may have developed concerning water resources. You may not have an answer for some of the questions you are asked. When you do not know the answer, honestly tell the student who asked the question that you do not know the answer. It is important that the students know that scientists do not have all the answers. After all, answering questions is what science is all about. Tell the student that you will try to find the answer by researching the answer or asking another scientist. This provides an opportunity to discuss how scientists work together to solve problems. Name people in your office who have greater knowledge (perhaps more experience) or specialize in certain areas such as chemistry, biology, math, computers, etc. It is very important to let students know that they need not know everything; no one can know everything. This simple fact may relieve some of the students' fears about science and encourage them to learn more. If you have promised to research an answer for a student, be sure to follow through and see that the student gets the proper answer.

Some questions, such as, "What happened to the water on Mars," do not have any specific answers, only theories. A good response to this type of question is to tell the students that the answer to the question is for future scientists, like the student who asked the question, to find out.

Finally, be prepared to answer questions concerning salaries of individuals who work in the field of water resources. 


\section{OVERVIEW OF GROUND WATER}

\section{Saturated and Unsaturated Zones}

Precipitation falls to Earth, remains on the surface, or infiltrates into the soil. Water that remains on the Earth's surface is called surface water. Water that infiltrates beneath the land surface becomes ground water. Ground water is stored and flows in the pore spaces between rock materials and in solution openings and fractures in some types of rocks. The ability of rock material to store water is known as porosity. Porosity is measured as a ratio of openings in the rock material to the total volume of rock material and is usually described as a percentage. (See Figure WRP-12.)

Fresh water is critical to many living organisms, yet only 3 percent of the water on Earth is fresh water. There are two main sources of fresh water: surface water and ground water. Surface water flows over the land surface in rivers, streams, and lakes. Ground water exists beneath the surface of the Earth, making it a hidden resource. Ground water makes up about 95 percent of the fresh-water resources in the United States.

Ground water is water beneath the Earth's land surface, filling pores (open spaces) and fractures in geologic formations. Ground water can be collected by pumping from wells or may be found flowing naturally to the surface at springs. It can sustain the flow of rivers and streams during dry periods or be a source of water flowing into lakes, ponds, or wetlands. Nationally, about $40 \%$ of municipal, domestic, and agricultural water is supplied by ground water. The following discussion is a refresher on the basic terminology and physical processes associated with ground water.

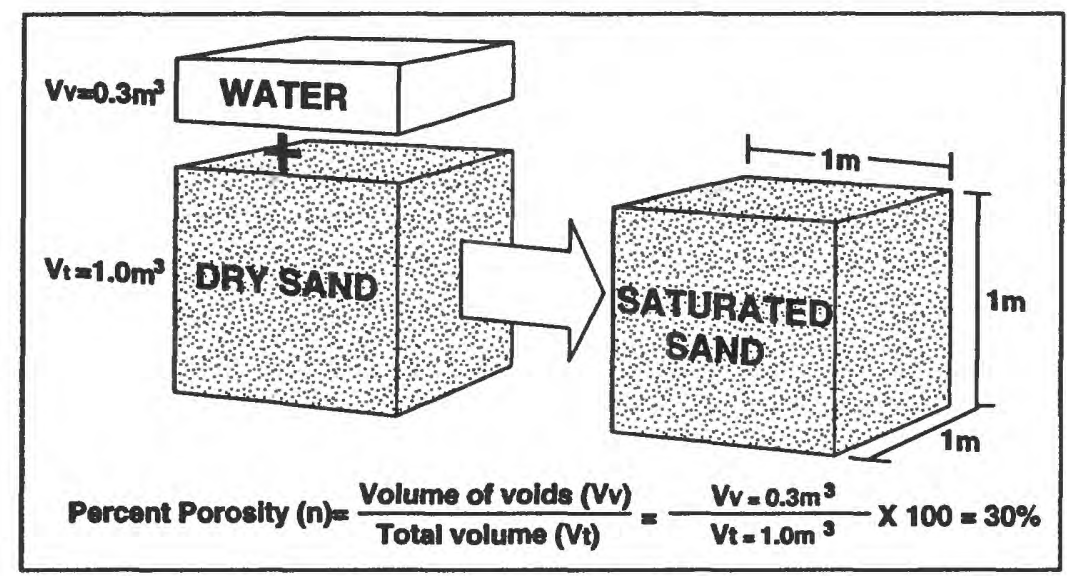

Figure WRP-12. Porosity.

Porosity of loosely arranged (unconsolidated) rock materials such as sand and gravel depends on the range in particle size (sorting) and on the shape of the rock particles. In nature, layers of loosely arranged rock materials of fairly uniform size (such as sand) tend to have a greater percent porosity than layers of loosely arranged rock materials containing materials of different sizes. This is because the smaller rock materials tend to settle in the pore spaces between larger rock materials, decreasing the amount of open space (or porosity). In other words, if the loosely arranged rock materials that make up underground rock layers are all about the same size (a well-sorted material), the pore spaces between the materials account for a larger percentage of the whole volume. In addition to particle-size sorting, the porosity of sediments is affected by the shape of the particles. Particles with a spherical shape will pack more tightly than particles with angular edges, resulting in a greater porosity for angular-shaped particles. 
Ground water occurs below the land surface in two different zones. The unsaturated zone is immediately below the land surface and contains water and air. The unsaturated zone is almost always underlain by a zone in which all the pores and fractures are full of water, the saturated zone. The top of the saturated zone is called the water table (see Figure WRP-13). The water table may be just below the land surface or hundreds of meters below the land surface.

If underground rock materials are capable of storing and transmitting water in useful amounts, the rock materials are called an aquifer. Underground rock materials such as clay or unfractured crystalline rock that restrict the flow of water are not aquifers but are confining materials.

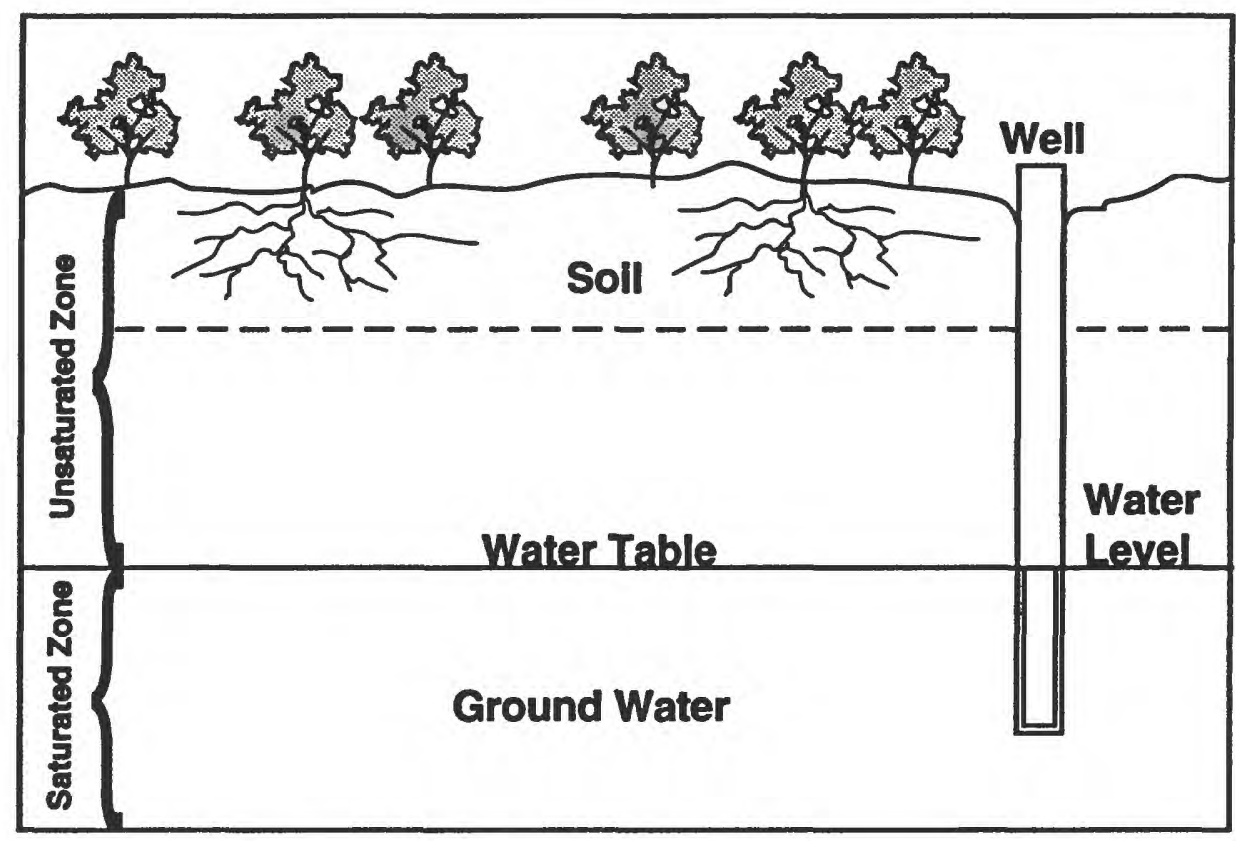

Flgure WRP-13. Unconfined Aquifer. 
If water is to move through underground rock materials, pore spaces or fractures must be connected to one another. If the pore spaces or fractures are not connected, the rock material will not yield water and will act as a confining material and not an aquifer. If rock materials have good connections between pore spaces or fractures and water can move freely through them, we say that the rock is permeable. Permeability refers to the capability of a material to transmit water (see Figure WRP-14).

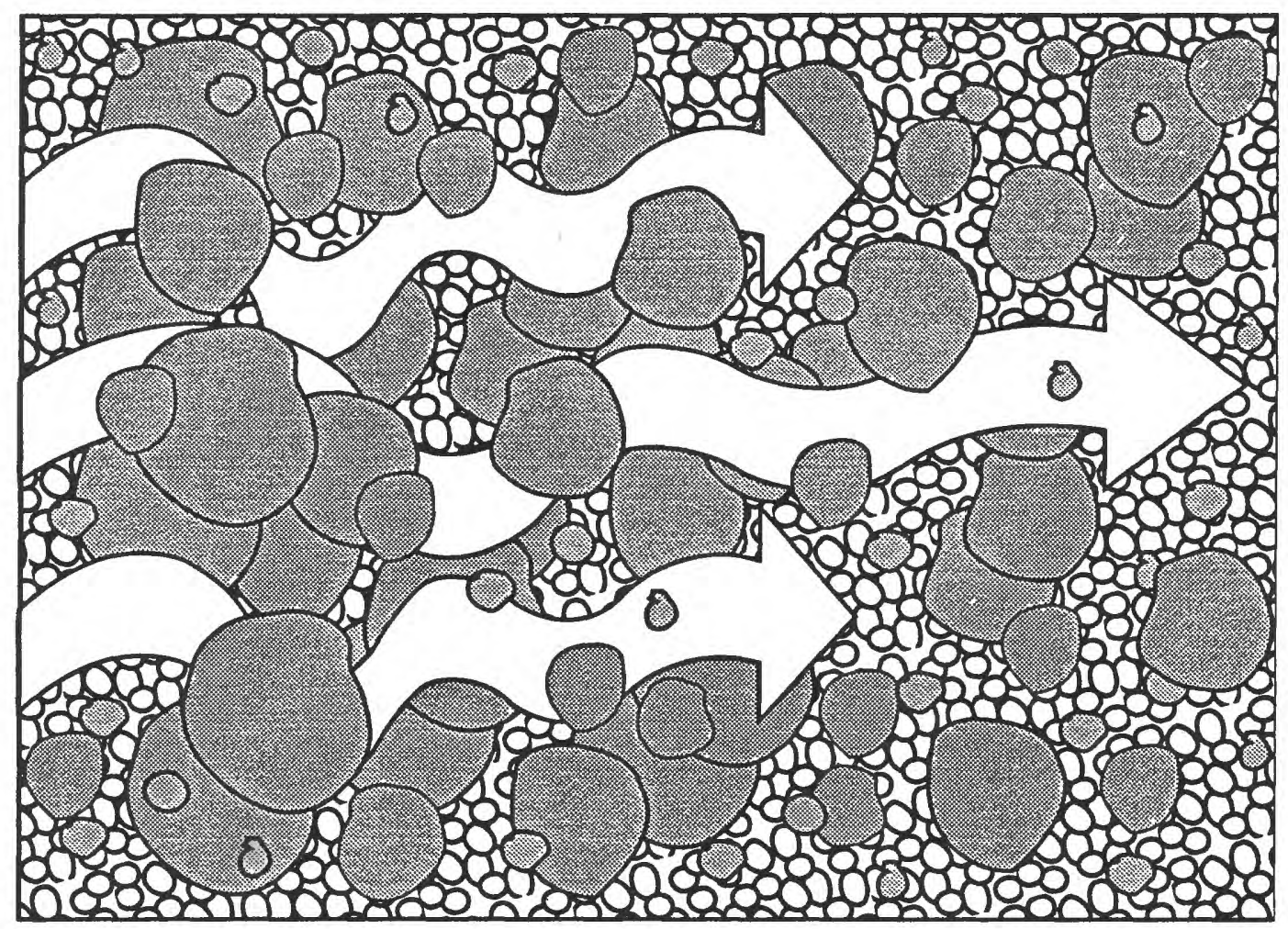

Figure WRP-14. Permeability.

Ground water occurs in the saturated zone under two different conditions. One condition exists where water completely fills an aquifer and the aquifer is overlain by a confining bed. Such aquifers are referred to as confined or artesian aquifers.

Wells completed in a confined aquifer are referred to as artesian wells. The water level in an artesian well is located at a height above the top of the aquifer, indicating that the water in the confined aquifer is under pressure (see Figure WRP-15). The water level is termed the potentiometric surface. In some instances the height of the water level in an artesian well may rise above land surface. In this instance the well is a flowing artesian well.

The second condition exists where the saturated zone only partly fills an aquifer. As the water continues to move through the saturated zone, the water table is free to rise and fall. Water in such aquifers is said to be unconfined, and hence the aquifer is called an unconfined or water-table aquifer. Water levels of wells placed into a water-table aquifer indicate the position of the water table in the aquifer (see Figure WRP-15).

The volume of water that an aquifer can hold depends upon the volume of the underground rock materials and the size and amount of pores and fractures that can be filled with water. An aquifer may be only one meter or thousands of meters thick. It may be less than a square kilometer in area or hundreds of thousands of square kilometers in area. For example, the High Plains Aquifer underlies about 450,000 square 
kilometers in parts of eight States -- Colorado, Kansas, Nebraska, New Mexico, Oklahoma, South Dakota, Texas, and Wyoming.

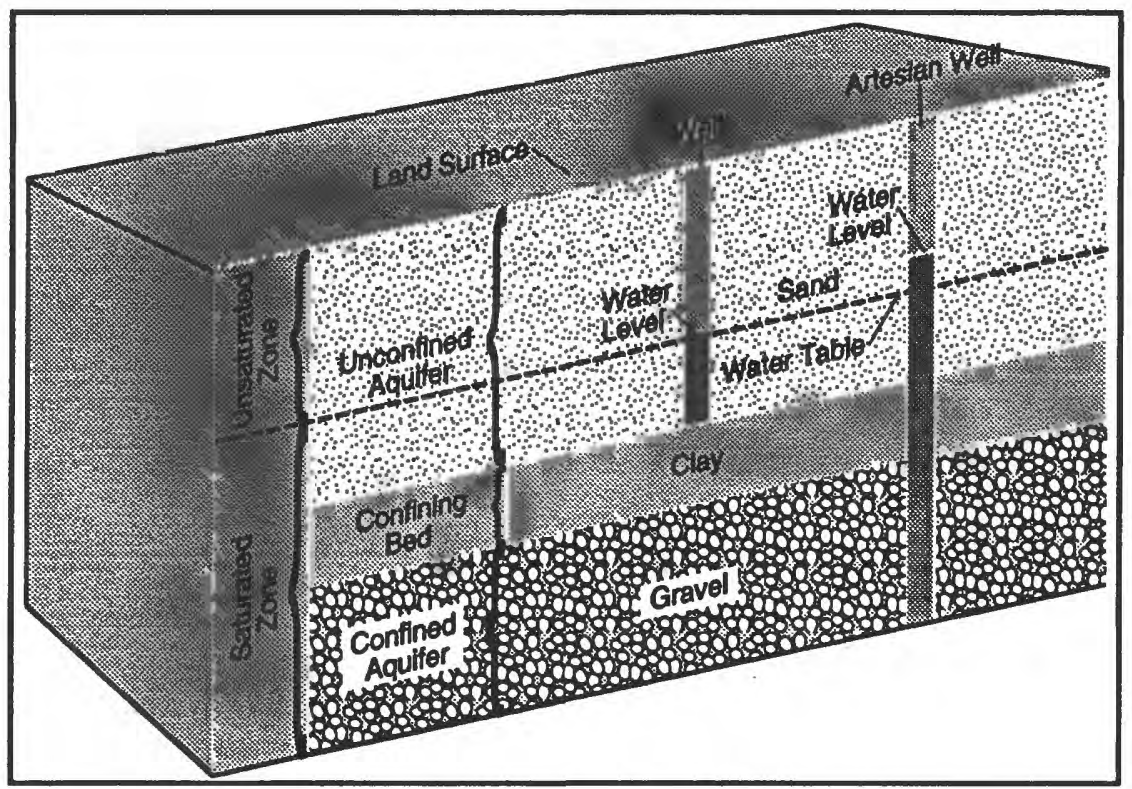

Figure WRP-15. Confined and Unconfined Aquifers.

Aquifers receive water from precipitation that infiltrates down through the unsaturated zone and directly from some surface-water bodies such as lakes, streams, or rivers. Areas where infiltration to aquifers occurs are commonly referred to as recharge areas.

Where the land surface intersects the water table or potentiometric surface, water stored in the aquifer can flow at the land surface as a spring or seep. Most surface-water bodies such as rivers, ponds, and wetlands obtain most or part of their water from ground water. The water level of some ponds and wetlands can be an extension of the local water table or potentiometric surface. Locations where ground water flows or is discharged to the land surface or to surface-water bodies are referred to as discharge areas.

Ground water also can be brought to the surface by pumping from a well or can naturally flow out of the ground where the water table comes in contact with the land surface (for example a spring). A well is an opening that was drilled or dug into the aquifer (see Figure WRP-16). Water from the aquifer will flow into this opening to replace water removed from the borehole by a pump. Where materials that comprise the aquifer would fall into the well and tend to fill the well opening, the aquifer materials need to be supported with a pipe or "well casing." Perforations in the well casing are placed below the water table or potentiometric surface, allowing water to flow into the well. 


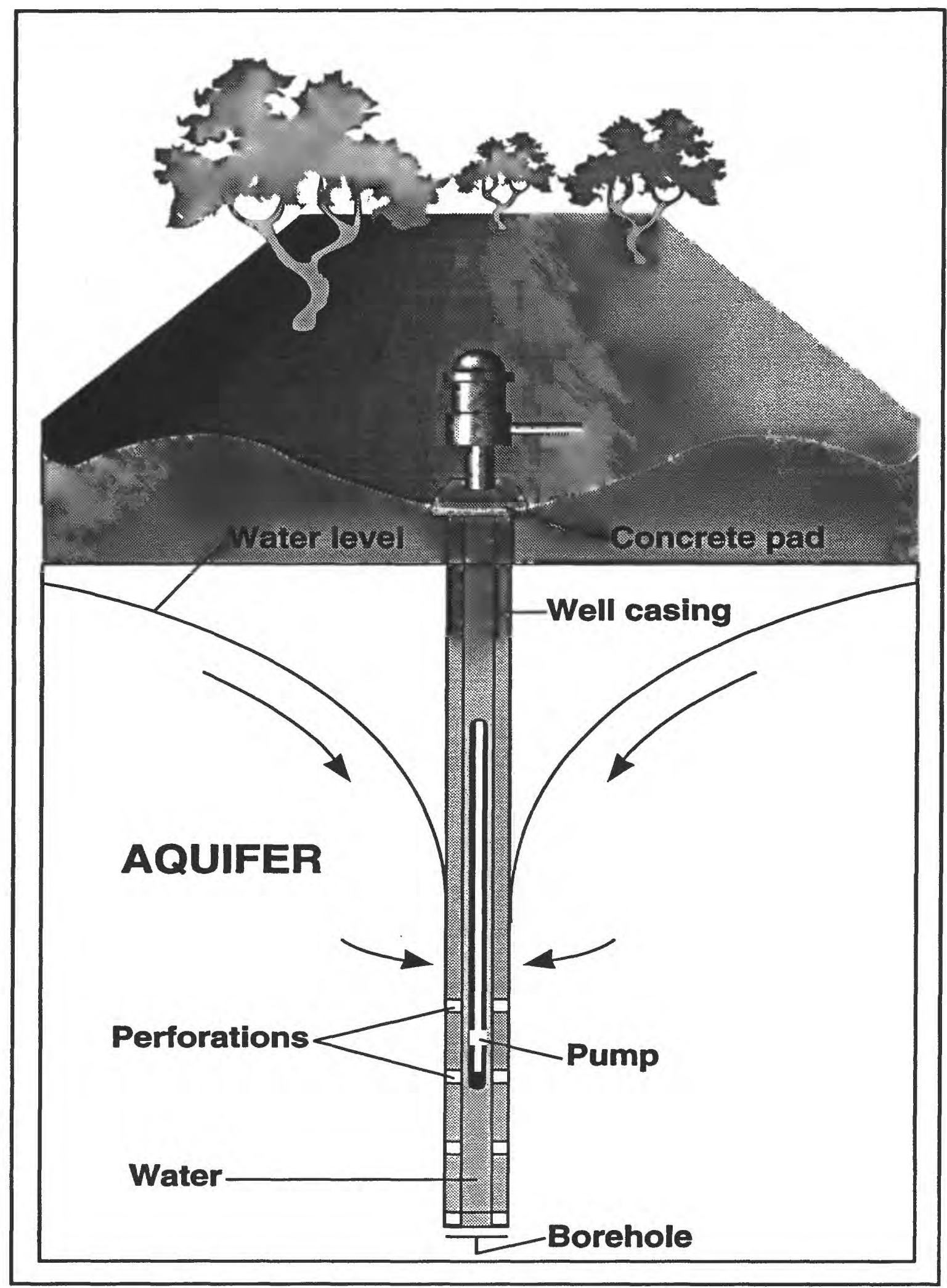

Flgure WRP-16. Inside a Well. 
Water moves from areas of recharge to areas of discharge through the saturated zone. Recharge areas are higher in elevation than discharge areas. Recharge, movement, and discharge of ground water are reflected in the elevation of the water table or potentiometric surface.

Surface water and ground water are integral to the hydrologic cycle. When surface water infiltrates the ground and percolates downward to the water table, it becomes part of the ground water system. If the surface water recharging an aquifer is polluted, it will become contaminated ground water. In addition, contaminated ground water can affect the quality of surface water at discharge areas.

The movement of ground water from recharge to discharge areas is displayed on an educational poster titled "Ground Water: The Hidden Resource." An unconfined ground-water system is depicted in cartoon format. The reverse side of the full-color poster contains educational activities, one version for students in grades 3-5 and the other with activities for students in grades 6-8. This poster is available at no cost by writing to:

\author{
U.S. Geological Survey \\ Box 25286 \\ Denver Federal Center \\ Denver, CO 80225
}

When ordering, specify the version of the poster (grade school for grades 3-5 or middle school for grades 6-8) you desire.

\title{
Hydrologic Cycle and Ground Water
}

The hydrologic cycle is the constant movement of water above, on, and below the Earth's surface. It does not have a beginning or end. Even so, it is convenient to discuss the principal features of the hydrologic cycle by starting with evaporation. Evaporation is the process whereby liquid or solid water is converted to vapor from water surfaces such as the ocean, lakes, rivers, and ice, that together with transpiration from plants rises above the Earth's surface, condenses, and forms clouds. The water in the clouds returns to the land surface or water surfaces in the form of precipitation.

Precipitation occurs in several forms, including rain, snow, and hail, but only rain is considered in this discussion. The beginning of a storm or precipitation event wets the ground surface. As additional rain falls, water begins to infiltrate into the ground. Infiltration rates vary widely, depending upon soil type, land use, the character and moisture content of the soil, and the intensity and length of the storm. Water can infiltrate faster into sandy soils than clayey or silty soils. The infiltration rate in paved areas is almost zero. When and if the rate of precipitation exceeds the rate of infiltration, runoff, or overland flow, occurs.

Initially, the infiltrating water increases the soil moisture. When the soil is completely saturated, the additional infiltration percolates slowly down through the unsaturated zone to the saturated zone. This water recharges (adds) to the ground water in the saturated zone of the aquifer. Water in the saturated zone moves to areas of ground-water discharge.

Water, both from runoff and from ground water discharge, moves toward streams and rivers, and may eventually reach the ocean. Water evaporates from surface-water bodies or is transpired from vegetation to continue the cycle. Of course, oceans are the largest surface-water bodies that contribute water through evaporation to the hydrologic cycle. Movement of water is the key element in the hydrologic cycle.

For use in the Pre-Visit part of the lesson plans, the following two diagrams WRP-17 and WRP-18 are provided to assist the instructor in introducing the hydrologic cycle to the students. 


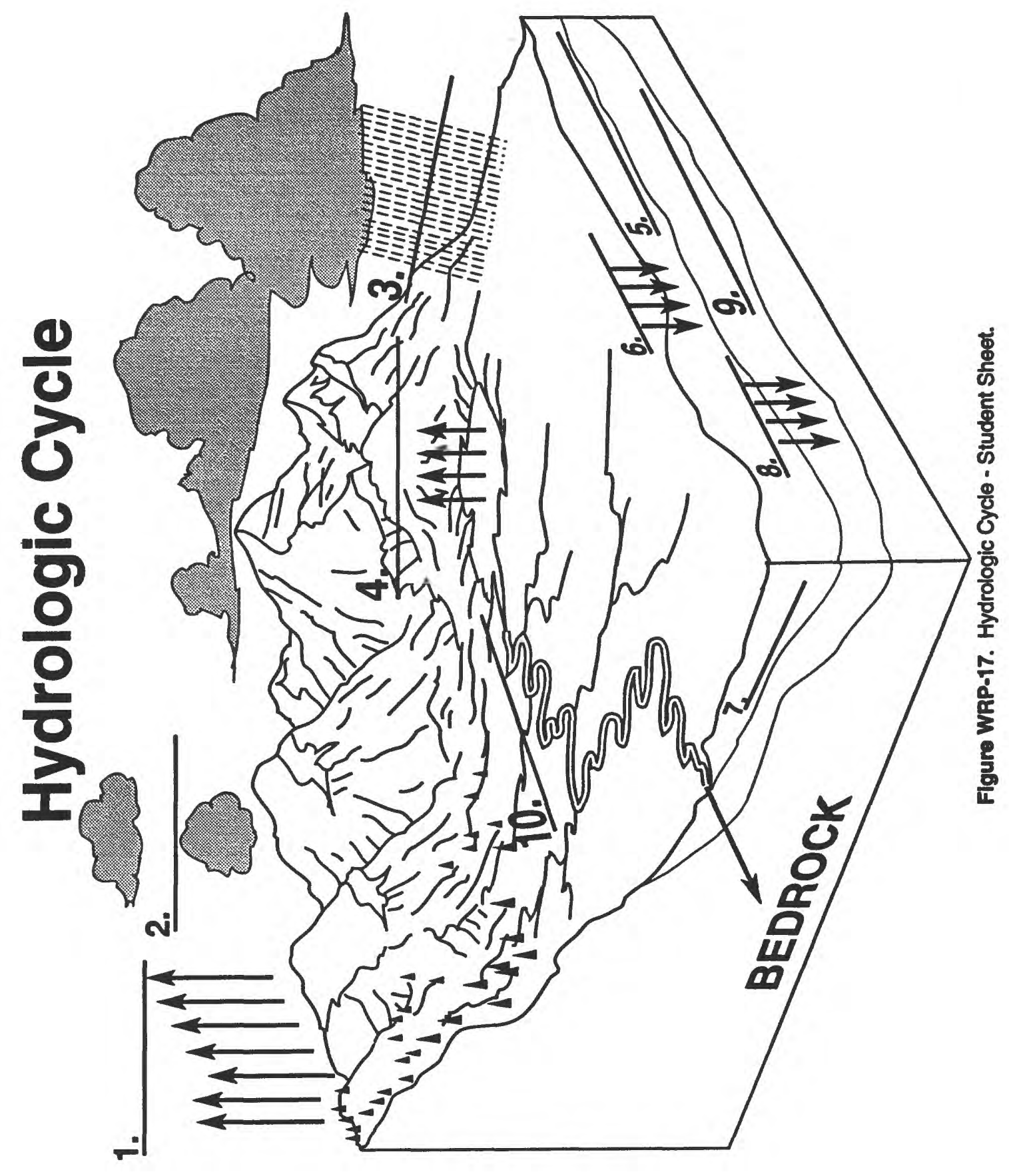




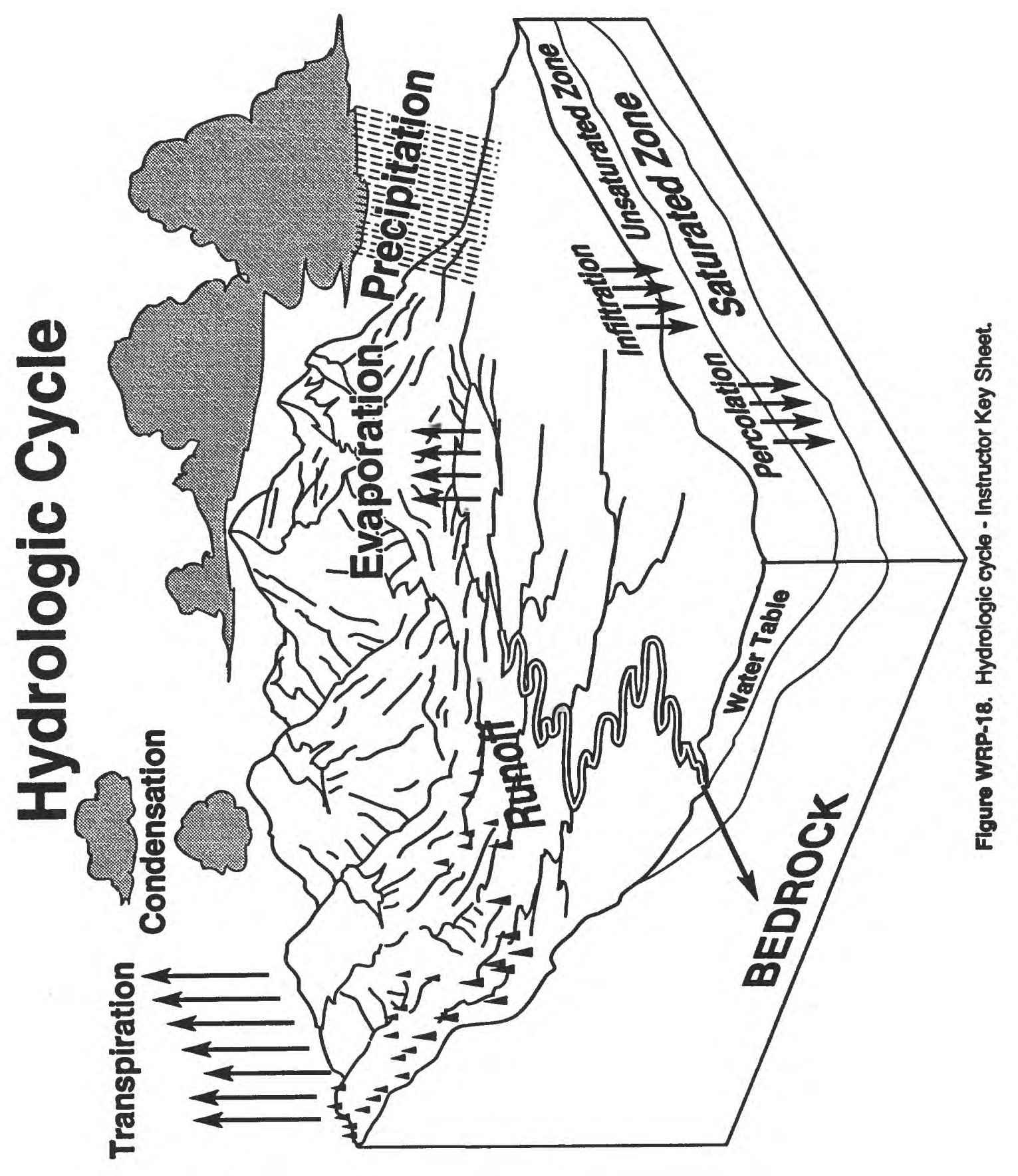




\section{GLOSSARY}

The following terms have been defined in terminology understandable to students in grades 6-8. Scientific terms can be a foreign language to students, hindering the most important part of science educationunderstanding scientific principles and concepts. When using scientific terms, it is important to use proper definitions of terms that are understandable to the audience (6-8 grade students). The following definitions are the result of combined work of water resources professionals and practicing teachers in grades 6-8 to ensure understanding by students in grades 6-8. It is recommended that both the water resources professional and instructor use these definitions when conducting the lessons.

AQUIFER: An underground layer of porous sand, gravel or fractured rock capable of storing and supplying water to a well or spring.

ARTESIAN AQUIFER (same as confined aquifer): An aquifer completely filled with water overlain by a confining layer. Because water is under greater than atmospheric pressure at the top of the aquifer, water levels in wells located in the aquifer rise above the top of the aquifer.

ARTESIAN WELL: A well drilled into an artesian aquifer. Water in the well rises above the top of the aquifer.

BENEFICIAL USE OF WATER: The use of water for purposes such as domestic, livestock, irrigation, recreation, fish and wildlife, fire protection, power, industrial use, etc.

CONFINING BED (Same as confining layer): A layer of rock material that restricts the flow of water.

CONFINED AQUIFER: See artesian aquifer.

CONSERVATION: To protect from loss and waste.

CONSUMPTIVE USE: A use of water where a part is used up and no longer immediately available for use or reuse.

CUBIC FOOT PER SECOND (cfs) $\left(\mathrm{ft}^{3} / \mathrm{s}\right)$ : A cubic foot of water moving 1 foot in 1 second. A term used in the measurement of the volume of streamflow.

DRAWDOWN: The lowering of the water level in an aquifer caused by the discharge of water.

EVAPORATION: The process by which liquid or solid water becomes vapor.

EVAPOTRANSPIRATION: Loss of water from land areas by evaporation from soil and plant surfaces, and transpiration of water by plants.

FLOW: The volume of water moving past a point during a specified time. Also known as discharge.

GROUND WATER: Water beneath the land surface.

GROUND-WATER DISCHARGE: The flow or pumping of water from an aquifer.

GROUND-WATER RECHARGE: The addition of water to an aquifer.

HYDROLOGIC CYCLE (water cycle): The continuous movement of water from the ocean to the atmosphere, to the land, and back to the ocean. The hydrologic cycle has no beginning or end.

IMPERVIOUS: Resistant to penetration by water or plant roots.

INFILTRATION: Movement of water from land surface into the soil.

PERCOLATION: The movement of water through the subsurface soil layers, usually continuing downward into the saturated zone.

PERMEABILITY: The capability of porous soil or rock for transmitting water.

POLLUTION: Contamination from human activities that restricts the uses of water.

PORE SPACE: That portion of rock or soil not occupied by solid mineral matter and that may be occupied by ground water or other liquids or gases.

POROSITY: The volume of pore spaces in a rock or layer of earth materials divided by the total volume of rock and expressed as a percent.

POTENTIOMETRIC SURFACE: A surface that represents the level to which water will rise in a well.

PRECIPITATION: Rain, snow, mist, sleet, or hail.

RAIN: Water drops that are heavy enough to fall to earth from the air.

RAINFALL: The quantity of water that falls as rain only.

RUNOFF: The portion of rainfall, melted snow, or irrigation water that flows across the land surface and eventually flows into streams, lakes, or the oceans.

SATURATED ZONE: Zone below the land surface where all pores or fractures are filled with water.

SOIL MOISTURE: Water partially filling some pores in the soil.

SPECIFIC YIELD: The volume of water that can be drained by gravity from the pores of sand, gravel, soil, or rock divided by the total volume of material and expressed as a percent. 


\section{PREFACE}

The following materials have been developed for educational outreach by a team consisting of an instructor (school teacher, Girl or Boy Scout leader, 4-H counselor, etc.) and a water resources professional (WRP). This notebook provides a mechanism whereby an individual employed in a scientific field associated with water resources assists an instructor in the presentation of water-resources science to encourage more students to pursue careers in science and engineering.

The educational materials in this notebook are unique in that they require instructors and a WRP to work together. The notebook contains five lesson plans and is divided into two sections, one for the instructor and one for the WRP.

After initial contact, the WRP provides a copy of the Instructor Section to the instructor. The instructor selects the lesson plan that complements the curriculum he or she is teaching from the instructor's section of the notebook. The instructor and WRP discuss the responsibilities and materials required for the selected lesson plan. Prior to the visit by the WRP, the instructor completes the pre-visit portion of the selected lesson plan. Then the WRP attends the educational event to conduct the hands-on activity outlined in the selected lesson plan and discusses application of the lesson-plan topic to a water-resources career. Follow-up activities are available for use by the instructor to further emphasize the topic presented in the lesson plan. Evaluation forms for students, instructors, and WRPs are located in the WRP Section, beginning on p.W-45.

All participants (students, instructors, and WRPs) involved have the potential to benefit from using the materials in this notebook. Information from the lesson plans in this notebook provides students with the opportunity to learn more about water resources and how this knowledge is applied in the "real world" from a practicing WRP. WRPs provide role models for students and an opportunity for students to learn about careers in water resources. Also, instructors have a partner (the WRP) in the field of water resources to contact concerning water-resources questions. WRPs gain experience in working with today's youth and obtain an appreciation of instructors and the teaching community. 
SURFACE WATER: Water on land surface such as oceans, streams, lakes, etc.

UNCONFINED AQUIFER: An aquifer whose upper water surface (water table) is at atmospheric pressure and is free to rise and fall.

UNSATURATED ZONE: The zone, which usually occurs immediately below the land surface, where the pores or fractures contain both water and air.

WATER CYCLE: See Hydrologic Cycle.

WATER QUALITY: A term used to describe the chemical, physical, and biological characteristics of water.

WATER TABLE: The top of the water surface in the saturated zone of an unconfined aquifer.

WELL: A pit, hole, or shaft sunk into the earth to observe or tap an underground supply of water. 


\section{EVALUATION FORMS}

The following evaluation forms, one each for the instructor, student, and WRP, should be completed after every educational visit. The WRP should present blank copies of the Instructor Evaluation and Student Evaluation to the instructor at the educational visit. 


\section{Water Resources Professional Evaluation Form}

1. Which activity did you use?

2. How many presentations did you do?

3. Were the instructions for the activity clear?

Yes

No

4. If not, what are your suggestions for changes?

5. Do you think the activity taught the intended concepts?

Yes

No

What would you change?

6. How easy was it for you to get materials and community aquifer data for the activity? (If they were provided for you, please indicate.)

Easy

Difficult (wouldn't want to do on my own)

$\underline{\text { Materials }}$

1

2

3

4

5

Community Data

1

2

3

4

5

7. How well do you think your presentation was received by the students?

Well received

Poorly received

1

2

3

4

5

8. Was the success of the presentation due to:

the activity?

$$
\text { your }
$$


9. Would you feel comfortable doing more presentations from this project?

10. Comments:

11. WRP Information:

Name

Agency/Company Name

Address

City, State ZIP

Please send evaluations to:

Water Resources Education Initiative

U.S. Geological Survey

P.O. Box 25046, MS 414

Denver, CO 80225 


\section{Instructor Evaluation Form}

PART 1: RATE THE LESSON PLAN PRESENTED

1. Which lesson plan did you choose?

2. Number of students attending the educational visit:

3. Did you introduce the lesson plan topic to your class prior to the visit?

Yes No

4. Did you use the suggested pre-visit activity with your class?

Yes No

5. If you used the pre-visit activity, how would you rate it?

Excellent

1
2

3
4

Poor 5

6. Was the lesson plan well organized?

Very 1
2
3
4

Not at all 5

7. Was this activity/presentation appropriate to your grade level?

2

8. After observing how the water resources professional did the activity with the students, how comfortable do you feel about doing this same or a similar activity with your student?

$$
\text { Very }
$$

1
2
3 Yes
Not at all

4

9. Will you use any of the additional activities?

No 
10. What suggestions do you have for changes to the additional activities?

11. Did your students show interest in finding out more information related to the presentation/activity? Yes No

12. Was the success/failure of the presentation due mainly to: activity? presenter? both? other? (please explain) 


\section{PART 2: RATE THE WATER RESOURCES PROFESSIONAL USE OF THE LESSON PLAN}

13. Was he/she knowledgeable about the subject?

Very

1

2

3

Not at all

4

5

14. Was he/she receptive to discussion and questions?

Very

1

2

3

4

Not at all

5

Yes

No

Not sure

16. Did he/she seem comfortable being the presenter?

Very

1

2

3

4

Not at all

5

17. Rate your students' response to the presentation:

Excellent

1

2

3

4

Poor

18. Would you invite the presenter back for another session?

Yes

No

19. Comments: (use additional sheet if necessary)

20. Instructor Information:

Name

School/Educational Event Name

Address

City, State ZIP

Please send both the instructor and student evaluations to:

Water Resources Education Initiative

U.S. Geological Survey

P.O. Box 25046, MS 414

Denver, CO 80225 


\section{Student Evaluation Form}

1. Did your instructor do a related activity to introduce the topic before the water resources professional came to your class?

Yes $\quad$ No

2. Did you enjoy the activity the water resources professional did with your class?

Yes

No

3. How much did you learn from this activity and presentation?

Quite a lot

2

3

4

Very little

5

4. Do you believe that the presentation was a success or failure? Circle one:

Success

Failure

5. Circle what you think was the reason(s) for the success/failure of the presentation.

the water resources professional? the activity? both? something else?

(please describe)

6. How interested are you in learning more about the information in the presentation?

Very interested

1

2

3

4

Not very interested

7. Did the water resources professional raise your interest in a career in some field related to the use/study of water?

Yes

No

8. What did you like best about the presentation?

9. Comments: 



\section{INSTRUCTOR SECTION}




\section{CONTENTS}

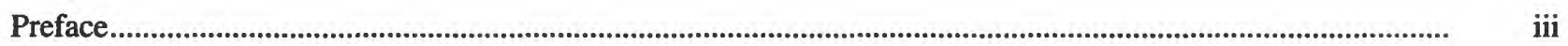

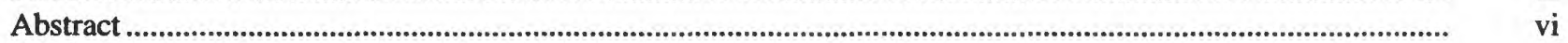

\section{Water Resources Professional Section}

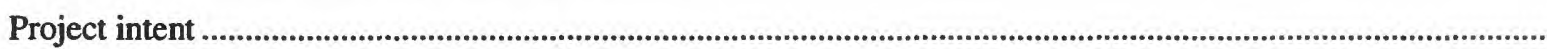

Philosophy.

Using the notebook

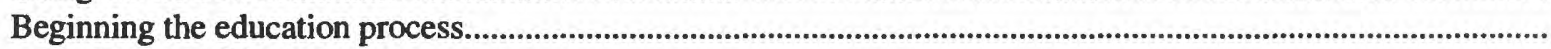

Responsibilities

Instructor's responsibilities .............................................................................................................................

Water resources professional's responsibilities.........................................................................................

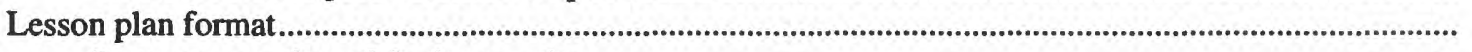

Instructor section of the lesson plan.............................................................................................. W-4

Water resources professional section of the lesson plan ..................................................................... W- W

Water resources professional's checklist.................................................................................................. W-5

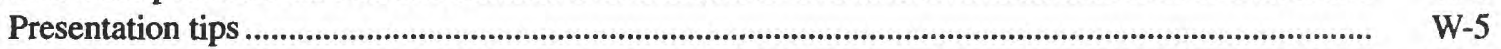

Materials needed for all water resources professional lesson plans................................................................. W

Lesson plans .................................................................................................................................................. W

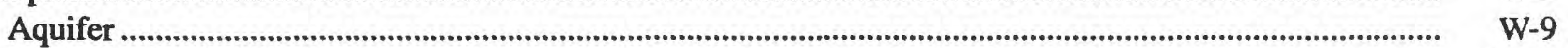

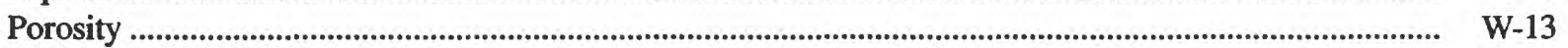

Permeability ............................................................................................................................................. W-19

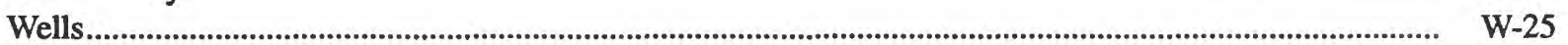

Calculations ........................................................................................................................................ W-30

Careers in water resources ........................................................................................................................................ W-34

Overview of ground water ........................................................................................................................... W-35

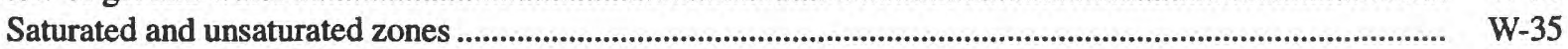

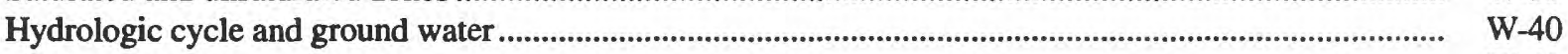

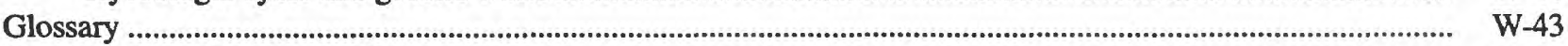

Evaluation forms

\section{Instructor Section}

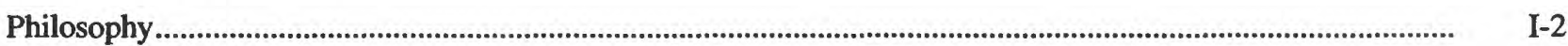

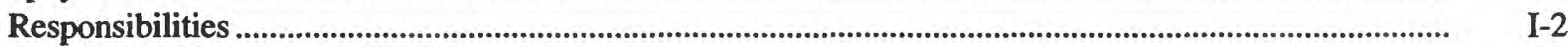

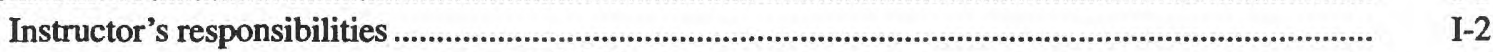

Water resources professional's responsibilities................................................................................. I-3

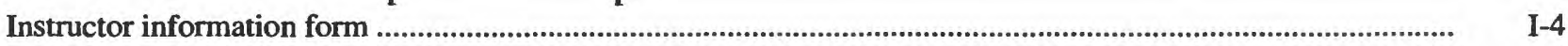

Lesson plan format........................................................................................................................... I

Instructor section of the lesson plan................................................................................................... I-5

Lesson plan summaries

Water resources professional section of the lesson plan ................................................................ I-5

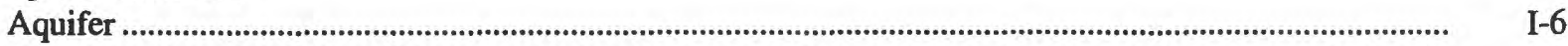

Porosity ................................................................................................................................................... I I-8

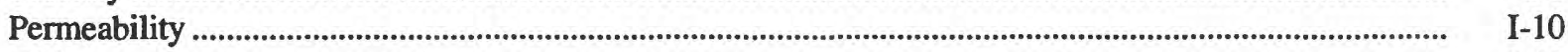

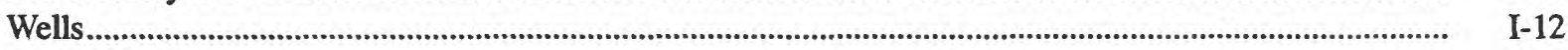

Calculations......................................................................................................................................... I-14

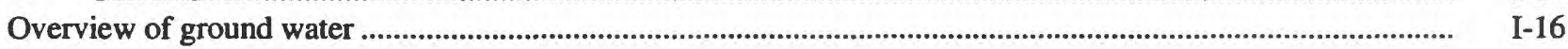

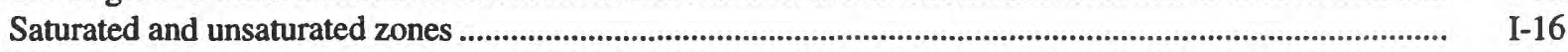

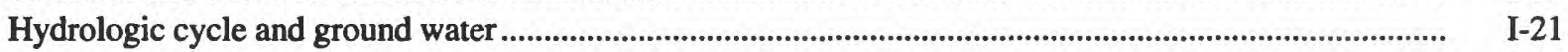

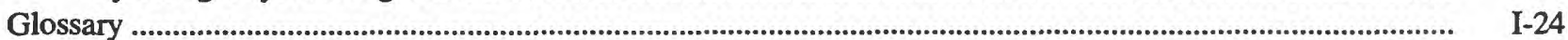




\section{PHILOSOPHY}

Educating today's youth concerning the science of water resources should not be the sole province of educational instructors. Water Resources Professionals (WRPs) can provide a valuable service by sharing technical knowledge of water resources with students and instructors. Meeting and talking with a WRP can help students make a connection with science. Many students view a WRP in a stereotypical manner; a white male wearing dark-rimmed glasses, a thin tie, and a white lab coat. By making a presentation at an educational event, a WRP is able to negate this stereotypical view. Owing to their professional experiences, a WRP can credibly apply water resources science to real-life situations. Helping students to realize that the information they are learning has important applications in the "real" world is a crucial educational step.

The Instructor Section provides lesson plan summaries addressing five ground water topics. From these lesson plan summaries, the instructor selects the lesson plan topic for presentation at the educational visit. The instructor completes the pre-visit activity and follow-up discussion. The WRP conducts handson activities with the students and discusses the application of the lesson plan topic to his or her career. To help facilitate the working relationship, a list of responsibilities for the instructor and WRP, Instructor Information Form, and lesson plan format are provided. Also included is an Overview of Ground Water and a Glossary to provide information about ground-water science. Follow-up activities on the topic of ground water and a list of selected ground-water educational references can be provided upon request from the WRP.

\section{Responsibilities}

The following responsibilities outline a framework to enhance the learning opportunity provided by a WRP when an educational visit is made by the WRP. To implement this framework, direct communications need to take place between the instructor and the WRP. Part of this communication includes the division of certain responsibilities, which are listed below.

\section{Instructor's Responsibilities}

1. Communicate with the WRP concerning your knowledge of water resources. Feel free to ask any questions. This is part of the program.

2. Read the Instructor Section thoroughly.

3. Select lesson plan(s) to be taught by the instructor and the WRP.

4. Complete the Instructor Information Form on page I-4 and promptly return it to the WRP.

5. Complete the pre-visit orientation part of the selected lesson plan with your students.

6. Divide the students into working groups. Appoint a group leader, a group note keeper, and a group supply person. An additional member can be included in a group if there are more than 30 students in a class. The group supply person is responsible for obtaining the materials from the WRP. WRP must be notified and special arrangements made if there are more than 10 groups.

7. Be present during the presentation by the WRP to learn, facilitate, assist, and deal with discipline problems that may arise.

8. Complete the Instructor Evaluation and Student Evaluations after the visit. 


\section{Water Resources Professional's Responsibilities}

1. Send a copy of the Instructor Section of the notebook to the instructor immediately after he or she first contacts you. Be sure to fill out your name, address, and phone number at the bottom of the Instructor Information Form located in the Instructor Section on page I-4.

2. After you receive the completed Instructor Information Form back from the instructor, contact the instructor. Ask if they have any questions about ground water or the lesson plan(s) to be presented. Discuss the materials needed for the hands-on activity that the instructor and you have agreed upon. (You may need to supply all the materials or just a few.) Discuss the items on the WRP Checklist with the instructor.

3. If requested by the instructor, send a copy of the follow-up activities and selected references to the instructor.

4. Be on time. (Allow a few minutes for setup.) If the presentation is done at a school, check in at the school office to let school officials know who you are, why you are in the building, and the name of the instructor with whom you will be working.

5. Cleanup after the activity.

6. Provide instructor with Instructor Evaluation and Student Evaluation sheets. Complete the WRP Evaluation sheet. 


\section{INSTRUCTOR INFORMATION FORM}

TO BE COMPLETED BY INSTRUCTOR

Instructor Name:

School/Organization Name:

Address:

Grade:

Room Number:

Phone:

Date and time of presentation:

Arrival time:

Departure time:

Amount of time for presentation:

Title of lesson plan to be presented:

Number of students:

Number of groups:

Directions to location of the visit:

Do you want the follow-up activities and selected references?

Yes

No

Notes:

TO BE COMPLETED BY WRP

In order to confirm a visit, return this form to the Water Resources Professional (WRP)

WRP Name

Telephone 


\section{LESSON PLAN FORMAT}

\section{Instructor Section of the Lesson Plan}

Summary/Synopsis - Presents a one-paragraph summary of the lesson plan, designed to assist the instructor in selecting the appropriate lesson plan.

Objectives - States what the students will be doing.

Materials - List of materials required to conduct the hands-on activities presented by the WRP.

Pre-Visit Orientation - Provides students with background information on ground water, allows the instructor to stimulate the students' interests, and leads them to develop ideas and questions concerning the water-resources topic discussed under the Objectives section.

Follow-up - Additional activities for use by the instructor after the WRP's visit.

\section{WRP Section of the Lesson Plan}

Summary/Synopsis - Presents a one-paragraph summary of the lesson plan.

Objectives - States what the students will be doing.

Getting Started - Lists the materials and setup requirements necessary for the Ice Breaker and Activity to be presented by the WRP.

Preparation - Preparation required before the educational event.

Ice Breaker - Consists of a demonstration, questions, or dialogue to assist the WRP in developing a rapport with the students.

Activity - Describes the hands-on activity and procedures necessary for completion of the activity for the WRP. The activity will demonstrate an important ground-water property or process. Any data needed for the activity will be supplied for the local area by the WRP.

Application - WRP discusses how the ground-water property or process presented through the activity is applied in the WRP's job. Slides, pictures, reports, data from the area, and other handouts can be used by the WRP to demonstrate the application.

Stewardship - Provides the WRP with environmental stewardship ideas to discuss with the students.

Careers in Water Resources - The WRP discusses his or her career in water resources, including education required, salary, and job duties. Encourage students to ask any questions concerning water and provide them with examples of the application of science to "real-world" situations. 


\section{LESSON PLAN SUMMARY}

\section{Topic: Aquifer}

\section{Summary/Synopsis:}

This lesson plan explains how water is stored below land surface in layers of sand, gravel, and rock (all geologic formations). It demonstrates the meaning of the terms ground water, porosity, aquifer, and water table. Confined and unconfined aquifers will be discussed. After completing this lesson, students will have a better under-standing of underground water storage and the adverse effects of overuse of this valuable natural resource.

Objectives - - The students will:

1. Discuss the uses of ground water in their community.

2. Create an aquifer model and view the saturated and unsaturated zones of the aquifer.

3. Create a lake in the aquifer model and observe the connection between surface water and ground water.

4. Be introduced, through model demonstration, to two different kinds of aquifers, confined and unconfined.

Pre-Visit Orientation - - To be completed by the instructor:

Review the hydrologic cycle with your students, placing emphasis on the infiltration and percolation of water into and through the ground. Use diagrams and information from textbooks, resource agency, or the Overview of Ground Water section.

Read the Overview of Ground Water section. Present the information in the Overview section to your students prior to the visit by the WRP. Acquaint students with the following terms described in the Overview section: hydrologic cycle, ground water, surface water, aquifer, porosity, infiltration, percolation, and permeability.

Divide the students into groups as discussed under the Instructor Responsibilities on page I-2.

Materials - - For hands-on activity:

The following list of materials is required for completion of this activity. The WRP can provide materials that are not available to you.

1. One 266-mL (9-oz) clear plastic cup for each group.

2. One resealable plastic sandwich bag filled with $3 / 4$ cup of dry, pea-size gravel for each group.

3. One 100-mL (3.4-oz) graduated cylinder for each group.

4. One small bottle of blue food coloring.

5. One grease pencil for each group.

6. 3.8 liters ( 1 gallon) of water.

7. Three large sponges for cleanup.

8. Five slides chosen by the WRP displaying work being done on a ground water project or other waterresources-related project for Careers in Water Resources part of lesson plan (optional).

9. Slide projector (optional). 
NOTE: This activity has been developed for small groups of students. Number of groups is limited to 10 or less. If this activity is to be conducted with more than one class in succession, replace the wet materials with dry materials for each group.

Follow-up Discussion - -To be completed by the instructor:

Review the concept of aquifers discussed by the visiting WRP. You may want to try some of the additional ground-water activities available from the WRP or obtain additional educational materials from the selected references. 


\section{Topic: Porosity}

\section{Summary/Synopsis:}

Ground water is the source from which we obtain much of the water that we use at home, school, and work. This water is stored in spaces between particles of sand and gravel and in fractures or spaces in rock. The water-holding capacity of Earth materials is called porosity. The layer of sand, gravel, or rock that contains water is called an aquifer.

Objectives - -The students will:

1. Discuss the uses of ground water in the community.

2. Create an aquifer model and view how water is stored in the pore spaces of the materials that compose an aquifer.

3. Create two different aquifer models and compare porosities of the materials that compose the different aquifer models.

4. Collect data and keep a data sheet for comparison of different porosities.

Pre-Visit Orientation - - To be completed by the instructor:

Review the hydrologic cycle with your students, placing emphasis on the infiltration and percolation of water into and through the ground. Use diagrams and information from textbooks, resource agency, or the Overview of Ground Water section.

Read the Overview of Ground Water section. Present the information in the Overview section to your students prior to the visit by the WRP. Acquaint students with the following terms described in the Overview section: hydrologic cycle, ground water, surface water, aquifer, porosity, infiltration, percolation, and permeability.

Divide the students into groups as discussed under the Instructor Responsibilities on page I-2.

Materials - - For hands-on activity:

The following list of materials is required for completion of this activity. The WRP can provide materials that are not available to you.

1. One $100-\mathrm{mL}$ (3.4-oz) graduated cylinder for each group.

2. Two 266-mL (9-oz) clear plastic cups for each group.

3. One resealable plastic sandwich bag filled with $9 \mathrm{oz}$ of dry, pea-size gravel for each group.

4. One resealable plastic sandwich bag filled with $9 \mathrm{oz}$ of a dry sand and pea-size gravel mixture for each group.

5. 3.8 liters (1 gallon) of water. 
6. One copy of the porosity data sheet for each group.

7. Five slides chosen by the WRP displaying work being done on a ground-water project or other waterresources-related project for Careers in Water Resources part of lesson plan (optional).

8. Slide projector (optional).

NOTE: This activity has been developed for small groups of students. Number of groups is limited to 10 or less. If this activity is to be conducted with more than one class in succession, replace the wet materials with dry materials for each group.

Follow-up Discussion - -To be completed by the instructor:

Review the concept of porosity discussed by the visiting WRP utilizing the same setup (as a demonstration). You may want to try some of the additional ground water activities available from the WRP or obtain additional educational materials from the selected references. 


\section{LESSON PLAN SUMMARY}

\section{Topic: Permeability}

\section{Summary/Synopsis:}

Ground water is stored in the spaces or pores between sand grains and individual pieces of gravel or in pores and/or fractures in rocks below the land surface. Water must be able to flow through these pore spaces to be available for use. The ability of rock materials to transmit water is termed permeability. Different materials have different permeabilities. The greater the permeability of an aquifer, the greater the volume of water that can be obtained from the aquifer over a given period of time.

Objectives - - The students will:

1. Discuss the uses of ground water in their community.

2. Measure the rate of water flow through different materials (sand vs. gravel).

3. Collect and record data on a data sheet. Use the data for comparison of the permeabilities of sand and gravel.

4. Learn that different materials have different permeabilities.

Pre-Visit Orientation - - To be completed by the instructor:

Review the hydrologic cycle with your students, placing emphasis on the infiltration and percolation of water into the ground. Use diagrams and information from textbooks, resource agencies, or the Overview of Ground Water section.

Read the Overview of Ground Water section. Present the information in the Overview section to your students prior to the visit by the WRP. Acquaint students with the following terms described in the Overview section: hydrologic cycle, ground water, surface water, aquifer, porosity, infiltration, percolation, and permeability.

Divide the students into groups as discussed under the Instructor's Responsibilities on page I-2.

Materials - - For hands-on activity:

The following list of materials is required for completion of this activity. The WRP can provide materials that are not available to you.

1. One cut-off spout from 2-liter soft drink containers or one 15-cm (6") funnel for each group.

2. One clear container for each group, deep enough to support the funnel and allow $100 \mathrm{~mL}$ (3.4 oz) of water to be captured without restricting the flow of water out of the funnel. The bottom part of the 2-liter soft drink container is recommended.

3. One resealable plastic sandwich bag containing enough dry pea-size gravel to fill the soft drink container spout or funnel approximately $1 / 3$ full for each group.

4. One resealable plastic sandwich bag containing enough dry sand to fill the soft drink container spout or funnel approximately $1 / 3$ full for each group.

5. One 100-mL (3.4-oz) graduated cylinder for each group.

6. Two small pieces of aluminum window screen, approximately 3 inches in diameter for each group.

7. Clock or watch with second hand. 
8. One copy of the Permeability Data Sheet for each group.

9. 5 liters (1.3 gallons) of water.

10. Five slides chosen by the WRP displaying work being done on a ground-water project or other waterresources-related project for Careers in Water Resources portion of lesson plan (optional).

11. Slide projector (optional).

NOTE: This activity can be done as a demonstration. If done as a demonstration, set up two models so that the experiment can be done at the same time. Solicit student volunteers to pour the water into the funnels and to keep time. Repeat the experiment three times, using dry materials and different student assistants for each repetition. Average and discuss the results of the three repetitions.

Follow-up Discussion - - To be completed by the instructor:

Review the concept of permeability discussed by the visiting WRP. You may want to try some of the additional ground-water activities available from the WRP or obtain additional educational materials from the selected references. 


\section{Appendix}

A. Specifications and Ordering Information for Plastic Box Ground-Water Models.

B. Follow-up Ground-Water Activities.

Build Your Own Ground-Water Model............................................................................................................. B-2

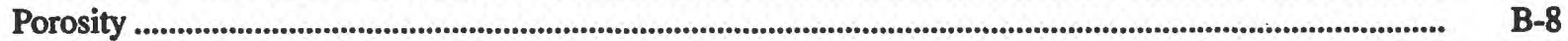

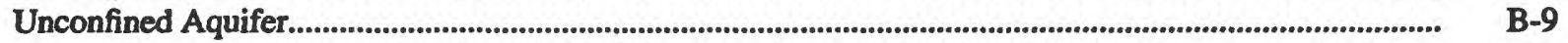

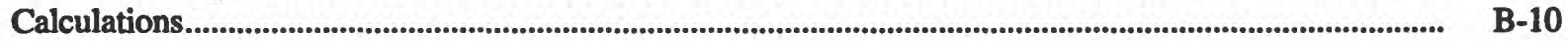

C. Selected References................................................................................................................................................... C

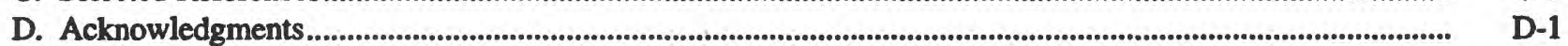

\section{FIGURES}

\section{Water Resources Professional Section}

1-18. Diagrams showing:

WRP-1. 12" x 6" x 2" Plastic Box Ground-Water Model........................................................................................... W-10

WRP-2. Aquifer Lesson Plan Activity Setup................................................................................................................ W-11

WRP-3. Ice Breaker Demonstration Setup....................................................................................................................... W-14

WRP-4. Porosity Lesson Plan Activity Setup ..................................................................................................... W-15

WRP-5. Creating a Spout and Container from a 2-L Soft Drink Container ............................................................ W-.2C

WRP-6. Permeability Lesson Plan Activity Setup............................................................................................... W-21

WRP-7. Ice Breaker Demonstration Setup............................................................................................................ W-21

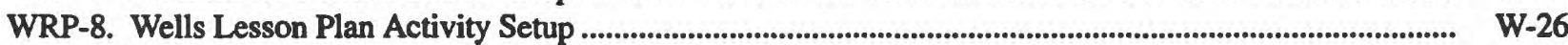

WRP-9. Ice Breaker Demonstration Setup................................................................................................................. W-27

WRP-10. Calculation Lesson Plan Activity Setup.................................................................................................. W-31

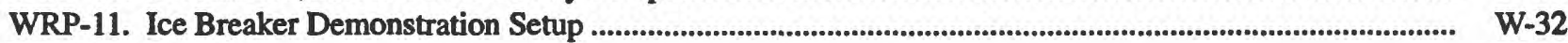

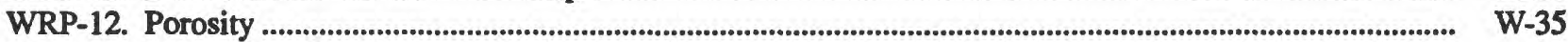

WRP-13. Unconfined Aquifer.......................................................................................................................... W-36

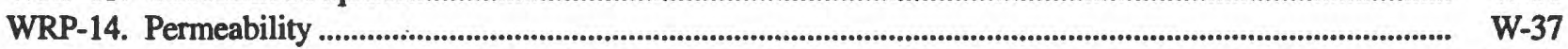

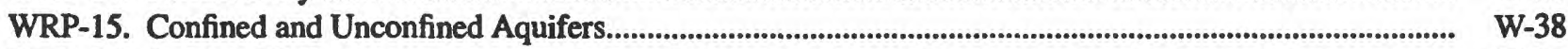

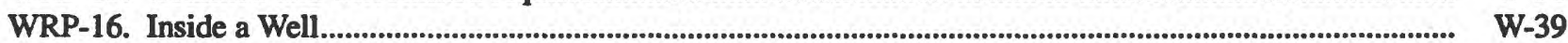

WRP-17. Hydrologic Cycle - Student Sheet.............................................................................................................. W-41

WRP-18. Hydrologic Cycle - Instructor Key Sheet........................................................................................................ W-42

\section{Instructor Section}

1-7. Diagrams showing:

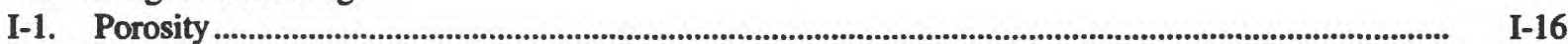

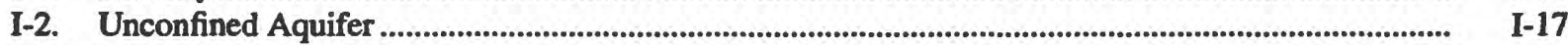

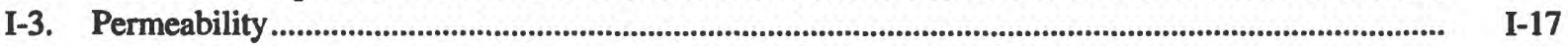

I-4. Confined and Unconfined Aquifers ..................................................................................... I-18

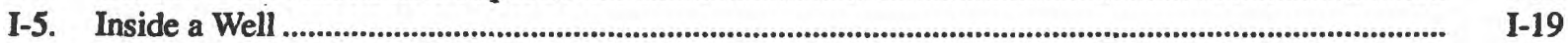

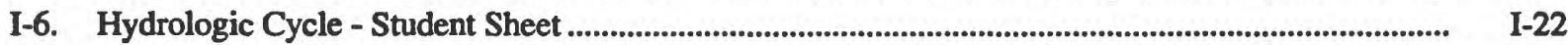

I-7. Hydrologic Cycle - Instructor Key Sheet ......................................................................... I-23

\section{Appendix}

1-8. Diagrams showing:

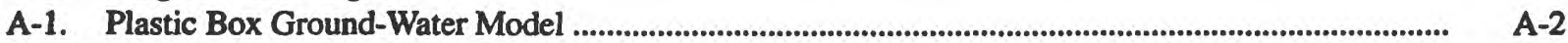

B-1. Basic Ground-Water Model .......................................................................................................... B-3

B-2. Fertilizer/Pesticide Ground-Water Model............................................................................................... B-3

B-3. Landfill/Abandoned Waste-Site Ground-Water Model ....................................................................... B-4

B-4. Leaky Underground Storage Tank Ground-Water Model ....................................................................... B-. B-4

B-5. Abandoned Well Ground-Water Model ............................................................................................. B-5

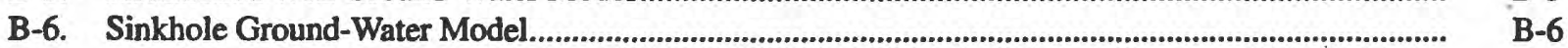

B-7. Lake Ground-Water Model ................................................................................................................. B 


\section{LESSON PLAN SUMMARY}

\section{Topic: Wells}

\section{Summary/Synopsis:}

Wells are pits, holes, or shafts sunk or driven into the Earth to tap an underground supply of water. People use this water in their homes, schools, businesses, and for agricultural purposes. Ground water is an essential natural resource that needs to be protected. We need to understand how water is removed from aquifers and the results of removing too much water from an aquifer.

Objectives - - The students will:

1. Discuss the uses of ground water in their communities.

2. Create an aquifer model and place a well in the model.

3. Measure and record the depth to water in a model well.

Pre-Visit Orientation - - To be completed by the instructor:

Review the hydrologic cycle with your students, placing emphasis on the infiltration and percolation of water into the ground. Use diagrams and information from textbooks, resource agency, or the Overview of Ground Water section.

Read the Overview of Ground Water section. Present the information in the Overview section to your students prior to the visit by the WRP. Acquaint students with the following terms described in the Overview section: hydrologic cycle, ground water, surface water, aquifer, porosity, infiltration, percolation, and permeability.

Divide the students into groups as discussed under the Instructor's Responsibilities on page I-2.

Materials - - For hands-on activity:

The following list of materials is required for completion of this activity. The WRP can provide materials that are not available to you.

1. One clear, plastic 266-mL (9-oz) cup for each group.

2. One piece of fine wire window screen for each group, approximately $3^{\prime \prime} \times 3$ ". This wire screen will be rolled around a pencil several times to make a cylinder.

3. One 7.6-cm (3") length of wire for each group.

4. One plastic pump for each group.

5. One $100-\mathrm{mL}$ graduated cylinder for each group.

6. Three cardboard strips $1 / 4$ " wide by 5 " long. These cardboard strips must be able to fit into the rolled wire screen. Cut cardboard strips from the cardboard located on the back of a notebook pad.

7. One resealable plastic bag filled with enough dry, pea-size gravel to fill the model cup approximately $3 / 4$ full for each group.

8. One ruler with metric units for each group.

9. Copy of Well Data Sheet for each group.

10. 3.8 liters ( 1 gallon) of water. 
11. Food coloring.

12. Five slides chosen by the WRP displaying work being done on a ground-water project or other waterresources-related project for Careers in Water Resources part of lesson plan (optional).

13. Slide projector (optional).

NOTE: It is not recommended that this activity be done as a demonstration. Be sure there are sufficient materials for each group.

Follow-up Discussion - - To be completed by the instructor:

Review the concept of permeability discussed by the visiting WRP. You may want to try some of the additional ground-water activities available from the WRP or obtain additional educational materials from the selected references. 


\section{LESSON PLAN SUMMARY}

\section{Topic: Calculations}

\section{Summary/Synopsis:}

Ground water is an essential source of water that people use at home, school, and work. The amount of ground water that is stored in layers of sand, gravel, and rock can be determined mathematically. Using a simple aquifer model constructed by the students, the volume of spaces between particles of pea-size gravel can be measured. By understanding these concepts, it is possible to determine the quantity of water in storage in a model aquifer. Similar measurements are made by hydrologists to determine the quantity of ground water in an aquifer.

Objectives - - The students will:

1. Practice their mathematical skills:

a. Measure the length, width, and height an aquifer model.

b. Calculate the volume of the aquifer model from these measurements.

c. Calculate the volume of water that the model aquifer can hold.

2. Students will study the following aspects of ground-water systems and quantify their observations:

a. Saturated-zone dimensions;

b. Depth to water table;

c. Aquifer dimensions;

d. Porosity.

Pre-Visit Orientation - - To be completed by the instructor:

Review the hydrologic cycle with your students, placing emphasis on the infiltration and percolation of water into the ground. Use diagrams and information from textbooks, resource agency, or the Overview of Ground Water section.

Read the Overview of Ground Water section. Present the information in the Overview section to your students prior to the visit by the WRP. Acquaint students with the following terms described in the Overview section: hydrologic cycle, ground water, surface water, aquifer, porosity, infiltration, percolation, and permeability.

Divide the students into groups as discussed under the Instructor's Responsibilities on page I-2.

Materials - - For hands-on activity:

The following list of materials is required for completion of this activity. The WRP can provide materials that are not available to you.

1. One 2-liter soft drink container with spout cut off approximately $12.7 \mathrm{~cm}\left(5^{\prime \prime}\right)$ below the spout or a clear, square baking pan approximately $12.7\left(5^{\prime \prime}\right)$ deep for each group

2. Sufficient dry pea-size gravel to fill all the containers $3 / 4$ full. This will be approximately $20 \mathrm{lbs}$.

3. One 100-mL graduated cylinder for each group.

4. One ruler with metric units for each group.

5. Pencils and paper. 
6. 7.6 liters ( 2 gallons) of water.

7. Sponges for cleanup.

8. Five slides chosen by the WRP displaying work being done on a ground-water project or other waterresources-related project for Careers in Water Resources part of lesson plan (optional).

9. Slide projector (optional).

NOTE: This activity can be done as a demonstration or a group activity. If done as a group activity, be sure there are sufficient materials for each group in the class.

Follow-up Discussion - -To be completed by the instructor:

Review the concept of porosity discussed by the visiting WRP. You may want to try some of the additional ground-water activities available from the WRP or obtain additional educational materials from the selected references. 


\section{OVERVIEW OF GROUND WATER}

\section{Saturated and Unsaturated Zones}

Precipitation falls to Earth, remains on the surface, or infiltrates into the soil. Water that remains on the Earth's surface is called surface water. Water that infiltrates beneath the land surface becomes ground water. Ground water is stored and flows in the pore spaces between rock materials and in solution openings and fractures in some types of rocks. The ability of rock material to store water is known as porosity. Porosity is measured as a ratio of openings in the rock material to the total volume of rock material and is usually described as a percentage. (See Figure I-1.)

Fresh water is critical to many living organisms, yet only 3 percent of the water on Earth is fresh water. There are two main sources of fresh water: surface water and ground water. Surface water flows over the land surface in rivers, streams, and lakes. Ground water exists beneath the surface of the Earth, making it a hidden resource. Ground water makes up about 95 percent of the fresh-water resources in the United States.

Ground water is water beneath the Earth's land surface, filling pores (open spaces) and fractures in geologic formations. Ground water can be collected by pumping from wells or may be found flowing naturally to the surface at springs. It can sustain the flow of rivers and streams during dry periods or be a source of water flowing into lakes, ponds, or wetlands. Nationally, about $40 \%$ of municipal, domestic, and agricultural water is supplied by ground water. The following discussion is a refresher on the basic terminology and physical processes associated with ground water.

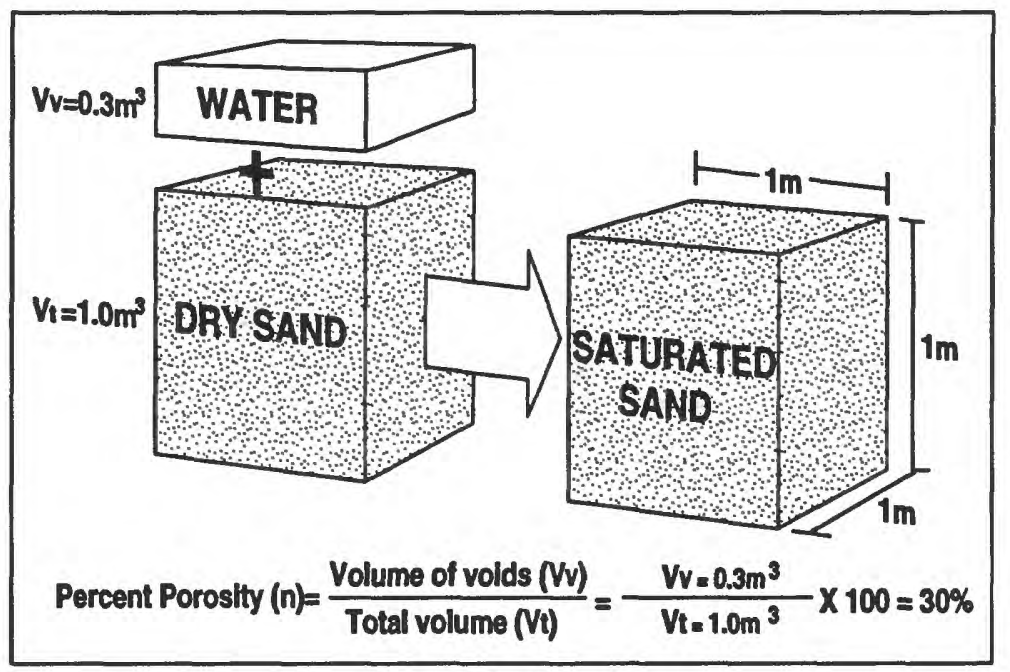

Figure 1-1. Porosity.

Porosity of loosely arranged (unconsolidated) rock materials such as sand and gravel depends on the range in particle size (sorting) and on the shape of the rock particles. In nature, layers of loosely arranged rock materials of fairly uniform size (such as sand) tend to have a greater percent porosity than layers of loosely arranged rock materials containing materials of different sizes. This is because the smaller rock materials tend to settle in the pore spaces between larger rock materials, decreasing the amount of open space (or porosity). In other words, if the loosely arranged rock materials that make up underground rock layers are all about the same size (a well-sorted material), the pore spaces between the materials account for a larger percentage of the whole volume. In addition to particle-size sorting, the porosity of sediments is affected by the shape of the particles. Particles with a spherical shape will pack more tightly than particles with angular edges, resulting in a greater porosity for angular-shaped particles. 
Ground water occurs below the land surface in two different zones. The unsaturated zone is immediately below the land surface and contains water and air. The unsaturated zone is almost always underlain by a zone in which all the pores and fractures are full of water, the saturated zone. The top of the saturated zone is called the water table (see Figure I-2). The water table may be just below the land surface or hundreds of meters below the land surface.

If underground rock materials are capable of storing and transmitting water in useful amounts, the rock materials are called an aquifer. Underground rock materials such as clay or unfractured crystalline rock that restrict the flow of water are not aquifers but are confining materials.

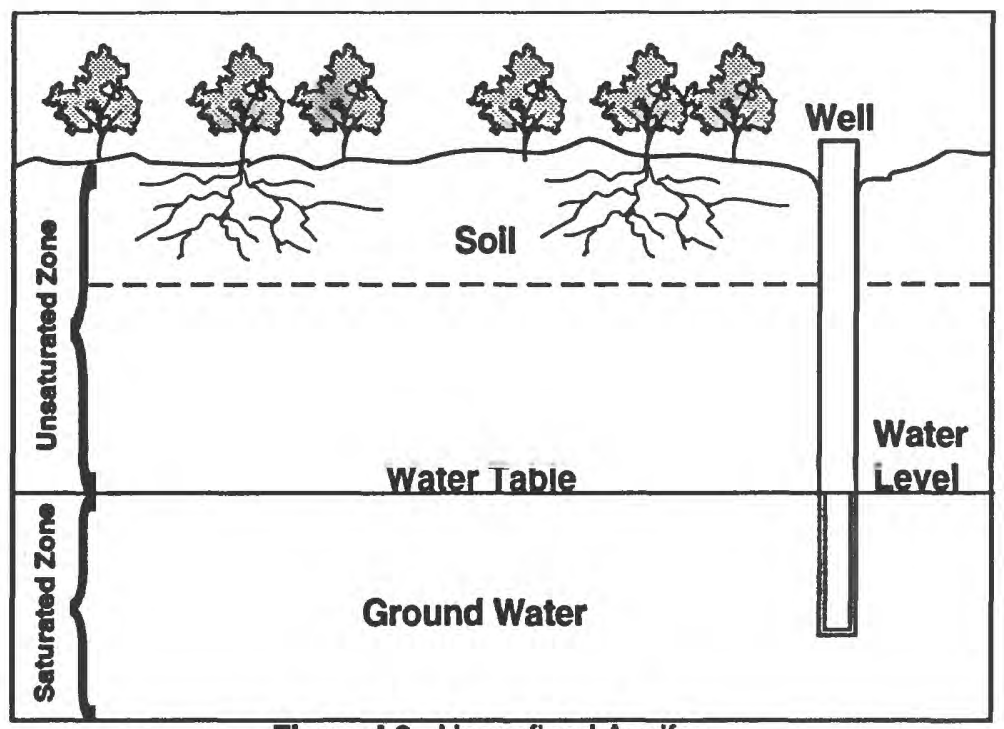

Figure 1-2. Unconfined Aquifer.

If water is to move through underground rock materials, pore spaces or fractures must be connected to one another. If the pore spaces or fractures are not connected, the rock material will not yield water and will act as a confining material and not an aquifer. If rock materials have good connections between pore spaces or fractures and water can move freely through them, we say that the rock is permeable. Permeability refers to the capability of a material to transmit water (see Figure I-3).

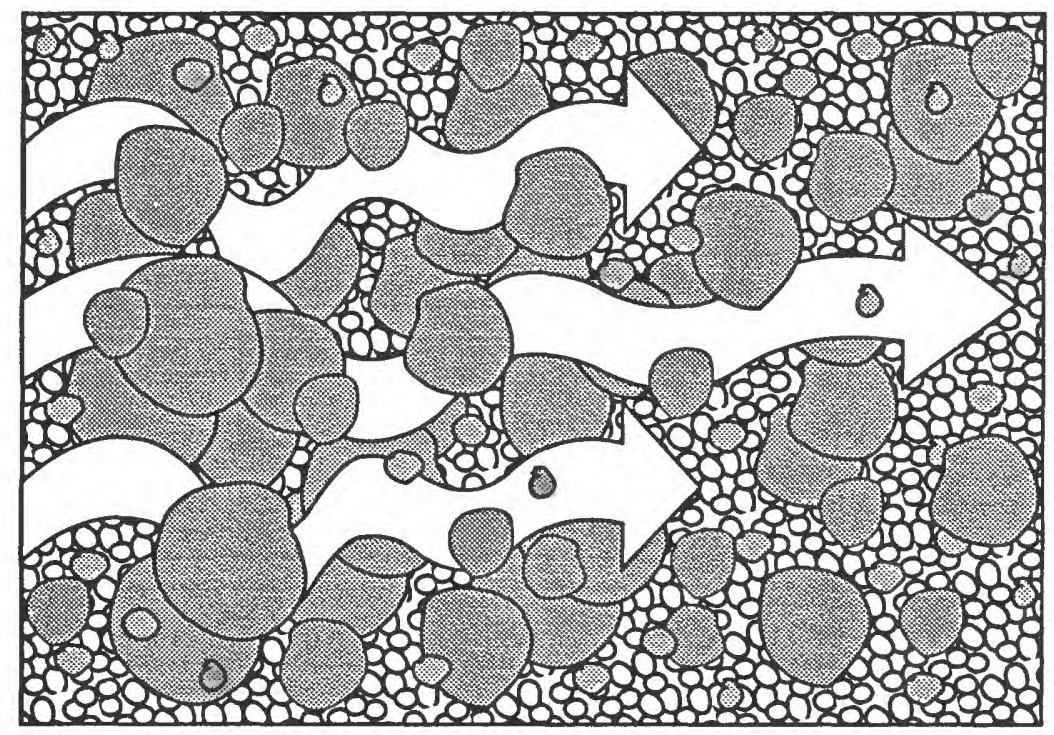

Figure 1-3. Permeability. 
Ground water occurs in the saturated zone under two different conditions. One condition exists where water completely fills an aquifer and the aquifer is overlain by a confining bed. Such aquifers are referred to as confined or artesian aquifers.

Wells completed in a confined aquifer are referred to as artesian wells. The water level in an artesian well is located at a height above the top of the aquifer, indicating that the water in the confined aquifer is under pressure (see Figure I-4). The water level is termed the potentiometric surface. In some instances the height of the water level in an artesian well may rise above land surface. In this instance the well is a flowing artesian well.

The second condition exists where the saturated zone only partly fills an aquifer. As the water continues to move through the saturated zone, the water table is free to rise and fall. Water in such aquifers is said to be unconfined, and hence the aquifer is called an unconfined or water-table aquifer. Water levels of wells placed into a water-table aquifer indicate the position of the water table in the aquifer (see Figure I-4).

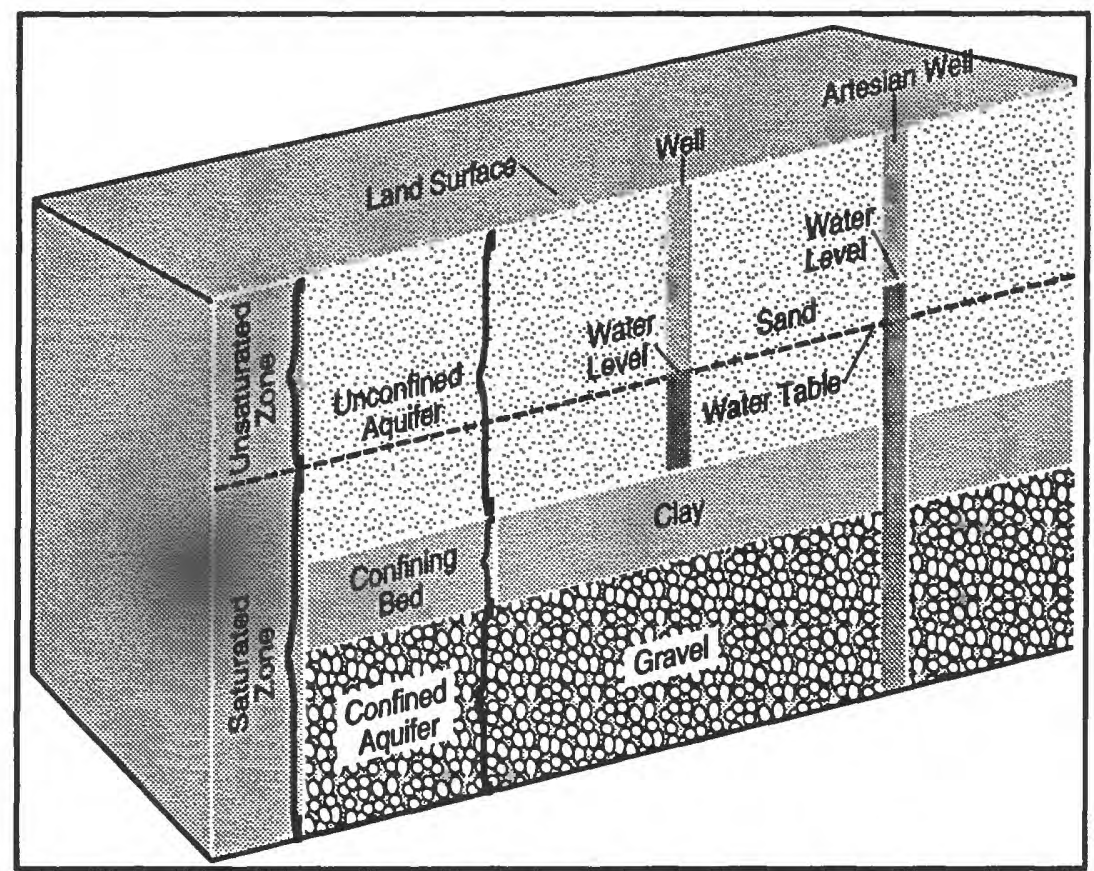

Figure I-4. Confined and Unconfined Aquifers.

The volume of water that an aquifer can hold depends upon the volume of the underground rock materials and the size and amount of pores and fractures that can be filled with water. An aquifer may be only one meter or thousands of meters thick. It may be less than a square kilometer in area or hundreds of thousands of square kilometers in area. For example, the High Plains Aquifer underlies about 450,000 square kilometers in parts of eight States -- Colorado, Kansas, Nebraska, New Mexico, Oklahoma, South Dakota, Texas, and Wyoming.

Aquifers receive water from precipitation that infiltrates down through the unsaturated zone and directly from some surface-water bodies such as lakes, streams, or rivers. Areas where infiltration to aquifers occurs are commonly referred to as recharge areas. 
Where the land surface intersects the water table or potentiometric surface, water stored in the aquifer can flow at the land surface as a spring or seep. Most surface-water bodies such as rivers, ponds, and wetlands obtain most or part of their water from ground water. The water level of some ponds and wetlands can be an extension of the local water table or potentiometric surface. Locations where ground water flows or is discharged to the land surface or to surface-water bodies are referred to as discharge areas.

Ground water also can be brought to the surface by pumping from a well or can naturally flow out of the ground where the water table comes in contact with the land surface (for example a spring). A well is an opening that was drilled or dug into the aquifer (see Figure I-5). Water from the aquifer will flow into this opening to replace water removed from the borehole by a pump. Where materials that comprise the aquifer would fall into the well and tend to fill the well opening, the aquifer materials need to be supported with a pipe or "well casing." Perforations in the well casing are placed below the water table or potentiometric surface, allowing water to flow into the well.

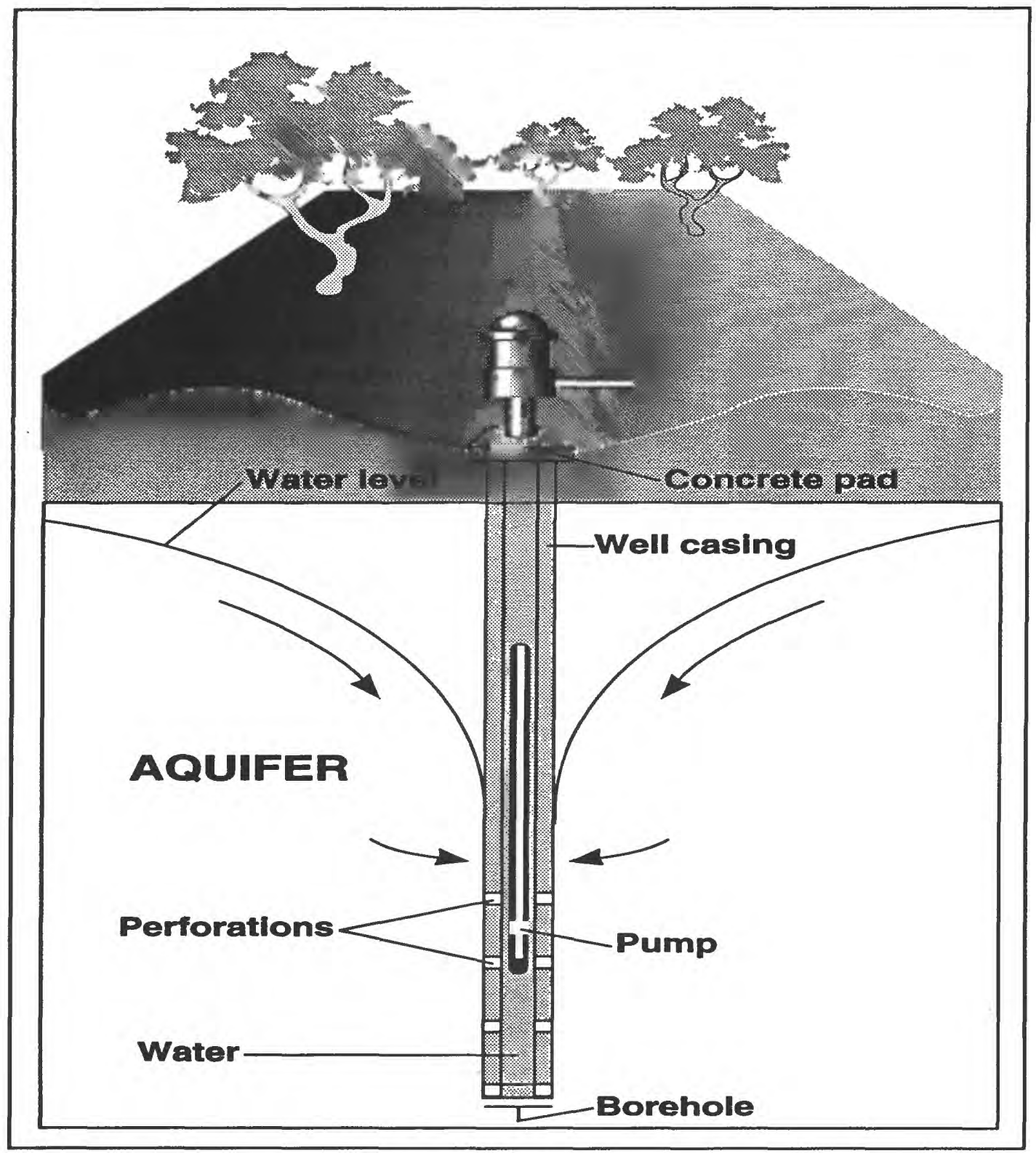

Figure 1-5. Inside a Well. 


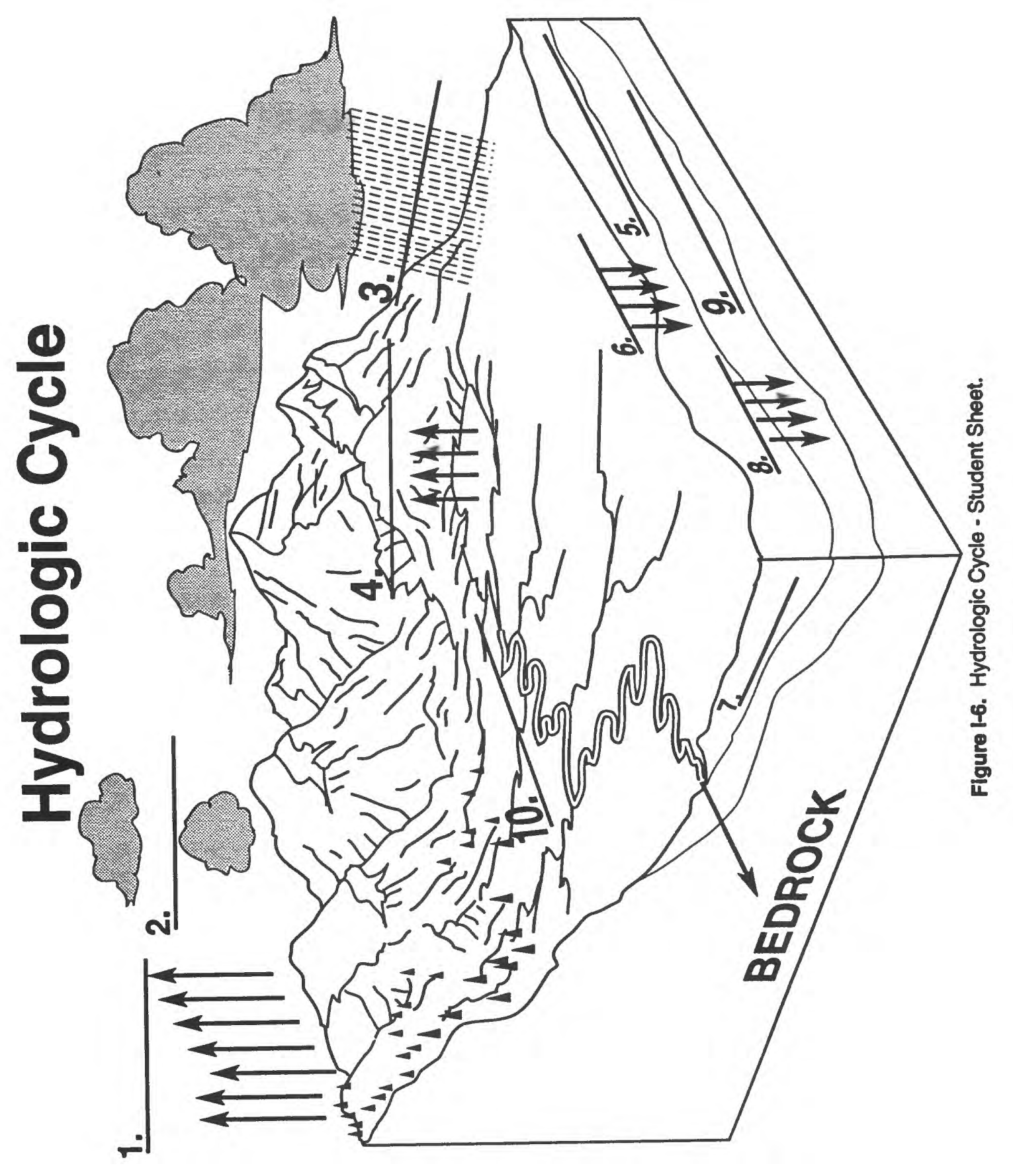




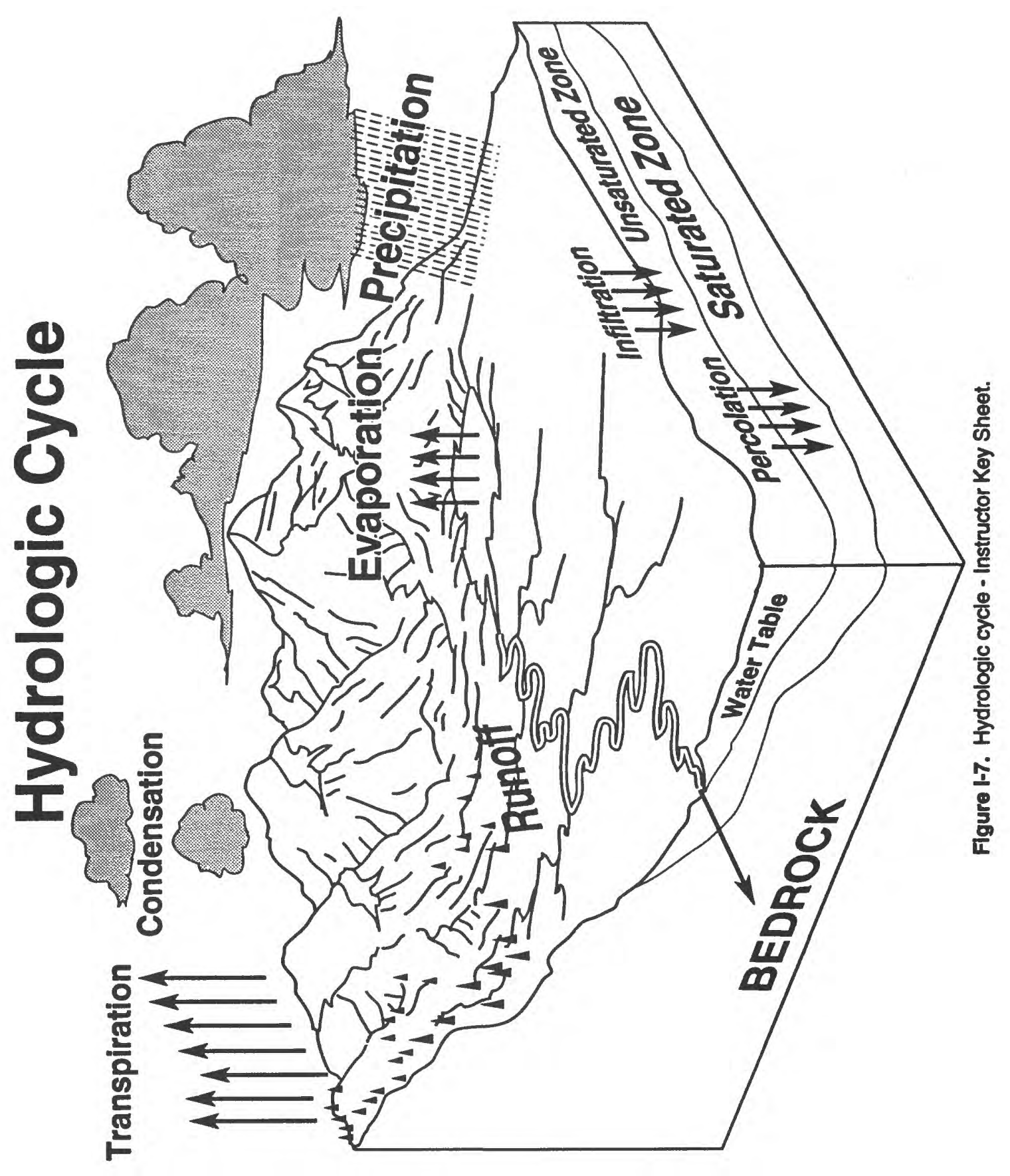




\title{
Water Resources Professional's Outreach Notebook Ground Water Grade Level 6-8
}

\author{
By Stephen J. Vandas
}

\begin{abstract}
This publication was developed for educational outreach. It provides a mechanism whereby an individual employed in a scientific field associated with water resources assists an instructor (school teacher, Girl or Boy Scout leader, 4-H counselor, etc.) in presenting information on selected ground-water topics. The educational materials require an instructor and water resources professional to work together. The publication contains five lesson plans and is divided into two sections, one for an instructor and one for the water resources professional.
\end{abstract}




\section{GLOSSARY}

The following terms have been defined in terminology understandable to students in grades 6-8. Scientific terms can be a foreign language to students, hindering the most important part of science educationunderstanding scientific principles and concepts. When using scientific terms, it is important to use proper definitions of terms that are understandable to the audience ( $6-8$ grade students). The following definitions are the result of combined work of water resources professionals and practicing teachers in grades 6-8 to ensure understanding by students in grades 6-8. It is recommended that both the water resources professional and instructor use these definitions when conducting the lessons.

AQUIFER: An underground layer of porous sand, gravel or fractured rock capable of storing and supplying water to a well or spring.

ARTESIAN AQUIFER (same as confined aquifer): An aquifer completely filled with water overlain by a confining layer. Because water is under greater than atmospheric pressure at the top of the aquifer, water levels in wells located in the aquifer rise above the top of the aquifer.

ARTESIAN WELL: A well drilled into an artesian aquifer. Water in the well rises above the top of the aquifer.

BENEFICIAL USE OF WATER: The use of water for purposes such as domestic, livestock, irrigation, recreation, fish and wildlife, fire protection, power, industrial use, etc.

CONFINING BED (Same as confining layer): A layer of rock material that restricts the flow of water.

CONFINED AQUIFER: See artesian aquifer.

CONSERVATION: To protect from loss and waste.

CONSUMPTIVE USE: A use of water where a part is used up and no longer immediately available for use or reuse.

CUBIC FOOT PER SECOND (cfs) $\left(\mathrm{ft}^{3} / \mathrm{s}\right.$ ): A cubic foot of water moving 1 foot in 1 second. A term used in the measurement of the volume of streamflow.

DRAWDOWN: The lowering of the water level in an aquifer caused by the discharge of water.

EVAPORATION: The process by which liquid or solid water becomes vapor.

EVAPOTRANSPIRATION: Loss of water from land areas by evaporation from soil and plant surfaces, and transpiration of water by plants.

FLOW: The volume of water moving past a point during a specified time. Also known as discharge.

GROUND WATER: Water beneath the land surface.

GROUND-WATER DISCHARGE: The flow or pumping of water from an aquifer.

GROUND-WATER RECHARGE: The addition of water to an aquifer.

HYDROLOGIC CYCLE (water cycle): The continuous movement of water from the ocean to the atmosphere, to the land, and back to the ocean. The hydrologic cycle has no beginning or end.

IMPERVIOUS: Resistant to penetration by water or plant roots.

INFILTRATION: Movement of water from land surface into the soil.

PERCOLATION: The movement of water through the subsurface soil layers, usually continuing downward into the saturated zone.

PERMEABILITY: The capability of porous soil or rock for transmitting water.

POLLUTION: Contamination from human activities that restricts the uses of water.

PORE SPACE: That portion of rock or soil not occupied by solid mineral matter and that may be occupied by ground water or other liquids or gases.

POROSITY: The volume of pore spaces in a rock or layer of earth materials divided by the total volume of rock and expressed as a percent.

POTENTIOMETRIC SURFACE: A surface that represents the level to which water will rise in a well.

PRECIPITATION: Rain, snow, mist, sleet, or hail.

RAIN: Water drops that are heavy enough to fall to earth from the air.

RAINFALL: The quantity of water that falls as rain only.

RUNOFF: The portion of rainfall, melted snow, or irrigation water that flows across the land surface and eventually flows into streams, lakes, or the oceans.

SATURATED ZONE: Zone below the land surface where all pores or fractures are filled with water.

SOIL MOISTURE: Water partially filling some pores in the soil.

SPECIFIC YIELD: The volume of water that can be drained by gravity from the pores of sand, gravel, soil, or rock divided by the total volume of material and expressed as a percent. 
SURFACE WATER: Water on land surface such as oceans, streams, lakes, etc.

UNCONFINED AQUIFER: An aquifer whose upper water surface (water table) is at atmospheric pressure and is free to rise and fall.

UNSATURATED ZONE: The zone, which usually occurs immediately below the land surface, where the pores or fractures contain both water and air.

WATER CYCLE: See Hydrologic Cycle.

WATER QUALITY: A term used to describe the chemical, physical, and biological characteristics of water.

WATER TABLE: The top of the water surface in the saturated zone of an unconfined aquifer.

WELL: A pit, hole, or shaft sunk into the earth to observe or tap an underground supply of water. 



\section{APPENDIX A \\ GROUND-WATER MODELS}


Specifications and ondering information fuc plastic box ground-water models:

The 12" $\times 6^{\prime \prime} \times 2^{\prime \prime}$ plastic box is an effective tool for use in creating models of ground-water systems. These plastic boxes provide all the demonstration capabilities of larger commercial models costing hundreds of dollars each. Besides the obvious cost advantage, the $12^{\prime \prime} \times 6^{\prime \prime} \times 2^{\prime \prime}$ plastic models allow students to create their own ground- water system rather than being limited to a fixed setup that is created for demonstration purposes only.

\section{Specifications:}

Box: clear acrylic plastic $1 / 8^{\prime \prime}$ thick.

Dimensions: $12^{\prime \prime} \times 6^{\prime \prime} \times 2^{\prime \prime} \pm 1 / 8 "$.

Open at top - 2" $\times 12^{\prime \prime}$.

$1 / 2^{\prime \prime}$ hole drilled in bottom of one $2^{\prime \prime} \times 6^{\prime \prime}$ side approximately $1 "$ up from the bottom.

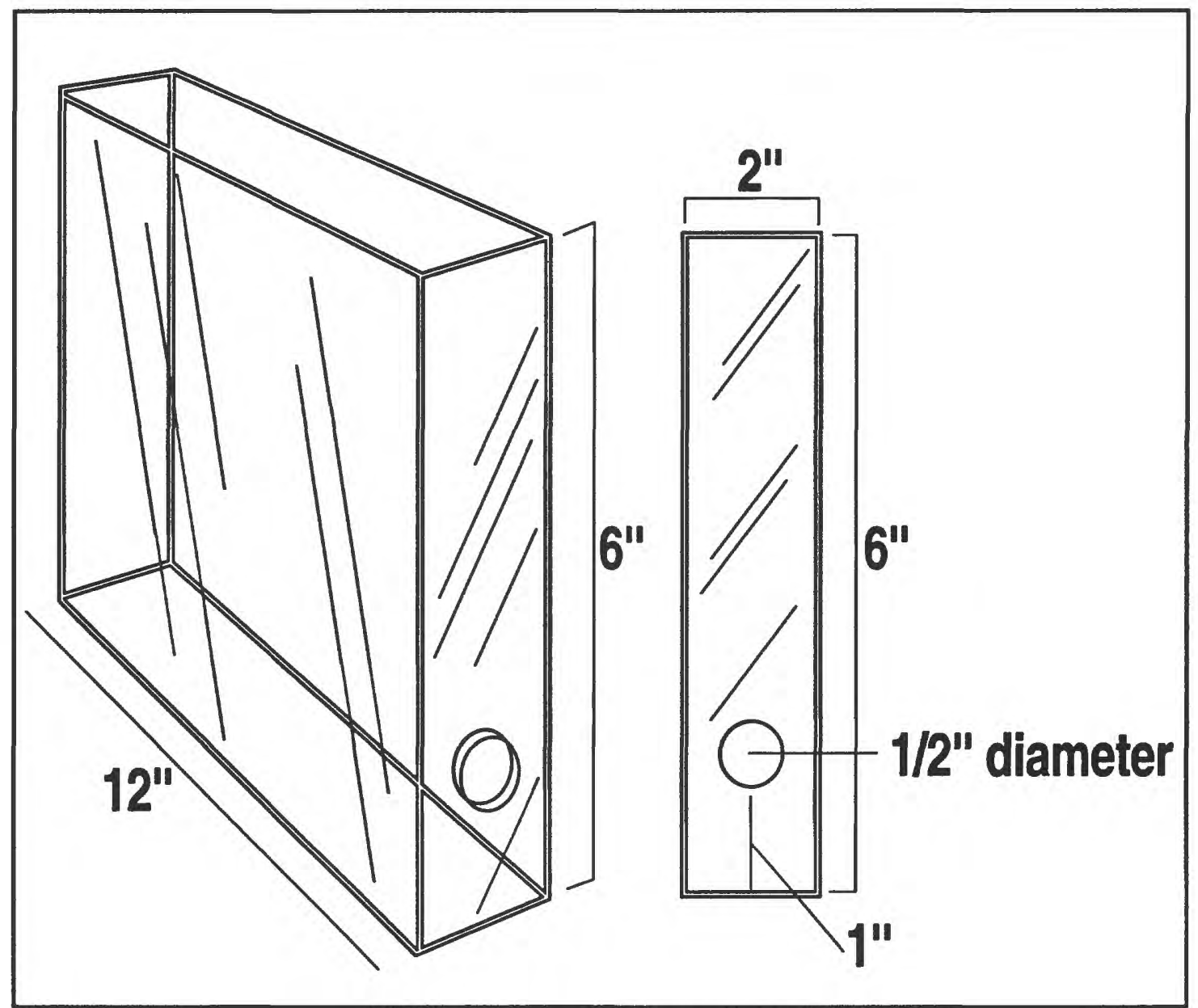

Figure A-1. Plastic Box Ground-Water Model.

One outlet for the plastic boxes for ground-water models is:

Colorado School of Mines

Office of Special Programs and Continuing Education

Denver Earth Science Project

(303) 273-3494

A local plastic molder in your town or city or a school shop class may build a plastic box according to the above specifications. Use diagram A-1 for reference when talking to plastic molders. 


\section{APPENDIX B \\ FOLLOW-UP GROUND-WATER ACTIVITIES}




\section{Activity 1}

Build Your Own Ground-Water Model

PURPOSE: To investigate the basic physical properties of a model aquifer and the adverse effects of pollutants on ground water.

\section{Materials Needed:}

1. Plastic ground water-model (12"long $\times 6$ " high $\times 2^{\prime \prime}$ wide) or a similar clear container for each group.

2. Aquarium gravel or washed pea-size gravel.

3. Plumber's putty or modeling clay.

4. One pump dispenser from soft soap or hand-lotion container for each group.

5. Two clear, plastic straws for each group.

6. Powdered-drink mix.

7. One $1.5-\mathrm{oz}$ bottle food coloring.

8. Paper towel.

9. Film canister.

10. Pop can.

11. 20-30 sugar cubes.

12. Paper cup.

13. Water container.

14. One $1 / 2$ " diameter rubber stopper.

\section{PROCEDURE:}

1. Set up model(s) as shown on the diagrams on pages B-3 through B-7. (Instructions on following pages.) NOTE: Depending upon availability of materials, this activity could be done as a demonstration or as a project for student lab groups.

2. After model(s) are set up, have students experiment with the model(s) as described under Using the Ground-Water Models, pages B-3 through B-7.

3. Each student group will present its model to the class for demonstration.

4. Each group will lead the class in a discussion on porosity and permeability, and how the ground water in their model could become contaminated or polluted.

5. The class will discuss each group presentation and possible solutions to ground-water pollution problems.

\section{SUMMARY:}

Ground water is stored in layers of sand, gravel, or rock (geologic formations) below the surface of the Earth. Through land use (agricultural, urban, industrial) humans can affect the quality and quantity of ground water. This exercise requires teams of students to build a ground-water model. The students will experiment, evaluate, and interpret their models and simulate various problem scenarios with the model. Possible preventative measures for these situations will be discussed. 


\section{Using the Ground-Water Models}

Reprinted with permission of the GREAT Program, Iowa Department of Natural Resources, Appendix A, Great Ways to Use the Ground-Water Model (GREAT - Groundwater Resources and Educational Activities for Teaching).

The following are instructions for using the ground-water model for student activities and/or teaching demonstrations. These are suggested methods. Instructors are encouraged to allow students to experiment.

\section{Basic Ground-Water Model:}

Use aquarium gravel, clear plastic straw, and clay to build the ground-water model as shown in Figure B-1. Pour water in the model. Observe, record, and discuss the results. Use the pump to show how a well pumps water from an aquifer. The water level in the clear plastic straw demonstrates an artesian system.

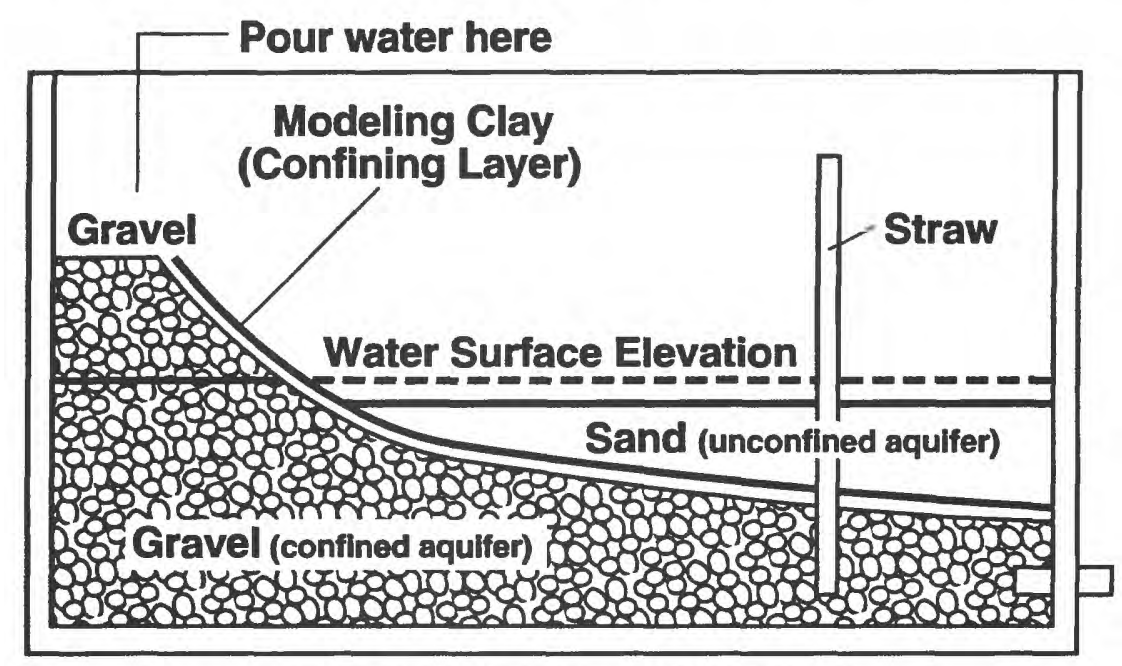

Figure B-1. Basic Ground-Water Model.

\section{Fertilizer/Pesticide Model:}

Build the ground-water model as shown in Figure B-2. Add water until the bottom one-fourth of the pump is submerged. Sprinkle powdered drink mix on the surface as shown to represent fertilizer or pesticides put on a field. Sprinkle water over the surface to simulate rain and observe, record, and discuss the results. Continue to add water until the bottom one-half of the pump is under water. Press the pump 20-30 times and catch the water removed in another container. Observe, record, and discuss the results.

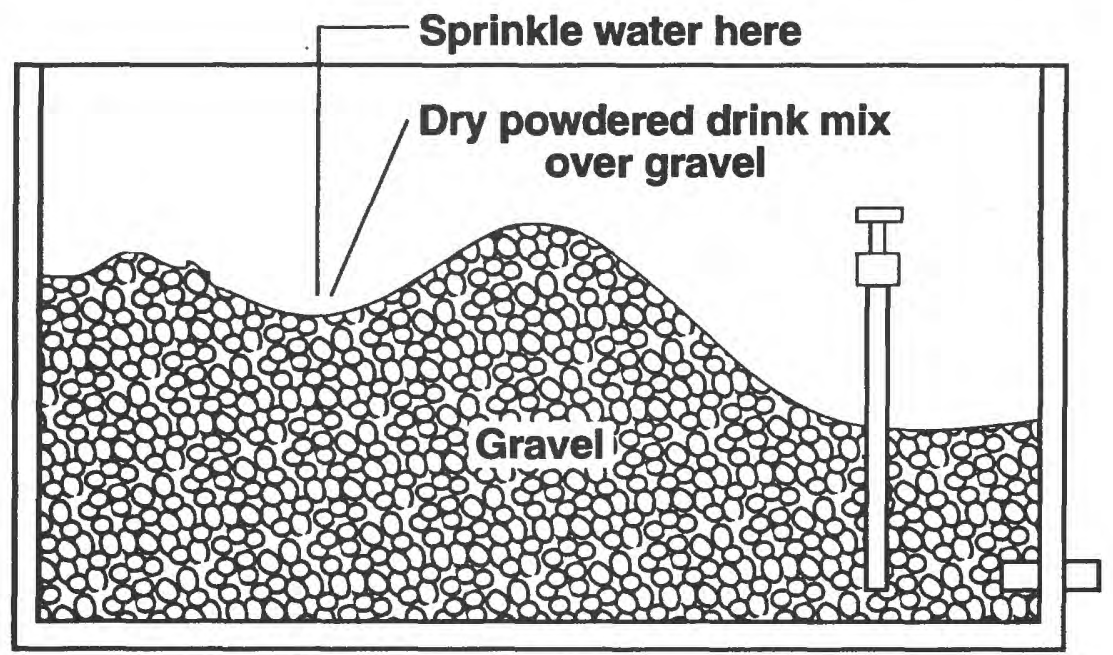

Figure B-2. Fertilizer/Pesticide Ground-Water Model. 
Landfill/Abandoned Waste-Site Model:

Build the ground-water model as shown in Figure B-3. Add water until the bottom one-fourth of the pump is submerged. Roll a paper towel into a ball and saturate it with food coloring. Place it beneath the surface as shown to represent an improperly designed, abandoned waste site or landfill. Sprinkle water on the surface and observe, record, and discuss the results. Continue to add water until the bottom one-half of the pump is under water. Press the pump 20-30 times and catch the water removed in another container. Observe, record, and discuss the results.

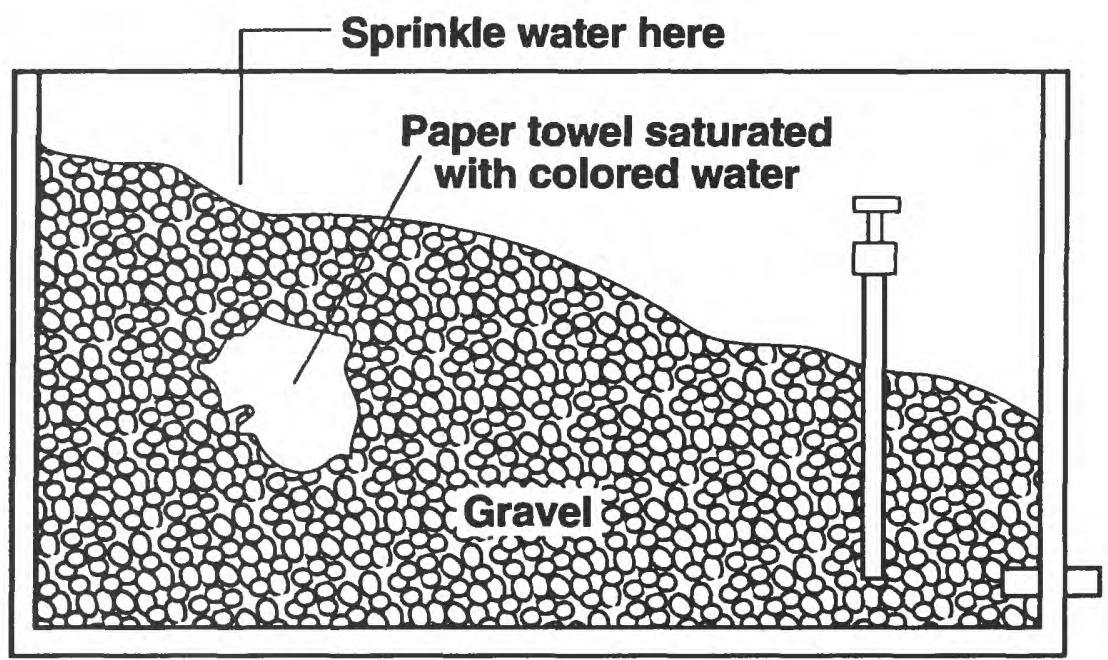

Figure B-3. Landfill/Abandoned Waste-Site Ground-Water Model.

\section{Leaky Underground Storage-Tank Model:}

Build the ground-water model as shown in Figure B-4. Add water until the bottom one-fourth of the pump is submerged. Puncture a film canister in several places with a pin and fill it with colored water. Place it beneath the surface (not along the side of the box) as shown. Sprinkle water on the surface and observe, record, and discuss the results. Continue to add water until the bottom one-half of the pump is under water. Press the pump 20-30 times and catch the water removed in another container. Observe, record, and discuss the results.

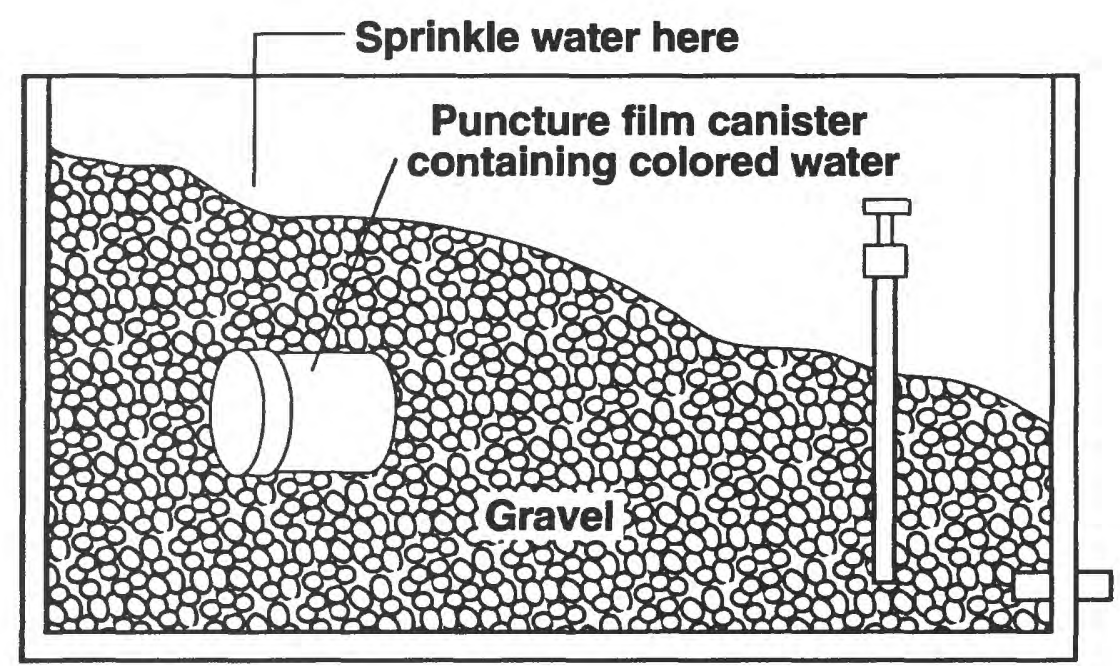

Figure B-4. Leaky Underground Storage Tank Ground-Water Model. 


\section{Abandoned Well Model:}

Build the ground-water model as shown in Figure B-5. Fill model 3/4 full with clear water, which will submerge the bottom clay layer. The straw with holes in it and with clay plugging the bottom simulates an abandoned well. Pour colored water into the abandoned well and observe, record, and discuss the results. An eyedropper or pipet may be used to add the colored water to the straw.

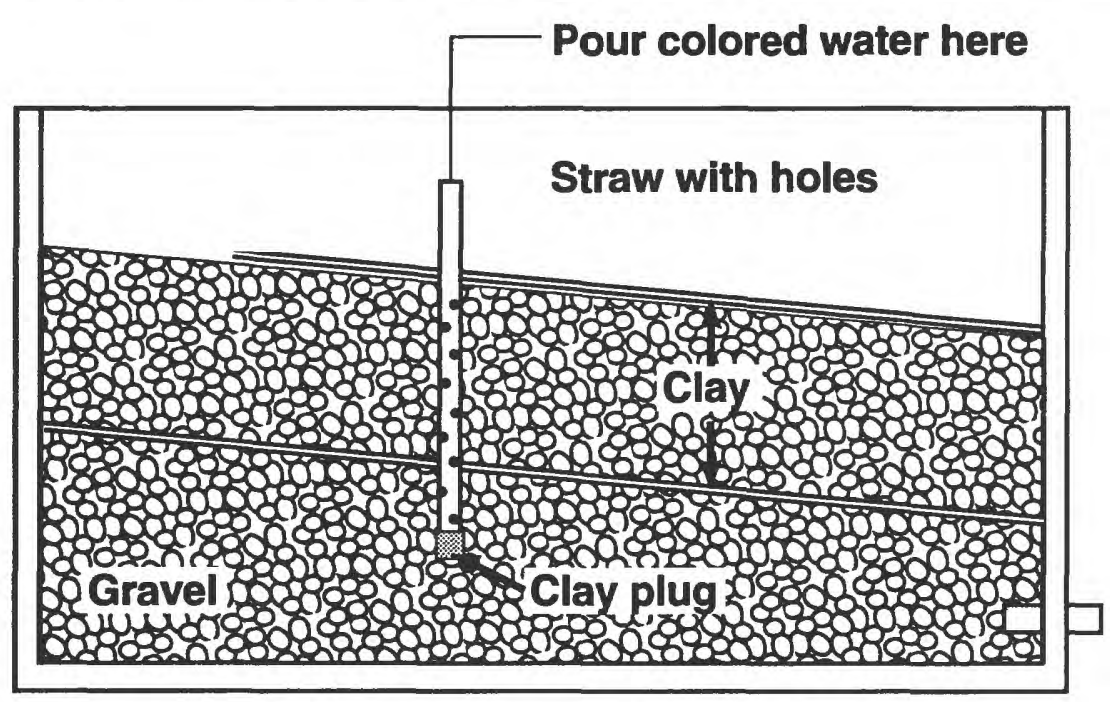

Figure B-5. Abandoned Well Ground-Water Model. 


\section{WATER RESOURCES PROFESSIONAL SECTION}




\section{Sinkhole Model:}

Build the ground-water model as shown in Figure B-6. Bury about 24-30 sugar cubes (at least 3 high, 4 wide, and 2 deep) to represent a layer of limestone that will be dissolved to form a sinkhole. Use a nonpermanent marker to draw a line showing the gravel surface. Set up a pop can with holes in the bottom to slowly sprinkle hot water onto the surface over the sugar cubes. After the sinkhole has formed, pour colored water into it to simulate contaminated water entering the aquifer through the sinkhole. Observe, record, and discuss the results. Press the pump 20-30 times and catch the water removed in another container. Observe, record and discuss the results.

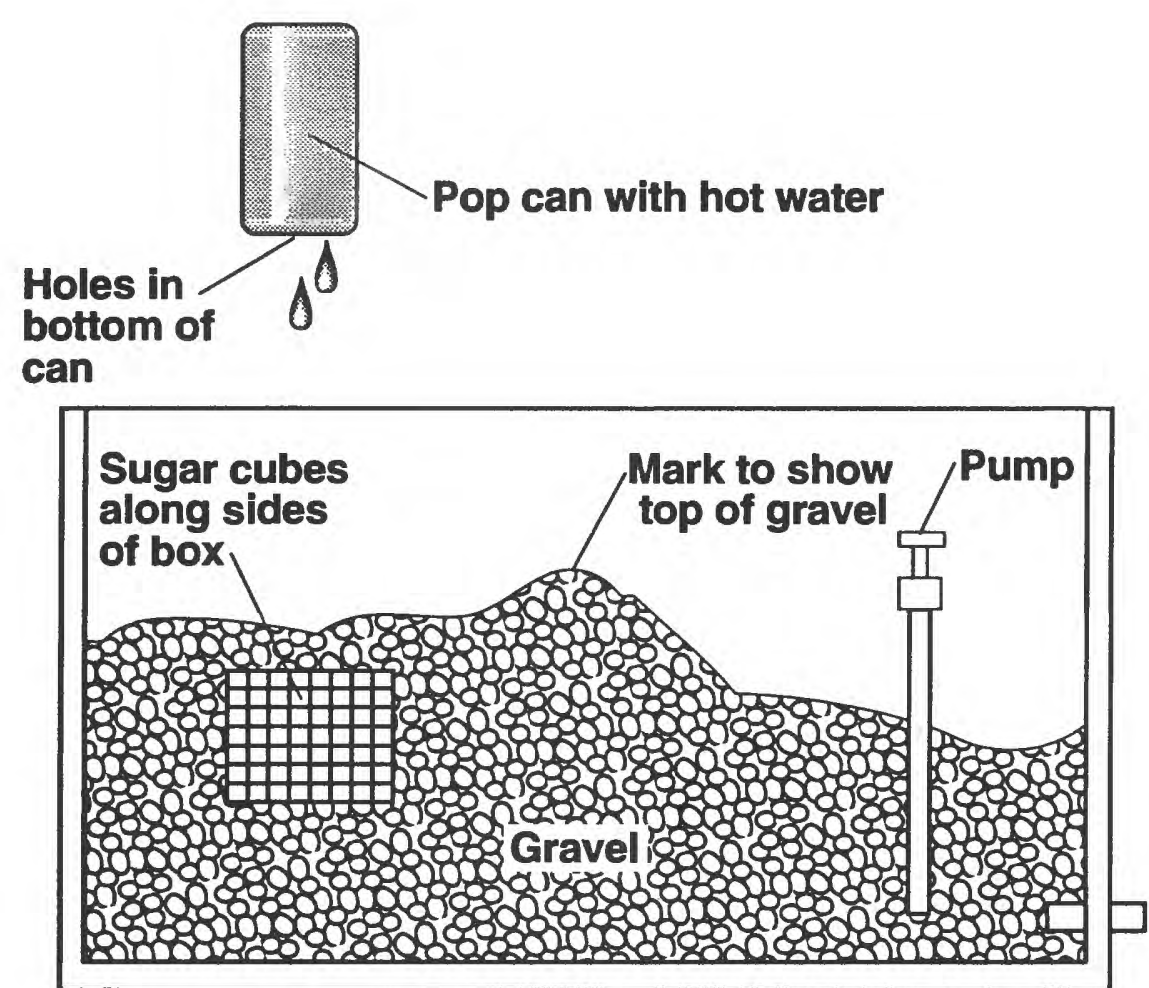

Figure B-6. Sinkhole Ground-Water Model. 


\section{Lake Model:}

Build the ground-water model as shown in Figure B-7. Poke pin holes in the bottom part of the paper cup. Pour water onto the gravel until water in the gravel is just below the bottom of the cup. Fill the lake (paper cup) with colored water. Pump, observe, record, and discuss the results.

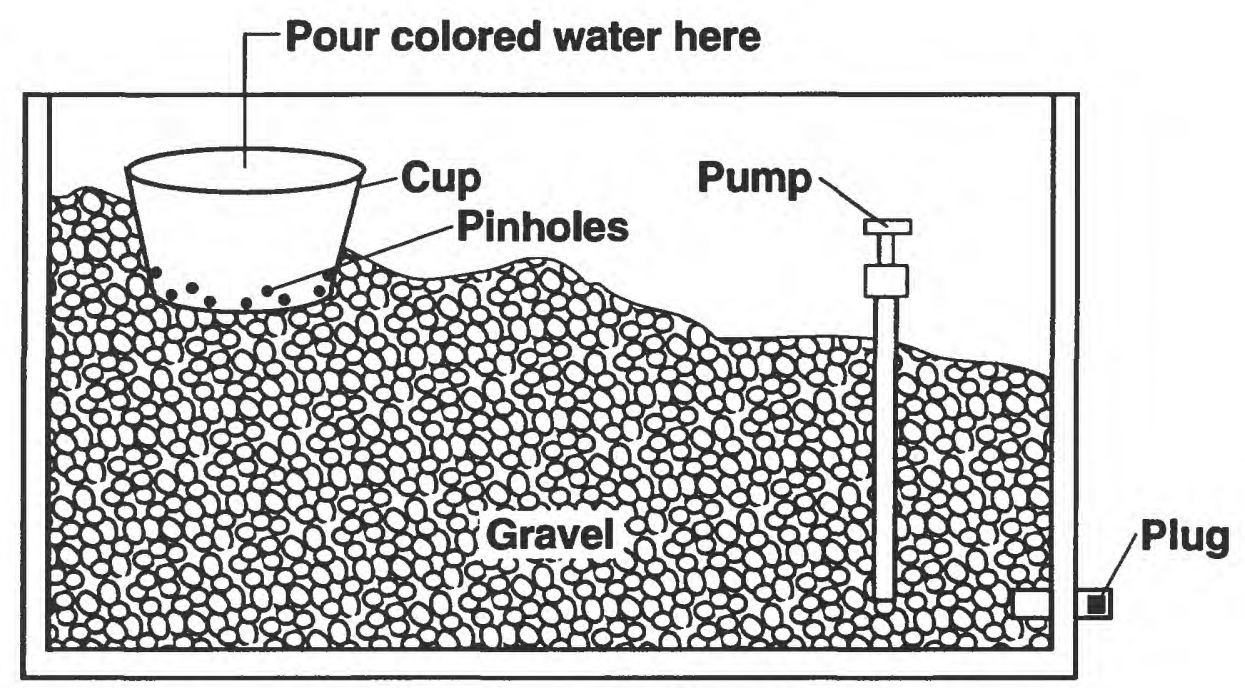

Flgure B-7. Lake Ground-Water Model. 


\section{Activity 2}

Porosity

PURPOSE: To demonstrate that different sedimentary materials have different porosities.

\section{Materials Needed:}

1. Plastic box ground-water model or large, clear bowl.

2. Equal volumes of pea-size gravel, dry sand, and sand/gravel mixture, enough to fill the plastic box ground-water model or bowl once with each material.

3. 100-mL (3.4-oz.) graduated cylinder.

4. Sufficient water to fill models of all groups.

\section{PROCEDURE:}

1. Fill plastic box ground-water model or bowl with pea-size gravel.

2. Ask the students to estimate the amount of water (in $\mathrm{mL}$ ) that should be added to bring the water level in the container to the top of the material.

3. Measure water using the graduated cylinder, keeping track of the volume as you pour the water into the container. Stop pouring when the water level has reached the top of the material in the container.

4. Total the volume of water you poured into the material in the container.

5. Calculate porosity using the formula $\%$ porosity $=$ volume of water $x 100$ total volume

6. Repeat steps $1-5$ with the other two materials.

SUMMARY: At the end of the activity, students can compare data, hypothesize about the reasons for the different porosities of the three materials, and think about the significance of their findings. Students should find that different types of materials will hold different volumes of water depending on pore spaces and sorting of materials.

NOTE: The sand and pea-size gravel should have approximately the same porosity, with the sand/pea-size gravel mixture a smaller porosity. 


\section{Activity 3}

Unconfined Aquifer

PURPOSE: To learn about the water table by building and manipulating a ground-water model.

\section{Materials Needed:}

1. Plastic box ground-water model or large, clear bowl.

2. Pea-size gravel.

3. Grease pencil or nonpermanent marker.

4. Sufficient water to fill all group's models or bowls.

\section{PROCEDURE:}

1. Fill plastic box ground-water model or clear bowl $3 / 4$ full with pea-size gravel.

2. Slowly pour water into the bowl until a water line is seen.

3. Mark the "water table" on the side of the bowl (with broken lines - - - ) using a grease pencil or nonpermanent marker.

4. Dig a ditch from edge to edge across the diameter of the container.

5. Pour more water into the container until the ditch is one-half full.

6. Mark the new "water table" with a grease pencil (using a solid line) on the side of the container.

7. Discuss the connection between the water table and the water in the ditch.

SUMMARY: The water table in an aquifer is simply the top of the saturated zone. When the top of the saturated zone (water table) in the container rises above the ground surface, the ditch fills with water. Where this occurs in nature (intersection of the water table with the land surface) a pond, lake, wetland, spring, or stream is formed. 


\section{Activity 4}

Calculations

PURPOSE: To learn how to calculate percent porosity and permeability of sand, gravel, and a sand/gravel mixture.

\section{Materials Needed:}

1. Sufficient dry sand, pea-size gravel, and a sand/pea-size gravel mixture to fill all of the cups used by the students.

2. Six 295-mL (10-oz) paper cups for each group. (Use a pencil to punch five holes in the bottom of three cups.)

3. Three pieces of cheesecloth with the same diameter as the bottom of the cups.

4. One 100-mL (3.4-oz) graduated cylinder for each group.

5. Ruler with metric units.

6. 7.6 liters ( 2 gallons) of water.

PROCEDURE: (Porosity)

1. Measure and pour $100 \mathrm{~mL}$ ( $3.4 \mathrm{oz}$ ) of pea-size gravel, sand, and sand/pea-size gravel mixture into the paper cups without holes.

2. Measure and pour water over the pea-size gravel until the water is just barely covering the pea-size gravel.

3. Record the volume of water poured into the cup on a data sheet.

4. Compute the percent porosity as volume of water poured into cup $\times 100$ $100 \mathrm{~mL}$ of material

\section{REPEAT THIS PROCESS FOR ALL MATERIALS. BE SURE TO RECORD THE VOLUME OF} WATER POURED INTO THE CUP ON THE DATA SHEET.

\section{PROCEDURE: (Permeability)}

1. Place the three pieces of cheesecloth in the bottom of the three cups with holes.

2. Fill one cup $1 / 2$ full of dry sand, another cup $1 / 2$ full of dry pea-size gravel, and a third cup $1 / 2$ full of dry sand/pea-size gravel mixture.

3. Hold the cup over a container to collect water.

4. Add $100 \mathrm{~mL} \mathrm{(3.4} \mathrm{oz)} \mathrm{of} \mathrm{water} \mathrm{to} \mathrm{each} \mathrm{of} \mathrm{the} \mathrm{cups.}$

5. Measure the amount of water collected in the container in $\mathbf{1 5}$ seconds.

6. Calculate the rate of flow through each material.

$$
\text { Rate of flow }=\frac{\text { volume of water added to container } \mathrm{mL} \text { in cup }(\mathrm{mL})}{15 \text { seconds }}=\frac{\mathrm{mL}}{\mathrm{sec}}
$$

SUMMARY: Porosity percentage is a measure (ratio) of openings contained in a material, to the total volume of that material times 100 . Permeability is a measure of the ability of water to move through a material. 


\section{APPENDIX C \\ SELECTED REFERENCES}


The following selected references are included to supply you, the instructor, with sources for continued study on the topic of ground water. These selected references were reviewed and categorized by a team of teachers and curriculum-development specialists from around the Nation. The references are not intended to be an all-inclusive list, but are provided for informational purposes only.

$\mathrm{Y}$ is the code for Yes.

$\mathrm{N}$ is the code for No.

\section{Title: EXPLORING THE WATER WORLD}

Publisher: Regional Water Authority

Copyright: $\mathbf{N}$

Applicable Area: State: $Y \quad$ Region: $Y \quad$ National: $Y$

Type of Educational Material:

Curriculum materials: $\quad$ Y

Demonstrations: N

Projects, games: N

Y Activities: Y

Teachers Guide: $\quad Y$

Other materials: None

Student Guide:

$Y$
$Y$

Order From:

Name: $\quad$ Regional Water Authority

Address: $\quad 90$ Sargent Drive

City/State: New Haven, CT 06511-5966

Telephone: (203) 624-6671

Title: GROUND WATER PROTECTION CURRICULUM GUIDE

Publisher: Missouri Department of Natural Resources

Copyright: $\mathrm{N}$

Applicable Area: State: $Y \quad$ Region: $Y \quad$ National: $Y$

Type of Educational Material:

Curriculum materials: $\quad$ Y

Demonstrations:

Projects, games:

Activities:

Teachers Guide:

Student Guide:

$\mathbf{Y}$
$\mathbf{Y}$
$\mathbf{Y}$

Other materials: None

Order From:

Name: Missouri Department of Natural Resources

Address: $\quad$ P.O. Box 176

City/State: Jefferson City, MO 65102

Telephone: (314) 751-3443 
Title: GROUND WATER STUDIES

Publisher: Denver Earth Science Project

Copyright: $\mathbf{Y}$

Applicable Area: State: $\mathbf{Y} \quad$ Region: $Y \quad$ National: $Y$

Type of Educational Material:

Curriculum materials:

Demonstrations:

Projects, games:

$\mathbf{Y}$

Activities:

Teachers Guide:

Student Guide:

$\mathbf{Y}$
$\mathbf{Y}$
$\mathbf{Y}$

Other materials: None

Order From:

Name: $\quad$ Director, Denver Earth Science Project

Address: $\quad$ Office of Special Programs \& Continuing Education

Colorado School of Mines

City/State: Golden, CO 80401

Telephone: (303) 273-3494

Title: GROUNDWATER: A VITAL RESOURCE

Publisher: Tennessee Valley Authority

Copyright: $\mathrm{N}$

Applicable Area: State: Y Region: Y National: Y

Type of Educational Material:

Curriculum materials:

Demonstrations:

Projects, games:

Other materials: None

From:

Name: Tennessee Valley Authority

Address: Office of Natural Resources and Economic Development

City/State: Environmental/Energy Education Program

Telephone: unknown

Title: GROUNDWATER RESOURCES \& EDUCATIONAL ACTIVITIES FOR TEACHERS

(G R E A T)

Publisher: Iowa Department of Natural Resources

Copyright: $\mathrm{N}$

Applicable Area: State: N Region: N National: $\mathrm{Y}$

Type of Educational Material:

Curriculum materials:

Demonstrations:

Projects, games:

$\mathbf{Y}$

Activities:

N Teachers Guide: $\quad Y$

$\mathbf{Y}$

Y Student Guide: $\quad$ Y

Other materials: None

Order From:

Name: Conservation Education Center

Address: $\quad$ R.R. 1, Box 53

City/State: Guthrie Center, IA 50115

Telephone: unknown

Activities:

Teachers Guide:

Student Guide:
$\mathbf{Y}$

Y

$\mathbf{Y}$ 
Title: GROUNDWATER STUDY GUIDE

Publisher: Wisconsin Department of Natural Resources

Copyright: $\mathrm{N}$

Applicable Area: State: Y Region: Y National: Y

Type of Educational Material:

Curriculum materials:

Demonstrations:

Projects, games:

$\mathbf{Y}$

$\mathbf{Y}$

$\mathbf{Y}$
Activities:

Teachers Guide:

Student Guide:
$\mathbf{Y}$

$\mathbf{Y}$

Other materials: None

Order From:

Name: $\quad$ Environmental Education Specialist, Wisconsin DNR

Address: Box 7821

City/State: Madison, WI 63707

Telephone: unknown

Title: HOUSEHOLD TOXICS

Publisher: Municipality of Anchorage \& Anchorage School District

Copyright: Y

Applicable Area: State: $\mathbf{Y}$ Region: $Y \quad$ National: $Y$

Type of Educational Material:

Curriculum materials:

Demonstrations:

Projects, games:

Other materials: None

Region: $\mathbf{Y} \quad$ National: $\mathbf{Y}$

Order From:

Name: $\quad$ Science Center, Anchorage School District

Address: 2231 S. Bragan

City/State: Anchorage, AK 99507

Telephone: (907) 263-7161

Title: MAKING WAVES

Publisher: Nebraska Groundwater Foundation

Copyright: $Y$

Applicable Area: State: $\mathbf{Y}$ Region: $\mathbf{Y}$ National: $Y$

Type of Educational Material:

Curriculum materials:

Demonstrations:

N Activities:

Y Teachers Guide:

N Student Guide:

$\mathbf{Y}$

$\mathbf{Y}$

Projects, games:

Other materials: None

$\mathbf{Y}$

$\mathbf{Y}$

$\mathbf{Y}$

Activities:

Teachers Guide:

Student Guide:
Y

$\mathrm{N}$

$\mathbf{N}$

Order From:

Name: Nebraska Goundwater Foundation

Address: $\quad$ P.O. Box 22558

City/State: Lincoln, NE 68542-2558

Telephone: (800) 858-4844 
Title: SANDCASTLE MOATS AND PETUNIA BED HOLES

Publisher: Virginia Water Resources Research Center

Copyright: $\mathbf{N}$

Applicable Area: State: $\mathbf{Y}$ Region: $\mathbf{Y}$ National: $\mathbf{N}$

Type of Educational Material:

Curriculum materials:

Demonstrations:

Projects, games:

\author{
Region: $Y$ un National: N
}

Other materials: Worksheets

$\begin{array}{lll}\mathbf{Y} & \text { Activities: } & \mathbf{Y} \\ \mathbf{Y} & \text { Teachers Guide: } & \mathbf{Y} \\ \mathbf{N} & \text { Student Guide: } & \mathbf{Y}\end{array}$

Order From:

Name: Virginia Water Resources Research Center

Address: $\quad 617$ North Main Street

City/State: Blackburg, VA 24060-3397

Telephone: (703) 961-5624

Title: STOP, LOOK AND LEARN ABOUT OUR NATURAL WORLD

Publisher: Nebraska Natural Resources Commission

Copyright: $\mathrm{N}$

Applicable Area: State: Y Region: Y National: Y

Type of Educational Material:

Curriculum materials: $\quad$ Y

Demonstrations: $\quad \mathbf{Y}$

Projects, games: $\quad$ Y

Other materials: Worksheets

Order From:

Name: Nebraska Natural Resources Commission

Address: $\quad 301$ Centennial Mall South, P.O. Box 94875

City/State: Lincoln, NE 68509

Telephone: (402) 471-2081

Title: WATER EDUCATION

Publisher: International Office for Water Education

Copyright: Y

Applicable Area: State: $\mathbf{Y}$ Region: $\mathbf{Y} \quad$ National: $\mathbf{Y}$

Type of Educational Material:

$\begin{array}{llll}\text { Curriculum materials: } & \text { N } & \text { Activities: } & \text { Y } \\ \text { Demonstrations: } & \text { N } & \text { Teachers Guide: } & \text { N } \\ \text { Projects, games: } & \text { N } & \text { Student Guide: } & \text { Y }\end{array}$

Other materials: None

Order From:

Name: International Office for Water Education

Address: UMC 82, Utah Water Research Laboratory

City/State: Logan, UT 84322

Telephone: unknown 